\title{
Factors determining the distribution of foraminiferal assemblages in Port Joinville Harbor (Ile d'Yeu, France): the influence of pollution
}

\author{
Jean-Pierre Debenay ${ }^{\mathrm{a}^{*}}$, Erica Tsakiridis ${ }^{\mathrm{b} 1}$, René Soulard ${ }^{\mathrm{c}}$ and Hubert Grossel ${ }^{\mathrm{d}}$ \\ a'Département de Géologie, Université d'Angers, UPRES EA 2644, 2 Bd Lavoisier, 49045, Angers cedex, France \\ bLÉBIM, Ker Châlon, 85350, Ile d'Yeu, France \\ 'DDE de la Vendée, Service maritime, CQEL, Rue Gay Lussac, 85100 Les Sables, d'Olonne, France \\ ${ }^{d}$ Ifremer, rue de l'Îe d'Yeu, BP 21105, 44311, Nantes cedex, France \\ ${ }^{1}$ Present address: Dipartimento di Scienze Geologiche, Ambientali e Marine, Via E. Weiss 2, 34127 Trieste, Italia \\ *: Corresponding author : Fax: +33-4173-5352 debenay@univ-angers.fr
}

\begin{abstract}
Port Joinville harbor is located on an island. Thus, it receives only a few freshwater inputs, contrary to most of the areas where the influence of pollution on foraminiferal assemblages has been studied. The pollution in the harbor mainly results from the boats, including cleaning, painting and outfall of oil and motor-fuel.
\end{abstract}

A total of 59 sediment samples was collected at three sampling periods (November-December 1997, May 1998 and September 1998). These samplings were supplemented by the study of algal flora and macrobenthos and by the study of water circulation by means of six stations where water was collected every hour during a tide cycle. Contaminants were analyzed in the last series of 17 samples. Total assemblages were used for this study. This choice is explained and discussed.

This study shows that the main factor that determines the distribution of foraminiferal species in Port Joinville harbor is the geographical position. The correlation that occurs between heavy metals and the silt and clay fraction makes it difficult to determine whether sediment characteristics or pollution have the stronger influence on foraminiferal assemblages, except in areas heavily affected by pollution. Polluted sediments, near the careening areas, are indicated by the tolerant pioneer species Cribroelphidium excavatum and Haynesina germanica. The growth of epiphytic species depends on the presence of algae and their distribution may be favored by local conditions such as the constant immersion of the supports in the wet dock.

Keywords: Foraminifera; Bioindicators; Pollution; harbor; Atlantic; France 


\section{Introduction}

In the last few years many studies dealing with benthic foraminifera as biomarkers or bioindicators of coastal pollution have been carried out. They have often focused on areas exposed to direct pollution sources such as industrial, agricultural and domestic waste, paper processing, oil pollution or heavy metal contamination. Their main purpose is to quantify the effects of pollution upon foraminiferal distribution and morphology (e.g., Bandy et al., 1965; Vénec-Peyré, 1981; Setty, 1982; Bhalla and Nigam, 1986; Alve and Nagy, 1988; Alve, 1991, 1995; Sharifi et al., 1991; Banerji, 1992; Schafer et al., 1995; Yanko et al., 1998; review in Yanko et al., 1999). However, only a few studies consider specifically polluted harbors (Murray, 1968; Rouvillois, 1972; Naidu et al., 1985; Debenay et al., 1997) and only a few studies have been carried out on the coastal environments of the Atlantic coast of France (e.g., Dupeuble, 1963; Dupeuble et al., 1971; Le Campion, 1968, 1970; Rouvillois, 1967; Rosset-Moulinier, 1972; VénecPeyré, 1982; Debenay, 1978; Casamajor and Debenay, 1995; Redois and Debenay, 1996; Goubert, 1997).

The study area is Port Joinville harbor (Ile d'Yeu, France). This paper is intended to identify the factors controlling the distribution of foraminifer assemblages, in relation to the intensity of marine influence, and to anthropogenic impact on various parts of the harbor.

\section{Environmental setting}

Ile d'Yeu is located over $20 \mathrm{~km}$ off the coast of Vendée (France). Having a NW-SE extension, it is $10 \mathrm{~km}$ long and $4 \mathrm{~km}$ wide (fig. 1). The northeastern coast, where the harbor is located, is protected from the influence of the open sea and is characterized by a reduced wave intensity. The tides are semi diurnal and mesotidal with a mean range of about $4 \mathrm{~m}$. Contrary to most other harbors, Port Joinville harbor is not located in an estuarine zone and thereby receives very few freshwater inputs. These features provide particular environmental conditions and pollution that results mainly from fishing activities and domestic wastes from the pleasure boats (organic pollution), careening and painting of the boats, and fuel leakage (chemical pollution) is not associated with a significant freshwater input. There are three careening areas that are direct sources of pollution (fig. 2).

The harbor occupies an area of about $0.1 \mathrm{~km}^{2}$ and is made up of a series of five basins that are, from east to west: a marina that occupies the largest basin (1), a wet dock (2), two basins for the ferryboats and the fishing-boats, separated by a wharf where the ferry-boats moor (3 and 4), basin 4 being used also for pleasure boats, and a basin dedicated to the fishing activities (5) (fig. 2). The wet dock opens about 2 hours before high tide and closes about 2 hours after. In 1996, a new portion was added to the marina in order to accommodate the increasing number of pleasure boats (fig. 2). The depth of about $2.5 \mathrm{~m}$ below lower low tide near the entrance decreases towards the innermost parts of the basins. The average depth is about $1.5 \mathrm{~m}$ below lower low tide. As no hydrologic study had been performed in the harbor before, the water circulation is described in this paper on the basis of measurements made during this study.

The main economic resources of the island depend on fishing and tourism activities. Fishing is still the main activity, the flotilla of the island being composed of about 90 boats for local or coastal fishing and 30 ocean-going vessels specialized in catching noble fish species. The stream of tourists transported by ferryboat is very strong from May to October, reaching a maximum in July and August, when about 2,000 people 
visit the island every day. During this period, about 450 pleasure boats are moored in the marina.

\section{Material and methods}

Sediment samplings were repeated three times, in November-December 1997, May 1998 and September 1998. Bottom samples were collected from 21 selected sites in November-December and May and from 17 sites in September (fig. 3). For comparison, a sample of muddy sand was also collected at the lower limit of the intertidal area, about $200 \mathrm{~m}$ to the east of the harbor. A grab sampler was used that collects sediment over a surface of about $400 \mathrm{~cm}^{2}$. This grab sampler has been specially constructed to hermetically close, to prevent the surface of the sediment from being washed away during collection. In the boat, the grab is carefully opened in a container where the sediment is deposited in its initial position. Generally, a diatom film covers the surface of the sediment and indicates the absence of disturbance during collection. The samples collected in November-December 1997 were used for a thorough study of the foraminiferal assemblages. The following samples were used to study the seasonal variations of these assemblages, the last ones being also used for geochemical analyses of the sediment. Tributyltin (TBT) and triphenyltin (TPhT) analyses were carried out in the Ifremer laboratory. The measures of total organic carbon (TOC) content and of the content of $\mathrm{Al}, \mathrm{As}, \mathrm{Cd}, \mathrm{Cr}, \mathrm{Cu}, \mathrm{Hg}, \mathrm{Ni}, \mathrm{Pb}, \mathrm{Zn}$, polynuclear aromatic hydrocarbons (PAHs) and polychlorinated biphenyls (PCBs) were carried out at the Institut Pasteur (Lille, France). The microbiological analyses (fecal coliforms and fecal streptococci) were carried out in the laboratory of the Département de Vendée.

The uppermost layer of the sediment $(0.5$ to $1 \mathrm{~cm})$ was scraped off and kept in alcohol mixed with sea water for the study of foraminifers. A subsample of $50 \mathrm{~cm}^{3}$, corresponding to a surface of about $75 \mathrm{~cm}^{2}$ was taken from the original sample and washed through 315, 125 and $50 \mu \mathrm{m}$ sieves. Only very rare tests were found in the fraction coarser than $315 \mu \mathrm{m}$. The 50-315 $\mu \mathrm{m}$ fraction used for the foraminiferal study was stained with Rose Bengal to help recognize the living individuals and a flotation method using carbon tetrachloride $\left(\mathrm{CCl}_{4}\right)$ was applied to concentrate the tests. More than 300 individuals were identified and counted from the total fauna (living and dead) for each sample. The Loeblich and Tappan classification (1988) was used. Grain size analyses were carried out to establish the percentage of silt and clay (fraction $<63 \mu \mathrm{m}$ ) and sand fractions $(2 \mathrm{~mm}-63 \mu \mathrm{m})$. When present, the coarser fraction $(>2 \mathrm{~mm})$ is made up of a few fragments of molluscs and/or gravels.

In order to determine the characteristics of the water, six fixed stations were selected for a 12 hour monitoring period: stations a-b in the fishery basin, c-d in the wet dock and e-f in the marina (fig. 3). The monitoring in stations a and b was carried out on May 19, 1998 (high tide 11:38, low tide 17:20, neap tide). In stations c and d, it was carried out on May 14, 1998 (low tide 13:13, high tide 19:11, intermediate tide), and in stations e and f on May 21, 1998 (high tide 14:09, low tide 19:44, opening of the tide gate 11:33, closing of the tide gate 15:55). Bottom water was collected by means of a bottle and physicochemical parameters were measured following the tidal cycles: depth with a rigid gauge; dissolved oxygen by means of an oximeter (WTW Oxi 197, probe WTW CellOx 325, precision $0.01 \mathrm{mg} \mathrm{l-1);} \mathrm{pH}$ with a $\mathrm{pH}-$ meter (Hanna HI9625, precision 0.01); salinity with a conductimeter salinometer (WTW LF325, probe WTW Tetracon 325, precision $0.1 \mathrm{~g} \mathrm{l}^{-1}$ ); and turbidity with a turbidimeter (Orbeco-Hellige 966, precision $2 \%$ ). The values were compared with those of the open sea water collected outside the harbor (dissolved oxygen: $10.17 \mathrm{mg} \mathrm{l}-1, \mathrm{pH}$ : 8.17, salinity: $34.2 \mathrm{~g} \mathrm{l}^{-1}$ ). To complete the study, seaweeds were collected and identified from eight stations in July 
1998 and from the same stations in September 1998 (fig. 3, stations A to H). Another seaweed sampling was made in May 1997 for the study of epiphytic foraminiferal species (fig. 3).

Species occurring in more than $95 \%$ of one series of samples and of more than $50 \%$ in the other two were selected for statistical analyses since, according to Culver and Buzas (1981), the use of commonly occurring species can explain the characteristics of an area as well or better than using all the species. The relative abundance of the selected species was treated in a Q mode and R mode factor analysis, and a Q-mode hierarchical analysis based on euclidian distance correlation coefficients was carried out using Statlab for Macintosh (SLP infoware). An analysis of the correlations between the relative abundance of these species and the geochemical-sedimentological parameters was carried out in September 1998 using Stat View for Macintosh (Abacus Concepts Inc). Among the species selected for statistical analyses, those that have a relative abundance of more than $10 \%$ in at least one sample have been selected for a detailed distribution study. Except for Textularia truncata, living individuals of these species were collected in the harbor.

\section{Results}

\subsection{Hydrological data (fig. 4)}

\section{Salinity}

During rainy periods, the salinity is slightly lower in the harbor than in the open sea, owing to various freshwater inputs. In May, it was about 33.6 in the harbor and 34.2 in the open sea. During the summer, it is almost the same in the harbor as in the sea water. In July, it was about 35. No salinity stratification was noticed inside the harbor.

\section{Temperature}

The temperature of the water increases in the afternoon as a result of solar warming. It varies between 16 and $17{ }^{\circ} \mathrm{C}$ in May and between 16.5 and $18{ }^{\circ} \mathrm{C}$ in July. An average difference of about $1{ }^{\circ} \mathrm{C}$ was observed between surface and bottom temperatures, a slight thermocline occurring during flood tide when the cooler sea water penetrates the harbor near the bottom. At the beginning of the flood tide, the temperature decreases abruptly in the marina. This decrease is less marked in the other zones.

\section{Dissolved oxygen}

In May, dissolved oxygen content varied from 8.3 to $10.6 \mathrm{mg} \mathrm{l}^{-1}$. The lowest values were measured in the inner part of the marina. During the afternoon, the oxygen concentration increased as a result of the photosynthetic activity of the algae.

\section{$p H$}

The $\mathrm{pH}$ is the lowest in the marina (8.04 to 8.19) and the highest in the wet dock (8.29 to 8.35). The general trend is towards an increase in the $\mathrm{pH}$ values during the afternoon as a result of the photosynthetic activity. However, it decreases slightly during the flood tide in the fishing basin, where the $\mathrm{pH}$ is higher than the $\mathrm{pH}$ of the sea. In the same way, the $\mathrm{pH}$ decreases in the wet dock after the opening of the tide gate (fig. 5).

\section{Turbidity}

The turbidity is low in all the stations $(<5)$ except at low tide in the fishing basin (station a). This probably results from the fact that at low tide the sediments can be 
brought into suspension by the boats striking the bottom sediments, or by their propeller stirring the water.

\section{2. Seaweeds}

Sixty-five species of algae were identified in the harbor, belonging to the Chlorophyta (green algae), Phaeophyta (brown algae) and Rhodophyta (red algae). Fifty-six of these species are present in the entrance of the harbor (stations A, B and C; fig. 3) including 33 species of red algae, 15 of brown algae and 8 of green algae. Well inside the harbor, the species richness decreases drastically, and the brown and green algae become dominant. Only 9 species of red algae, 7 of brown algae and 7 of green algae were present at station $\mathrm{H}$. Stations $\mathrm{D}$ and $\mathrm{F}$ located in the innermost part of the harbor have very poor algal floras with only 2 species of red algae (Mastocarpus stellatus and Porphyra umbilicalis), 7 of brown algae and 6 of green algae, mainly the Enteromorpha and Ulva species. Stations E and G present particular characteristics. Station E, located in a basin dedicated to ferryboats, is richer in red algae (6 species) and poorer in brown algae (2 species). At station G, located on a recently constructed floating wharf, algal colonization was still beginning with only 9 species. However, owing to the constant submersion of the support, infratidal species were present, such as Chladophora pellucida, Dictyopteris membranacea and Himanthalia elongata. Some of the species have a seasonal cycle of development. No detailed study was carried out in the wet dock, but observations of the wharves show a great amount of green algae, specially inside the tires attached along the wharves for the protection of boats.

\section{3. Sediments}

Bottom sediments are mainly mud or muddy sands with an average of $66 \%$ of the silt and clay fraction. However, tidal currents and water stirring due to the circulation of numerous fishing boats and ferryboats lead to a sandy fraction of about $100 \%$ in the harbor entrance and $50 \%$ in the central part of the harbor (fig. 6). The silt and clay content is the highest ( $>65 \%)$ in the marina and in the inner part of the basins. In the recently constructed extension of the marina, sediments are very fine, and form a light brown coat, 10 to $20 \mathrm{~cm}$ thick, over the rocky substrate. Elsewhere, the oxidized layer is about 1 to $2 \mathrm{~cm}$ thick. The organic carbon content is low, except in basins 2 and 3, and in the inner parts of basins 4 and 5 where TOC composes more than $10 \%$ of the dry sediment (table 1).

Except in the marina, the As content of the sediments is close to the levels reported from pre-industrial sediments of the Humber estuary (Grant and Middleton, 1990; table 3) showing a limited anthropogenic impact. It is high only in the new extension of the marina (more than $100 \mathrm{mg} \mathrm{kg}^{-1}$; table 1). This arsenic may originate from quartz veins of the magmatic rocks blown up during the digging of the basin. Such veins may include arsenopyrite, a widely distributed mineral that is the most prevalent source of arsenic. A relatively high content of copper exists in all the harbor except the entrance channel, with more than $50 \mathrm{mg} \mathrm{kg-1}$. The highest values of $\mathrm{Cu}$ were found in the wet dock (stations 17 and 18) and near the main careening area (station 13) with $1100 \mathrm{mg} \mathrm{kg-1}$ (fig. 7). The same stations experience high contamination by zinc and lead. Pollution by TBT is strong in stations 18 and 13, near careening areas used for big fishing boats, with $23,500 \mu \mathrm{g} \mathrm{kg}-1$ and 54,700 $\mu \mathrm{g} \mathrm{kg}-1$ respectively, and to a smaller extent in station 7 with 6,280 $\mu \mathrm{g} \mathrm{kg-1} \mathrm{(table} \mathrm{1).}$

The correlation matrix shows that a strong correlation occurs between zinc, copper and lead, as well as between nickel and chromium (table 2). Regression diagrams (fig. 7) show that correlations also exist between arsenic and cadmium and between chromium and copper, even if they do not appear on the matrix. These diagrams bring 
out the particular characteristics of the marina (enrichment in As), of the wet dock (enrichment in $\mathrm{Cu}$ and $\mathrm{Zn}$ ) and of sample 13 collected near the main careening area (strong enrichment in $\mathrm{Cu}$ and $\mathrm{Zn}$ ). Correlations were also evidence between heavy metals and

Fecal coliforms and fecal streptococci have the highest concentration in the fishing basin (stations 9 and 10) with up to 750,000 streptococci per gram and in station 15 which is near the area where fishing boats discharge their fish for the auction hall (table 1). Thus it is possible to infer that most of these bacteria originate from the guts of the fish. However, their relatively high concentration in the marina (stations 6 and 7) indicates that human contamination probably occurs as well.

\section{5. Foraminifera}

\section{General features}

The thorough study of the total assemblages collected in November-December 1997, completed by examination of the later samplings, led to the identification of 179 species including 124 hyaline, 23 agglutinated and 32 porcellaneous ones (appendix 1, 2, 3). Since the species living on the french coast have rarely been figured, the main species are shown in plates 1 to 6 . The number of individuals per $50 \mathrm{~cm}^{3}$ of sediment ranges between 2,000 and 180,000 with the highest values in May 1998 (8,000 to 180,000) and the lowest in September 1998 (2,000 to 80,000). During the three sampling periods, the maximum density was observed near the entrance and in the central part of the harbor; the minimum ones occurred in the wet dock and in the marina (appendix 1-3 and fig. 8). The density was particularly low in the marina in September, at the end of the tourist season. The number of species in each sample ranged from 29 to 58. It was slightly lower in November-December 1997 (average $=40$ ) than in May and September 1998 (average $=47$ ). No relation could be observed between the number of species and the position of the sample (appendix 1-3).

The limited number of living specimens did not allow a relevant study of their distribution and the following distribution study concerns total assemblages, including living and dead individuals. However, the presence of living specimens shows that these species may live in the harbor and that their empty tests are probably autochthonous.

\section{Living specimens}

Only a few living specimens have been collected. Most of them live in the marina and belong to Aubignyna planidorso, Bolivina pseudoplicata, Bolivina sp. 1, Brizalina spathulata, Brizalina variabilis, Bulimina elegans, Cassidulina crassa, Cribroelphidium magellanicum, Haynesina depressula, Haynesina germanica, Quinqueloculina sp. and Reophax nana. In the central part of the harbor, the living species are B.spathulata, $B$. variabilis, B. elegans, Cribroelphidium excavatum, Gavelinopsis praegeri, $H$. depressula, $H$. germanica, $R$. nana and Stainforthia fusiformis. The only noticeable presence of living specimens was in station 6 in September, with 240 living $C$. excavatum in the fraction $125-350 \mu \mathrm{m}$ of $50 \mathrm{~cm}^{3}$ of sediment (about $80 \%$ of the total assemblage in this fraction).

The epiphytic species collected on the algae are dominated by Elphidium pulvereum, Neoconorbina spp., Rosalina spp. and Lobatula lobatula and are present everywhere in the harbor. Spirillina vivipara also has a wide distribution but is absent from the wet dock. Gavelinopsis praegeri, Bolivina spp., Miliolinella subrotunda, Patellina corrugata, Quinqueloculina sp. and Palliolatella orbinyana are scarce and randomly distributed. Ammonia beccarii, Adelosina sp., Massilina seccans, Elphidium crispum 
and Planorbulina mediterranensis are present near the entrance of the harbor in an area under marine influence. Epiphytic species were found on red algae, mainly Gigartina acicularis and on green algae, mainly Cladophora rupestris, but never on brown algae.

\section{Distribution of the species}

Bolivina pseudoplicata and B. variabilis have a somewhat irregular distribution. The only inconspicuous and irregular tendency is a slightly higher relative abundance in the marina and in the inner parts of the other basins, except in the wet dock. This tendency is much more obvious for Bolivina sp.1 or when considering all the bolivinids together (fig. 9). In september, bolivinids show a general positive correlation with the silt and clay content of the sediment (fig. 10) with an enrichment in bolivinids in basin 5, dedicated to the fishing activities, in the neighbouring basin 4 (fishing and pleasure boats), and in the marina. Sample 1, near the apperture, and the innermost sample 7, near the carrening area of the marina, have a low relative abundance of bolivinids.

Bulimina elegans has a very irregular distribution. It is rare, except in the innermost part of the marina where its relative abundance was relatively high in NovemberDecember 1997, reaching 15.8 \%. Its relative abundance decreased considerably in September 1998 (fig. 11). Cribroelphidium excavatum is irregularly distributed. However, its relative abundance was the highest in the marina in September when the population density was the lowest (fig. 11). High percentages of this species are also present in the wet dock, near the careening area and in the fishing basin (basin 5). By contrast, it is not very high near the main careening zone. Elphidium pulvereum has a very low relative abundance, generally less than $2 \%$, except in the wet dock where it always constitutes more than $5 \%$ of the microfauna (fig. 11). Gavelinopsis praegeri occurs throughout the harbor in relative abundance higher than $10 \%$ except in the inner zones of the basins (fig. 11). H. germanica is present in all the sites but is always very rare (average value $1.5 \%$ ) except in the inner part of the marina (17\%) and in the wet dock (14.6 \%) in November-December 1997 (fig. 11).

The distribution of $P$. mediterranensis and L. lobatula, grouped together because they have the same epifaunal style of life, clearly shows the role of marine influence in their distribution (fig. 11). Their relative abundance decreases from more than $20 \%$ in the central part of the harbor to less than $10 \%$ in the wet dock and in the innermost part of the marina. T. truncata shows values ranging from more than $8 \%$ in the central area to less than $3 \%$ in the innermost areas (fig. 11). Owing to the algae growing on the rocky shore, epiphytic species are dominant in the coastal sample (appendix 3).

\section{Statistical analyses}

The correlation analysis shows that the population density is negatively correlated with all the analyzed contaminants (table 2). However, the correlation with $\mathrm{Al}$ is very low, which is in agreement with the toxicity of elements as classified by Wood (1974). Moreover, Al measured by these analyses mainly indicates the presence of clay minerals. It is probably for this reason that a noticeably positive correlation exists between $\mathrm{Al}$ and $B$. pseudoplicata and Bolivina sp.1, that live in muddy sediment. Some species show a strong correlation with one or several contaminants (table 2). The most remarkable are: $C$. excavatum and $C$. magellanicum positively correlated with As; $E$. pulvereum positively correlated with $\mathrm{Pb}, \mathrm{Zn}$, and $\mathrm{Cr}$; $B$. variabilis positively correlated with $\mathrm{Cd}$; H. germanica positively correlated with $\mathrm{Pb}$; Fissurina lucida positively correlated with Hg; Lepidodeuterammina ochracea positively correlated with Cd. L. lobatula and P. mediterrannensis are negatively correlated with all the contaminants with the highest values for $\mathrm{Ni}, \mathrm{Cd}$ and $\mathrm{Cr}$. Heavy metals are all positively correlated with the silt and clay fraction (table 2). This correlation is very strong for $\mathrm{Cr}$ and $\mathrm{Ni}$, but 
even if values are lower for other pollutants, regression diagrams show that correlations also exist, except for a few peculiar samples, as shown for arsenic (fig. 7).

A positive correlation exists between $\mathrm{PAH}$ and Bolivina difformis, B. pseudoplicata and $C$. magellanicum; between PCB and $H$. germanica. A correlation also exists between TBT and TPhT and Bolivina sp.1 and L. ochracea. However, these correlations have been determined with a few samples (14 for PAH and PCB, 9 for TBT and TPhT) and have a limited significance.

The Q mode hierarchical classification allowed the distinction of five clusters in November-December 1997, four in May 1998 and three in September 1998 (fig. 12). The mapping of these clusters shows the same distribution during the three sampling periods with a zonation from the central part of the harbor towards the innermost parts of the basins. The only exception was one sample from the wet dock in NovemberDecember 1997.

The $\mathrm{R}$ mode and $\mathrm{Q}$ mode factor analyses carried out for the taxa from samples collected in September consider only the first three factors that explain about $73 \%$ of the variance (fig. 13 and 14). On the first plane 1-2, the three groups of samples determined by the Q mode hierarchical classification are distributed according to their position in the harbor (fig. 13). The first factor corresponds to the changeover from the central harbor towards the innermost parts of the basins near careening areas, and the second factor corresponds to the changeover from the areas under direct oceanic influence towards the central part of the harbor. Thus, the main factors determining the distribution of the foraminiferal species are related to the geographical position of the samples, except for stations 7 and 18 that may be strongly influenced by the pollution resulting from careening activities.

As previously shown on the distribution maps, $P$. mediterranensis and, to a smaller extent, L. lobatula are characteristic of a strong marine influence. Apart from Al and $\mathrm{Hg}$, all the pollutants analyzed as supplementary variables are located towards the positive values of axis 1 . The species also related to positive values of axis 1 are $H$. germanica, E. pulvereum, C. excavatum and C. magellanicum. The associated samples are samples 7 and 18, located near careaning areas, and samples 17 and 6, not far from the previous ones, in the marina and in the wet dock. Axis 3 discriminates between two types of pollutants (fig. 14): arsenic towards positive values and lead, copper and zinc towards negative values. The other pollutants, as well as the silt and clay fraction content, do not show strong correlation with this factor. The species that are positively correlated to factor 3 are $C$. magellanicum and to a smaller extent $C$. excavatum, $F$. lucida and Bolivina sp. 1. They are associated with samples 6 and 7. The species negatively correlated to this factor are E. pulvereum and to a smaller extent, Bulimina elegans, Rosalina globularis, Cribrononion gerthi, Angulogenerina angulosa and $B$. difformis. They are associated with samples 17 and 18. Thus, foraminiferal assemblages are the most affected by pollution in the marina and in the wet dock. Their response is different when nature of pollution changes.

\section{Discussion}

\section{1. The use of total assemblages}

Owing to considerable changes during life cycles, a dramatic bias may be introduced by using living assemblages for environmental studies, except if a monitoring of at least one year is carried out. Therefore, since one year monitoring is often impossible in environmental studies, some authors consider that total assemblages are preferable to living ones for environmental studies (eg., Scott and Medioli, 1980; Hayward, 1982). 
Moreover, using total assemblages smoothes small scale variability and allows epiphytic microfauna to be taken into account, as only dead specimens of epiphytic species can be present in the sediment. On the other hand, living specimens are generally detected by Rose Bengal staining, but the efficiency of this method is still debated since cytoplasm may be preserved in the test several weeks after death (eg., Boltovskoy and Lena, 1970; Cann and Dekker, 1981). Using total assemblages is a way to circumvent this problem. However, total assemblages may include allochthonous specimens and Murray (1982, 1984, 1986) and Alve and Murray (1994) pointed out the bias that may result from postmortem transport.

In Port Joinville harbor, three sampling periods were not sufficient to take into account the life cycles of the different species. Thus we decided to use total assemblages. Nevertheless, in order to indicate the potentially autochthonous species, we give a list of species living in the harbor, either infaunal epifaunal or epiphytic. A list of species found in a coastal sample near the entrance of the harbor is also provided, since these species may be transported into the outer and central parts of the harbor, being there allochthonous. In the inner part of the basins, species such as $C$. excavatum and $H$. germanica and the living bolivinids that are very rare outside are certainly autochthonous.

Sedimentation rates may be very high in harbors, making necessary periodical dredging. In Port Joinville harbor, located far from the coast, it is relatively low, less than $5 \mathrm{~cm}$ per year. Thus, the superficial $1 \mathrm{~cm}$ of sediment scraped off for this study corresponds to a few months of sedimentation and therefore, total assemblages included in this sediment obviously change with season.

Of course, only live specimens are affected by pollution and one can wonder whether total or dead assemblages can really be used as indicators of pollution. However, dead assemblages are constituted, at least for a great part, by the accumulation of autochthonous specimens and are therefore also affected by pollution (even if the signal is somewhat distorted by the input of allochthonous specimens). As a result, total assemblages grouping living and dead assemblages are themselves affected by pollution, and thus may be used as indicators of pollution. As a comparison, it must be pointed out that diatom indexes, currently used for biomonitoring of European rivers, are based on total assemblages (e.g., Coste and Lenoir, 1996).

\section{2. Pollution of the sediments}

Contamination levels in Port Joinville harbor can be compared with the reference values established by the French GEODE program, i.e., the medians of heavy metal and PCB concentrations in the sediments of the major French harbors (Anonymous, 1996). Sediment contents of $\mathrm{Cr}, \mathrm{Hg}, \mathrm{Ni}$ and PCB are lower than the GEODE medians in all the stations of Port Joinville harbor (table 3). Cd level is slightly higher in only one station. However, it is higher than $1 \mathrm{mg} \mathrm{kg}^{-1}$ in five samples, which is relatively high since Cossa and Lassus (1989) reported only eight coastal sites in France where Cd concentration exceeded this value. The strongest contaminations, by comparison with the GEODE medians, result from $\mathrm{Cu}$ almost everywhere, $\mathrm{Zn}$ and $\mathrm{Pb}$ near the careening areas and As in the marina. Nevertheless, As concentrations in Port Joinville harbor are relatively low when compared with highly contaminated estuaries such as the lower estuary of the Rhine River with 1,200 mg kg-1 (Groot and Allersma, 1976) and the Restronguet Creek with 2,037 mg kg-1 (Langston, 1984). Comparison with the levels reported from pre-industrial sediments of the Humber estuary confirms the pollution by $\mathrm{Cu}, \mathrm{Pb}$ and $\mathrm{Zn}$, even if these values are relatively low when compared with highly polluted areas such as the Bilbao estuary (Cearreta et al., 2000; table 3). 
TBT levels are very high near careening areas. The same observations have been reported in other harbor where a marked difference has also been reported between the harbor itself and the adjacent areas. For example: 840 to 21,300 $\mu \mathrm{g} \mathrm{kg}-1$ in Brest harbor but only 2 to $197 \mu \mathrm{g} \mathrm{kg}-1$ off the harbor (Michel and Averty, 1995); 240 to $865 \mu \mathrm{gg}$ k-1 in the channel of a marina near Ré Island (Atlantic coast of France), and 2 to $17 \mu \mathrm{g} \mathrm{kg-1}$ in the adjacent areas (Alzieu and Michel, 1998). In San Diego Bay, Stang and Seligman (1986) noted higher TBT concentration near anchoring areas and maximum concentration near careening areas.

Pollutants are not necessarily bioavailable, even when they are present in the sediment with relatively high concentrations. In a harbor located in an estuarine zone, heavy metal compounds react to the change in salinity and metals are often desorbed from the clay mineral, increasing their bioavailability (Groot et al., 1976). This phenomenum does not occur in Port Joinville harbor where an almost stable salinity prevails. The relatively weak impact of heavy metals on the foraminiferal assemblages, except near the careening areas, may result from their reduced bioavailability.

\section{3. Effect of contaminants on the assemblages}

$\mathrm{Cu}$, that is responsible for the most widely distributed contamination in Port Joinville harbor, has been shown to have a negative impact on macrobiotic diversity when sediment concentration exceeds about 200 ppm (Rygg, 1985 in Alve and Olsgard, 1999), and a significant effect on meiofauna when Cu-concentration exceeds 500 ppm (Austen and others, 1994). Colonization experiments carried out by Alve and Olsgard (1999) showed that the opportunistic foraminifera S. fusiformis was dominant but it developed an increasingly patchy distribution pattern when $\mathrm{Cu}$-content increased. In Port Joinville harbor, only station 13 has a Cu concentration over 500 ppm. This station does not show any particular characteristics, except a higher proportion of $B$. pseudoplicata in September.

The decrease in assemblage density observed in September in the marina probably results from the domestic waste produced by the pleasure boats. It causes a noticeable source of pollution during summer, when the contaminant input is maximum.

Port Joinville harbor makes it possible to study the effect of pollution independently from the effect of fresh waters. Sewage discharge is often reported to cause an increase in agglutinated taxa (eg. Watkins, 1961; Bandy and others, 1964; Schaffer and Cole, 1974; Patterson, 1990; Alve 1993). Clark (1971) attributed the increased abundance of Eggerella advena to increased nutrient supply. However, Blais-Stevens and Patterson (1998) indicate that some biofacies such as Eggerella advena and Miliammina fusca Biofacies probably reflect brackish water conditions near sewage outfall more than contamination. Moreover, the agglutinated taxa present near sewage outfall are generally tolerant to brackish waters (Murray, 1991), which confirms that the fresh water discharged by sewage outfall probably has a strong impact on foraminiferal assemblages (Debenay and others, 2000). Thus, it is often quite difficult to discriminate between the impact of freshwater and the impact of pollutants in areas of sewage discharge. Port Joinville harbor shows that despite a noticeable pollution in the inner parts of the basins, including waste water from pleasure boats, calcareous species are dominant and only a few agglutinated species are present, even near the pollution sources. The same observations were reported from La Turballe harbor (Brittany, France) that also receives a limited fresh water input (Debenay et al., 1997).

The low diversity and density of living specimens compared to the dead assemblages can be explained by the cumulative contributions through time of rare short-lived species. A postmortem transport of tests would also be possible. However, this 
transport is not likely in the innermost zones that are characterized by muddy sediments and by low current action. Limited transport from the ocean is attested to by the occurrence of rare specimens of species like Uvigerina peregrina and Wiesnerella auriculata and of rare planktonic foraminifers. Transport is probably more active in the central part of the harbor, owing to the stirring of the water by fishing boats and by ferryboats.

\section{4. The resistant pioneer species $\mathrm{C}$. excavatum and $\mathrm{H}$. germanica}

Cribroelphidium excavatum is often considered as very tolerant to most kinds of contaminants. It is a motile species changing from epifaunal to infaunal habitats and highly adaptable to changes in food availability and/or changing environmental conditions (Linke and Lutze, 1993). It may be associated with Eggerella advena in the northwest Atlantic or Eggerelloides scabrus in the northeast Atlantic (eg. Schafer 1973 [C. excavatum as E. incertum clavatum]; Bates and Spencer, 1979; Sharifi and others, 1991; Alve and Nagy, 1986; Alve, 1995), with Ammotium cassis and Ammonia beccarii in polluted Swedish estuaries (Olsson et al., 1973) or with H. germanica and A. beccari in Southampton Water (Sharifi and others, 1991). In the former case, C. excavatum became dominant in areas previously dominated by $A$. beccarii after they were subjected to pollution (maximum concentrations of $1,007 \mathrm{Cu}, 160 \mathrm{Cr}, 470 \mathrm{Zn}, 12 \mathrm{Cd}$ and $281 \mathrm{~Pb}$ [in ppm dry weight]). The authors established that it is the most tolerant species to heavy metal pollution, followed by $H$. germanica and A. beccari in this order. In the Gota estuary $C$. excavatum and $H$. germanica were the pioneer species among others, after the recovery of this estuary (Cato et al., 1980). H. germanica dominates the foraminiferal assemblages in the contaminated sediments of Restronguet creek (UK) where the heavy metal content ranges from 382 to 1,270 ppm for $\mathrm{Cu} ; 742$ to 3,078 ppm for Zn; 0.5 to 4 ppm for Cd; and 616 to 2,387 ppm for As (Stubbles, 1993).

The observations made in Port Joinville harbor are in agreement with these results. Cribroelphidium excavatum and $H$. germanica have their highest relative abundance i) in the inner part of the marina where the sediment was deposited recently, circumstances favoring pioneer species; and ii) in the wet dock, highly polluted, which favors resistant species. However, C. excavatum and H. germanica are rare in station 13 that is the most contaminated by copper, lead, zinc and TBT. This may be due either to a stronger oceanic influence in this area, or to different speciations of the contaminants in the coarser sediments.

\section{5. The case of bolivinids}

Bolivina and Brizalina that are dominant in the fine sediments of the marina are known to survive in oxygen-deficient environments (Murray, 1991). They are often dominant in the oxygen-minimum zone or in upwelling zones (e.g., Phleger and Soutar, 1973; Poag, 1984; Mullins et al., 1985). Their flattened elongate morphology is considered to be an adaptation to the low-oxygen conditions (Bernhard, 1986). However, the oxygen content of the bottom water and the light brown color of the sediment do not indicate any oxygen depletion in the marina. The same kind of observations were made in La Turballe harbor, where the maximum abundance of living bolivinids was in the oxidized sediments of the marina (Debenay et al., 1997). One can only speculate whether the domestic activities on the pleasure boats produce some specific form of pollution (enrichment in phosphate, for example) that influences the benthic microfauna. The decrease in the assemblage density of the inner part of the marina (station 7) may be related to the high TBT content, but the contamination resulting from the careening of pleasure boats in summer may also include pollutants 
that are not detected by the analyses but have a negative effect on the microfauna, except the most resistant $C$. excavatum.

\section{6. The case of Elphidium pulvereum}

The correlation matrix shows that E. pulvereum, that is abundant only in the wet dock, is correlated with $\mathrm{Pb}, \mathrm{Zn}$ and to a smaller extent with $\mathrm{Cr}$ that are abundant in the wet dock. Thus, it should be inferred that E. pulvereum is resistant to these pollutants and that it could be used as a pollution indicator. However, the high level of water in the wet dock during the full tide cycle allows the growth of green algae that are less abundant elsewhere in the harbor and provide here a good support for the epiphytic E. pulvereum. Thus, despite the correlation indicated by the correlation matrix, it appears that there is probably no direct relation between the abundance of this species and the particular pollution of the wet dock.

It must be noted that the presence of epiphytic species in a sediment gives indirect information on the ecological condition of the environment, by indicating the presence of their algal support.

\section{7. The effect of the pollutants}

The pollutants that are grouped in the central area of the first plane of the factor analysis (1-2) have little influence on the distribution of foraminifers. The four elements that contribute to the distribution of the samples along axis $3(\mathrm{Cu}, \mathrm{Zn}$, As and $\mathrm{Pb})$ are among the most toxic in the classification of Wood (1974) and, except Pb, are present in high proportions in the sediment. The other elements (Ni, Hg, Cr, Cd) are either in low proportions in the sediment or have a low toxicity (Wood, 1974; Abel, 1989).

The correlation between heavy metals and the silt and clay fraction results from the fact that the distribution of heavy metals strongly depends on the adsorptive properties of clay minerals, and consequently follows sedimentological pattern. Therefore, geographic position is the main factor acting on foraminiferal distribution since it determines the characteristic of the sediment, itself affecting heavy metal concentration, and additionnally, is responsible for the gradient of marine influence. Owing to the correlation that occurs between heavy metals and the silt and clay fraction, it is difficult to determine whether sediment characteristics or pollution have the stronger influence on foraminiferal assemblages, except in the areas that experience the highest pollution. The impact of silt and clay fraction was evidenced for bolivinids.

\section{Conclusion}

This study shows that the main factor that determines the distribution of foraminiferal species in Port Joinville harbor is the geographical position, from the entrance towards the innermost areas. Correlations that occur between heavy metals and the silt and clay fraction makes it difficult to determine whether sediment characteristics or pollution have the stronger influence on foraminiferal assemblages in areas slightly affected by pollution. However, the nature of the sediment has a great influence on bolivinids, and strong pollution is indicated by the tolerant pioneer species $C$. excavatum and $H$. germanica. This general distribution concerns mainly the infaunal species. The growth of epiphytic species depends on the presence of algae and their distribution is influenced by local conditions such as the presence of the wet dock.

\section{Acknowledgments}


This work was made possible thanks to the financial support of the Conseil Général de Vendée. The chemical data were obtained from the "Étude des sédiments portuaires, Conseil Général de la Vendée/IFREMER, port de Port Joinville, 1998”. The study of algae was carried out with the participation of S. Lefrançois, K. Giraud and F. Le Barreau. Water circulation was studied with the participation of M. Mazeyrat and V. Lorenzi who also participated in the study of epiphytic species. Thanks are due to E. Bénéteau, S Sanchez and C. Hardouineau for their technical assistance. The SEM photographs were taken by $M$. Lesourd of the Service Commun de Microscopie Electronique (SCME) of Angers University. 


\section{Reference list}

Abel, P.D., 1989. Water Pollution Biology. Ellis Horwood, Chichester, UK, 231 pp.

Alve, E., 1991. Benthic foraminifera in sediment cores reflecting heavy metal pollution in Sorfjord, Western Norway. Journal of Foraminiferal Research 21, 1-19.

Alve, E., 1993. Benthic foraminiferal responses to estuarine pollution: a review. Geological society of America, Abstracts with programs 25, A. 137.

Alve, E., 1995. Benthic foraminifera response to estuarine pollution: a review. Journal of Foraminiferal Research 25, 190-203.

Alve, E., Nagy, J. 1986. Estuarine foraminiferal distribution in Sandebukta, a branch of the Oslo Fjord. Journal of Foraminiferal Research 16, 261-284.

Alve, E., Nagy, J. 1988. Pollution-induced changes in estuarine foraminiferal distribution in the Oslo Fjord. Abhandlungen der Geologischen Bundesanstalt 41, 11-12.

Alve, E., Olsgard, F. 1999. Benthic foraminiferal colonization in experiments with copper contaminated sediments. Journal of Foraminiferal Research 29, 186-195.

Alzieu, C., Michel, P., 1998. L’étain et les organoétains en milieu marin - Biogéochimie et écotoxicologie. Ifremer, Repères Océan 15, 104 pp.

Anonymous, 1996. Eaux marines - Pollutions par immersion, section II: dispositions prises sur le plan national, sous section II: normes de rejets. Lamy Environnement - 53062 - L’eau. Lamy SA.

Austen, M.C., McEvoy, A.J., Warwick, R.M., 1994. The specificity of meiobenthic community responses to different pollutants: result from microcosm experiments. Marine pollution bulletin 28, 557-563.

Bandy, O. L., Ingle, J. C, Resig, J. M., 1964. Foraminifera: Los Angeles County outfall area, California. Limnology and Oceanography 9, 124-137.

Bandy, O. L., Ingle, J. C., Resig, J. M., 1965. Modifications of foraminiferal distributions by the Orange County outfall, California. Marine Technology Society, Transactions, pp. 54-76.

Banerji, R. K., 1992. Heavy metals and benthic foraminiferal distribution along Bombay coast, India. Benthos'90, Sendai, Studies in Benthic Foraminifera, Tokai University Press, pp. 151-158

Bates, J. M., Spencer, R. S., 1979. Modification of foraminiferal trends by the Chesapeake-Elisabeth sewage outfall, Virginia. Journal of Foraminiferal Research 9, 125-140.

Bernhard, J. M. 1986. Characteristic assemblages and morphologies of benthic foraminifera from anoxic, organic-rich deposits: Jurassic through Holocene. Journal of Foraminiferal Research 16, 207-215.

Bhalla, S. N., Nigam, R., 1986. Recent foraminifera from polluted marine environment of Velsao Beach, South Goa, India. Revue de Paleobiologie 5, 43-46.

Blais-Stevens, A., Patterson, T., 1998. Environmental indicator potential of foraminifera from saanich inlet, Vancouver island, British Columbia, Canada. Journal of Foraminiferal Research 28, 201-219.

Boltovskoy, E., Lena, H., 1970. On the decomposition of the protoplasm and the sinking velocity of the planktonic foraminifers. Int. Rev. Ces. Hydrobiol. 55, 797-804.

Cann, J. H., Deckker, P. de, 1981. Fossil Quaternary and living foraminifera from athalassic (non-marine) Saline lakes, Southern Australia. J. Paleont. 55, 660-670.

Casamajor, M.N. de, Debenay, J.-P., 1995. Les Foraminifères, bio-indicateurs des environnements paraliques: reaction à divers types de pollution dans l'estuaire de 
l'Adour: ANPP-Colloque International "Marqueurs Biologiques de Pollution”, Abstracts Volume, Chinon-France, pp. 371-377.

Cato, I., Olsson, L., Rosenberg, R., 1980. Recovery and decontamintation of estuaries. In: Ollauson, E., Cato, I. (Eds.), Chemistry and Biogeochemistry of Estuaries. John Wiley and Sons Ltd., Chichester, pp. 403-440.

Cearreta, A., Irabien, M.J., Leorri A., Yusta I., Croudace, I.W., Cundy, A.B., 2000. Recent Anthropic Impacts on the Bilbao Estuary, Northern Spain: Geochemical and Microfaunal Evidence. Estuarine, Coastal and Shelf Science 50, pp. 571-592.

Clark, D. F., 1971. Effects of agriculture outfall on benthonic foraminifera in Clam Bay, Nova Scotia. Maritime Sediments 4, 76-84.

Cossa, D., Lassus, P., 1989. Le Cadmium en milieu marin - Biogéochimie et Ecotoxycologie. Rapports scientifiques et techniques de l'Ifremer 16, $111 \mathrm{p}$.

Coste, M., Lenoir A, 1996. Development of a practical diatom index of overall water quality applicable to the French National Water Board Network. Proceedings of an International Symposium held at the Volksbildungsheim Grilhof, Vill near Innsbruck, AUT, 17-19 septembre 1995. In : Whitton, B.A., Rott, E. (Eds), Use of algae for monitoring rivers II, Universität Innsbruck, AUT., pp. 29-43

Cronan, D.S., 1972. The mid Atlantic Ridge near $45^{\circ} \mathrm{N}$ : $\mathrm{Al}$, As, $\mathrm{Hg}$ and $\mathrm{Mn}$ in ferruginous sediments from the median valley. Canadian Journal of Earth Sciences 9, 319-323.

Culver, S.J., Buzas, M. A., 1981. Recent benthic foraminiferal provinces on the Altantic continental margin of North America. Journal of Foraminiferal Research 11, 217240.

Debenay, J-P., 1978. Distribution des Foraminifères vivants et des tests vides dans la baie de Bourgneuf. PhD thesis, Université de Paris VI., 196 pp., 18 pl.

Debenay, J.-P., Andre, O., Bezie, S., Rambaud, S., 1997. Foraminifers used as bioindicators in La Turballe harbor (Loire Atlantique, France). Coastal zone monitoring and medium to long term forecasting, French-Japanese International Symposium, Paris, October 6-8, 1997, Abstracts Volume.

Debenay, J.-P., Guillou, J.J., Redois, F., Geslin, E., 2000. Distribution trends of foraminiferal assemblages in paralic environments: a base for using foraminifera as early warning indicators of anthropic stress. In: R. Martin (Ed.), Environmental Micropaleontology, Plenum Publishing Corporation, pp. 39-67.

Dupeuble, P.A., 1963. Répartition des principales familles de foraminifères dans trois faciès de la région de Roscoff (Finistère). Revue de Micropaléontologie 5, 277279.

Dupeuble, P.A., Mathieu, R., Moméni, I., Poignan, A., Rosset-Moulinier, M., Rouvillois, A., Ubaldo, M., 1971. Recherche sur les foraminifères actuels des côtes françaises de la Manche et de la Mer du Nord. Revue de Micropaléontologie 14, 83-95.

Goubert, E., 1997. Les Elphidium excavatum (Terquem), foraminifères benthiques, vivant en Baie de Vilaine (Bretagne, France) d'octobre 1992 à septembre 1996: morphologie, dynamique de population et relation avec l'environnement. Thèse de doctorat, Université de Nantes, 186 pp., 30 pl.

Grant, A., Middleton, R., 1990. An assessment of Metal Contamination of sediments in the Humber Estuary, U.K. Estuarine, Coastal and Shelf Science 31, pp. 71-85.

Groot, A.J. de, Allersma, F., 1976. Field observations on the transport of heavy metals in sediments. In: Krenkel, P. A. (Ed.), Heavy metals in the aquatic environment. Pergamont Press, London, pp. 85-95. 
Groot, A.J. de, Salomons, W., Allersma, E., 1976. Processes affecting heavy metals in estuarine sediments. In: Burton, J.D., Liss, P.S. (Eds.), Estuarine chemistry. Academic Press London, pp. 131-157.

Kennish, M.J., 1992. Ecology of estuaries: Anthropogenic effects. CRC Press, Inc, Boca Raton, Florida, 494 pp.

Langston, W.J., 1984. Availability of arsenic to estuarine and marine organisms: A field and laboratory evaluation. Marine Biology 80, 143-154.

Le Campion, J., 1968. Foraminfères des principaux biotopes du Bassin d'Arcachon et du proche océan (inventaire faunistique). Bulletin du centre d'études et de recherche scientifique, Biarritz 7, 207-391.

Le Campion, J., 1970. Contribution à l'étude des foraminifères du Bassin d'Arcachon et du proche ocean. Bulletin de l'Institut Géologique du Bassin d'Aquitaine 8, 3-98.

Linke, P., Lutze, G. F., 1993. Microhabitat preferences of benthic foraminifera a static concept or a dynamic adaptation to optimize food acquisition? Marine Micropaleontology 20, 215-234.

Michel, P., Averty, B., 1995. La contamination de la rade de Brest par le tributylétain. Contrat de Baie Rade de Brest. 3èmes Rencontres Scientifiques Internationales, 15-17 mars 1995. Actes, 2, pp. 87-96.

Mullins, H.T., Thompson, J.B., McDougall, K., Vercoutere, T.L., 1985. Oxygen minimum zone edge effects: evidence from the central California coastal upwelling system. Geology 13, 491-494.

Murray, J. W., 1968. Living foraminifers of lagoons and estuaries. Micropaleontology $14,435-455$.

Murray, J. W., 1991. Ecology and paleoecology of benthic foraminifera. Longman, Harlow, 397 pp.

Naidu, T. Y., Rao, D. C., Rao, M. S., 1985. Foraminifera as pollution indicators in the Vissakhapatnam harbor Complex, east coast of India. Bulletin of Geological. Mining and Metallurgical Society of India 52, 88-96.

Olsson, J., Rosenberg, R., Ølundh, E., 1973. Benthic fauna and zooplankton in some polluted Swedish estuaries. Ambio 2, 158-163.

Patterson, R.T., 1990. Intertidal benthic foraminiferal biofacies on the Fraser River Delta, British Columbia: modern distribution and paleoecological importance. Micropaleontology 36, 229-244.

Phleger, F. B., Soutar, A., 1973. Production of benthic Foraminifera in three East Pacific oxygen minima. Micropaleontology 19, 110-115

Poag, C. W., 1984. Distribution and ecology of deep-water benthic foraminifera in the Gulf of Mexico. Palaeogeogeography, Palaeoclimatology, Palaeoecology 48, 2537.

Redois, F., Debenay, J-P., 1996. Influence du confinement sur la répartition des foraminifères benthiques. Exemple de l'estran d'une ria mésotidale de Bretagne méridionale. Revue de Paléobiologie, Genève 15, 243-260.

Rosset-Moulinier, M., 1972. Étude des foraminifères des côtes nord et ouest de Bretagne. Travaux du laboratoire de géologie, Ecole Normale Superieure, Paris. $\mathrm{n}^{\circ}$ 6, $225 \mathrm{pp} ., 30 \mathrm{pl}$.

Rouvillois, A., 1967. Observations morphologiques, sédimentologiques et écologiques sur le plage de Ville Ger, dans l'estuaire de la Rance. Cahiers d'Océanographie 19, 375-389.

Rouvillois, A., 1972. biocoenose des foraminifères en relation avec les conditions physico-chimiques du milieu dans les bassins et l'avant-port de Saint-Malo (Ile et Vilaine). Cahiers de micropaléontologie ser. 3, 1, 1-10, 2pls. 
Schafer, C.T., 1973. Distribution of foraminifera near pollution sources in Chaleur Bay. Water. Air and Soil Pollution 2, 219-233.

Schafer, C.T., Cole, F.E., 1974. Distribution of benthic foraminifera: Their use in delimiting local near shore environments. Offshore geology of Canada, Eastern Canada. Geological Survey of Canada, Paper 74-30, v. 1, pp. 103-108.

Schafer, C.T., Winters, G.V., Scott, D.B., Pocklington, P., Cole, F. E., Honig, C., 1995. Survey of living foraminifera and polychaete populations at some Canadian aquaculture sites: Potential for impact mapping and monitoring. Journal of Foraminiferal Research 25, 236-259.

Setty, M.G.A.P., 1982. Pollution effects monitoring with foraminifera as indices in the Thana Greek, Bombay Area: International. Journal of Environmental Studies 18, 205-209.

Sharifi, A.R., Croudace, I.W., Austin, R.L., 1991. Benthic foraminiferids as pollution indicators in Southampton Water, Southern England. Journal of Micropaleontology 10, 109-113.

Stang, P.M., Seligan, P.F., 1986. Distribution and fate of butyltin compounds in the sediment of San Diego Bay. Ocean's 86, Washington, 23-25 September 1986. Conference proceedings, Organotin symposium, v. 4, pp. 1256-1261.

Strubbles, S., 1993. Recent benthic foraminiferida as indications of pollution in Restronguet creek, Cornwall. Note of poster display at the annual conference of the Ussher Society. Proceedings of the Ussher Society. January 1993, pp. 200204.

Vénec-Peyré, M.T., 1981. Les Foraminiferes et la pollution: etude de la microfaune de la Cale du Dourduff (Embochure de la Riviere de Morlaix). Cahiers de Biologie Marine 22, 25-33.

Vénec-Peyré, M.T., 1982. Étude de l’influence du milieu sur la distribution, la morphologie et la composition des tests de foraminifères benthiques. Implications paléoécologiques. Thèse de doctorat es Sciences Naturelles, université de Paris 6, 217 pp.

Watkins, J. G., 1961. Foraminiferal ecology around the Orange County, California, ocean sewer outfall. Micropaleontology 7, 199-206.

Wood, J.M. 1974. Biological cycles for toxic elements in the environment. Science 183, 1049-1052.

Yanko, V., Ahmad, M., Kaminski, M., 1998. Morphological deformities of benthic foraminiferal tests in response to pollution by heavy metals: implications for pollution monitoring. Journal of Foraminiferal Research 28, 177-200.

Yanko, V., Arnold, A., Parker, W., 1999. Effect of marine pollution on benthic foraminifera. In: Sen Gupta, B.K., (Ed.), Modern Foraminifera. Kluwer acad. Pub.: 217-235. 


\section{TABLES}

Table 1

Contaminant concentration in the sediments

\begin{tabular}{|c|c|c|c|c|c|c|c|c|c|c|c|c|c|c|c|c|c|}
\hline No sample & 1 & 2 & 3 & 4 & 5 & 6 & 7 & 8 & 9 & 10 & 11 & 12 & 13 & 14 & 15 & 17 & 18 \\
\hline Dry weight (\% of total weight) & 26.4 & 66.1 & 50.8 & 40.3 & 37.9 & 39 & 42.9 & 45.2 & 35.5 & 37 & 38.8 & 37.2 & 37.9 & 46.3 & 40.1 & 33.2 & 37 \\
\hline T.O.C. (\% dry weight) & 3.4 & 1.3 & 2.8 & 3.2 & 3.7 & 1.7 & 3.3 & 6.3 & 4.3 & 11 & 2 & 12 & 12 & 11 & 12 & 11 & 12 \\
\hline $\mathrm{Al}$ (\% dry weight) & 3.6 & 4.1 & 4.8 & 5.1 & 6.2 & 5.6 & 4.3 & 6 & 6.4 & 6.4 & 5.7 & 5.8 & 6.2 & 5.4 & 6.3 & 5.6 & 4.6 \\
\hline As ( $\mathrm{mg} / \mathrm{kg}$ dry sediment) & 9.3 & 8.8 & 13 & 19 & 35 & 120 & 100 & 23 & 22 & 20 & 19 & 20 & 21 & 21 & 21 & 27 & 31 \\
\hline $\mathrm{Cd}$ (mg/kg dry sediment) & 0.26 & 0.22 & 0.46 & 0.56 & 0.62 & 0.78 & 0.5 & 1.4 & 1 & 1 & 0.52 & 0.5 & 0.66 & 0.6 & 0.68 & 1 & 1.1 \\
\hline $\mathrm{Cr}$ total (mg/kg dry sediment) & 31 & 13 & 38 & 32 & 69 & 63 & 59 & 31 & 52 & 42 & 51 & 53 & 63 & 59 & 54 & 62 & 79 \\
\hline $\mathrm{Cu}$ (mg/kg dry sediment) & 11 & 9 & 90 & 58 & 63 & 71 & 63 & 69 & 110 & 110 & 67 & 130 & 1100 & 60 & 68 & 340 & 440 \\
\hline $\mathrm{Hg}$ (mg/kg dry sediment) & 0.21 & 0.03 & 0.08 & 0.09 & 0.08 & 0.03 & 0.07 & 0.06 & 0.35 & 0.35 & 0.03 & 0.06 & 0.09 & 0.05 & 0.06 & 0.08 & 0.03 \\
\hline $\mathrm{Ni}$ (mg/kg dry sediment) & 11 & 9 & 17 & 21 & 27 & 31 & 29 & 22 & 24 & 25 & 22 & 23 & 35 & 25 & 25 & 27 & 33 \\
\hline $\mathrm{Pb}$ (mg/kg dry sediment) & 20 & 14 & 27 & 36 & 40 & 39 & 36 & 44 & 54 & 63 & 42 & 49 & 640 & 44 & 48 & 97 & 750 \\
\hline Zn (mg/kg dry sediment) & 69 & 70 & 130 & 190 & 180 & 190 & 180 & 190 & 370 & 340 & 180 & 240 & 1000 & 210 & 250 & 690 & 790 \\
\hline HPA (mg/kg dry sediment) & 0.54 & 0.14 & 2.2 & 1.3 & 0.99 & 0.58 & 0.97 & & 1.8 & 1.3 & & 2.4 & 5.5 & & 2 & 3.2 & 3.2 \\
\hline PCB (micro-g/kg dry sediment) & 27 & 3 & 64 & 9 & 20 & 9 & 13 & & 140 & 27 & & 22 & 29 & & 21 & 39 & 200 \\
\hline TBT (micro-g/kg dry sediment) & & 2000 & & 880 & & 6280 & & 4700 & & & 1490 & 54700 & & 2870 & & 23500 & \\
\hline TPhT (micro-g/kg dry sediment) & & 5 & & 5 & & 18 & & 11 & & & 6 & 14400 & & 21 & & 437 & \\
\hline fecal coliforms $n / g$ & 9.2 & 3 & 3.6 & 3 & 43 & 3.6 & 150 & & 43 & 20 & & 9.2 & 9.2 & & 9.2 & 23 & \\
\hline fecal streptococci n/g & 1100 & 2400 & 260 & 1100 & 150 & 2400 & 2400 & & 28000 & 750000 & & 1500 & 750 & & 46000 & 7500 & \\
\hline
\end{tabular}

Table 1. Contaminant concentration in the sediments.

\begin{tabular}{|c|c|c|c|c|c|c|c|c|c|c|c|c|}
\hline & T.O.C. & $\mathrm{Al}$ & As & $\mathrm{Cd}$ & $\mathrm{Cr}$ & $\mathrm{Cu}$ & $\mathrm{Hg}$ & $\mathrm{Ni}$ & $\mathrm{Pb}$ & $\mathrm{Zn}$ & $<63 \mu \mathrm{m}$ & Median \\
\hline No specimens $/ 50 \mathrm{~cm}^{3}$ & -0.287 & -0.063 & -0.538 & -0.171 & -0.549 & -0.162 & -0.112 & -0.568 & -0.223 & -0.337 & -0.579 & 0.477 \\
\hline No species & 0.308 & 0.538 & -0.131 & 0.298 & -0.113 & -0.132 & 0.121 & 0.111 & -0.310 & -0.077 & 0.088 & -0.172 \\
\hline Angulogerina angulosa & 0.068 & -0.211 & -0.357 & -0.234 & -0.384 & -0.049 & 0.069 & -0.463 & -0.194 & -0.120 & -0.158 & 0.081 \\
\hline Asterigerinata mamilla & -0.114 & -0.201 & -0.219 & -0.272 & -0.294 & 0.011 & 0.228 & -0.246 & -0.139 & -0.015 & -0.168 & 0.119 \\
\hline Bolivina difformis & 0.084 & 0.096 & -0.250 & -0.297 & 0.076 & 0.345 & -0.285 & 0.032 & 0.289 & 0.234 & -0.045 & 0.091 \\
\hline Bolivina pseudoplicata & 0.430 & 0.738 & 0.088 & 0.373 & 0.267 & 0.500 & 0.136 & 0.489 & 0.176 & 0.458 & 0.381 & -0.358 \\
\hline Bolivina sp.1 & 0.323 & 0.589 & 0.358 & 0.437 & 0.320 & 0.289 & 0.269 & 0.525 & 0.121 & 0.276 & 0.435 & -0.422 \\
\hline Brizalina variabilis & 0.170 & 0.413 & 0.044 & 0.729 & 0.019 & -0.113 & 0.384 & 0.219 & 0.043 & 0.065 & 0.148 & -0.226 \\
\hline Bulimina elegans & 0.302 & 0.283 & -0.143 & 0.383 & 0.329 & 0.274 & 0.363 & 0.312 & 0.256 & 0.529 & 0.167 & -0.089 \\
\hline Cassidulina crassa & 0.333 & 0.518 & -0.238 & 0.055 & 0.118 & -0.164 & 0.509 & 0.017 & -0.292 & -0.104 & 0.332 & -0.425 \\
\hline Cribroelphidium excavatum & -0.139 & -0.373 & 0.783 & -0.054 & 0.424 & 0.004 & -0.097 & 0.389 & 0.203 & 0.052 & 0.195 & -0.077 \\
\hline Cribroelphidium magellanicum & -0.041 & -0.094 & 0.633 & 0.016 & 0.342 & -0.098 & -0.099 & 0.427 & -0.039 & -0.080 & 0.253 & -0.230 \\
\hline Cribrononion gerthi & 0.426 & 0.405 & -0.216 & 0.152 & 0.242 & 0.393 & -0.222 & 0.234 & 0.106 & 0.361 & 0.372 & -0.340 \\
\hline Cribrostomoides jeffreysii & -0.011 & 0.358 & 0.276 & 0.065 & 0.120 & 0.033 & 0.457 & 0.221 & -0.084 & 0.021 & 0.235 & -0.213 \\
\hline Elphidium pulvereum & 0.408 & -0.161 & 0.049 & 0.379 & 0.581 & 0.393 & -0.173 & 0.459 & 0.691 & 0.653 & 0.273 & -0.153 \\
\hline Fissurina lucida & 0.088 & 0.463 & 0.265 & 0.410 & 0.109 & -0.223 & 0.629 & 0.259 & -0.243 & -0.052 & 0.265 & -0.278 \\
\hline Gavelinopsis praegeri & -0.335 & 0.067 & -0.463 & -0.244 & -0.319 & -0.160 & 0.327 & -0.397 & -0.298 & -0.252 & -0.051 & -0.076 \\
\hline Haynesina germanica & 0.228 & -0.401 & 0.331 & 0.205 & 0.487 & 0.174 & -0.251 & 0.408 & 0.544 & 0.377 & 0.211 & -0.106 \\
\hline Lepidodeuterammina ochracea & 0.220 & 0.355 & 0.199 & 0.665 & -0.088 & 0.158 & 0.183 & 0.295 & 0.102 & 0.161 & 0.229 & -0.280 \\
\hline Lobatula lobatula & -0.305 & -0.265 & -0.506 & -0.438 & -0.531 & -0.141 & -0.001 & -0.653 & -0.210 & -0.353 & -0.546 & 0.416 \\
\hline Neoconorbina nitida & 0.404 & 0.398 & -0.146 & 0.093 & 0.073 & 0.023 & 0.024 & 0.138 & -0.142 & 0.048 & 0.229 & -0.284 \\
\hline Palliolatella orbignyana & -0.195 & 0.202 & -0.217 & -0.079 & -0.078 & -0.245 & -0.077 & -0.077 & -0.224 & -0.291 & 0.032 & -0.167 \\
\hline Planorbulina mediterranensis & -0.490 & -0.592 & -0.264 & -0.614 & -0.656 & -0.336 & -0.194 & -0.752 & -0.278 & -0.486 & -0.892 & 0.895 \\
\hline Rosalina globularis & 0.352 & 0.349 & -0.223 & -0.070 & 0.282 & 0.373 & -0.358 & 0.185 & 0.158 & 0.275 & 0.174 & -0.136 \\
\hline Textularia truncata & -0.135 & 0.186 & -0.476 & -0.015 & -0.385 & -0.392 & 0.115 & -0.418 & -0.503 & -0.433 & -0.030 & -0.103 \\
\hline T.O.C. & 1.000 & & & & & & & & & & & \\
\hline $\mathrm{Al}$ & 0.406 & 1.000 & & & & & & & & & & \\
\hline As & -0.269 & -0.055 & 1.000 & & & & & & & & & \\
\hline $\mathrm{Cd}$ & 0.398 & 0.543 & 0.081 & 1.000 & & & & & & & & \\
\hline $\mathrm{Cr}$ & 0.453 & 0.345 & 0.413 & 0.323 & 1.000 & & & & & & & \\
\hline $\mathrm{Cu}$ & 0.513 & 0.227 & -0.085 & 0.196 & 0.426 & 1.000 & & & & & & \\
\hline $\mathrm{Hg}$ & 0.044 & 0.253 & -0.222 & 0.213 & -0.168 & -0.070 & 1.000 & & & & & \\
\hline $\mathrm{Ni}$ & 0.493 & 0.506 & 0.491 & 0.516 & 0.873 & 0.589 & -0.114 & 1.000 & & & & \\
\hline $\mathrm{Pb}$ & 0.503 & 0.011 & -0.058 & 0.291 & 0.519 & 0.830 & -0.148 & 0.586 & 1.000 & & & \\
\hline $\mathrm{Zn}$ & 0.647 & 0.286 & -0.072 & 0.438 & 0.575 & 0.912 & 0.020 & 0.687 & 0.858 & 1.000 & & \\
\hline silt and clay $(<63 \mu \mathrm{m})$ & 0.332 & 0.425 & 0.408 & 0.456 & 0.768 & 0.210 & 0.007 & 0.722 & 0.196 & 0.372 & 1.000 & \\
\hline median & -0.388 & -0.450 & -0.257 & -0.438 & -0.675 & -0.195 & -0.128 & -0.648 & -0.176 & -0.319 & -0.956 & 1.000 \\
\hline
\end{tabular}

Table 2. Correlation between selected species of foraminifers and pollutant concentration of the sediment. 


\begin{tabular}{|c|c|c|c|c|c|c|c|c|}
\hline & Mini & Maxi & Average & Géode & $\%$ of samples over Géode & $\begin{array}{l}\text { Humber } \\
\text { pre-indust. }\end{array}$ & $\begin{array}{l}\text { Humber } \\
\text { recent }\end{array}$ & $\begin{array}{l}\text { Bilbao } \\
\text { estuary }\end{array}$ \\
\hline As (mg/kg dry sediment) & 8.8 & 120 & 31.18 & 25 & 29 & 22 & 150 & 99 \\
\hline $\mathrm{Cd}$ (mg/kg dry sediment) & 0.22 & 1.4 & 0.7 & 1.2 & 6 & & & \\
\hline $\mathrm{Cr}$ total (mg/kg dry sediment) & 13 & 79 & 50.06 & 90 & 0 & 99 & 163 & 310 \\
\hline $\mathrm{Cu}$ (mg/kg dry sediment) & 9 & 1100 & 168.2 & 45 & 88 & 17 & 118 & 263 \\
\hline $\mathrm{Hg}$ (mg/kg dry sediment) & 0.03 & 0.35 & 0.1 & 0.4 & 0 & & & \\
\hline Ni (mg/kg dry sediment) & 9 & 35 & 23.88 & 37 & 0 & 38 & 59 & 49 \\
\hline $\mathrm{Pb}$ (mg/kg dry sediment) & 14 & 750 & 120.18 & 100 & 12 & 22 & 158 & 314 \\
\hline $\mathrm{Zn}$ (mg/kg dry sediment) & 69 & 1000 & 309.94 & 276 & 35 & 84 & 314 & 1092 \\
\hline PCB (micro-g/kg dry sediment) & 3 & 200 & 44.5 & 500 & 0 & & & \\
\hline
\end{tabular}

Table 3. Comparison of the contaminant concentrations in the sediments of Port Joinville harbor (minimum, maximum and average) with the GEODE medians (medians of heavy metal and PCB concentrations in the sediments of the major French harbors), with pre-industrial and recent sediments of the Humber estuary (Grant and Middleton, 1990) and with the polluted Bilbao estuary (Cearreta et al, 2000). 


\section{FIGURES}

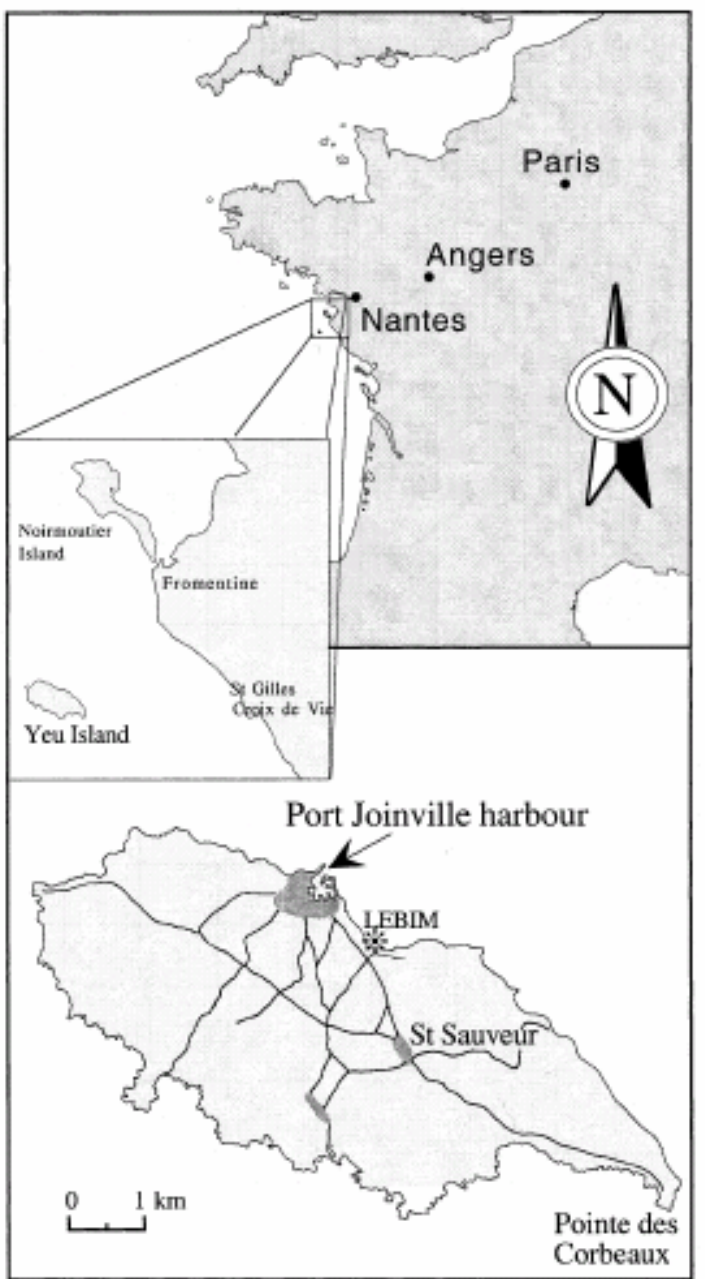

Figure 1. Location map.

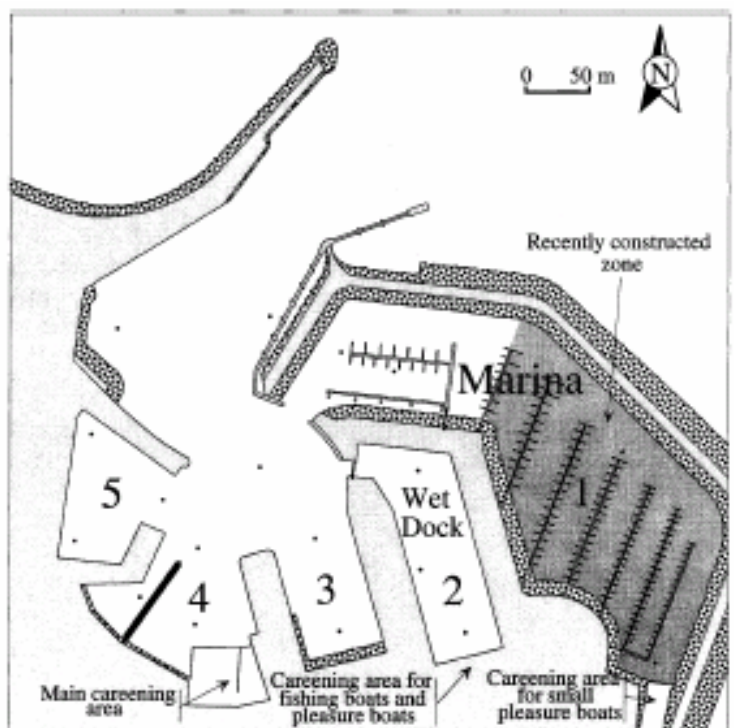

Figure 2. Map of Port Joinville harbor. 


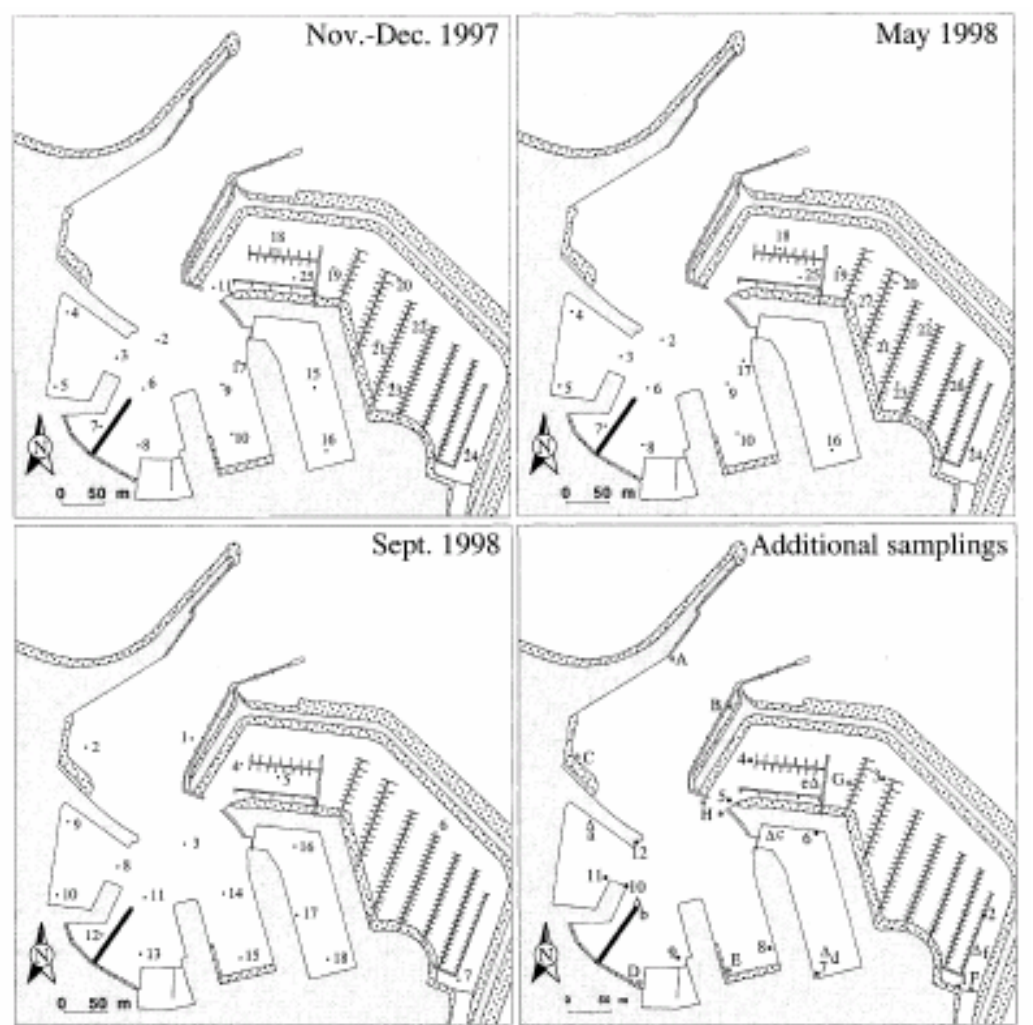

Figure 3. Location of the sampling stations. Additional samplings are: A to $G$ sea weeds, 1 to 12 epiphytic foraminifers, a to f stations where 12 hours monitoring were carried out. 

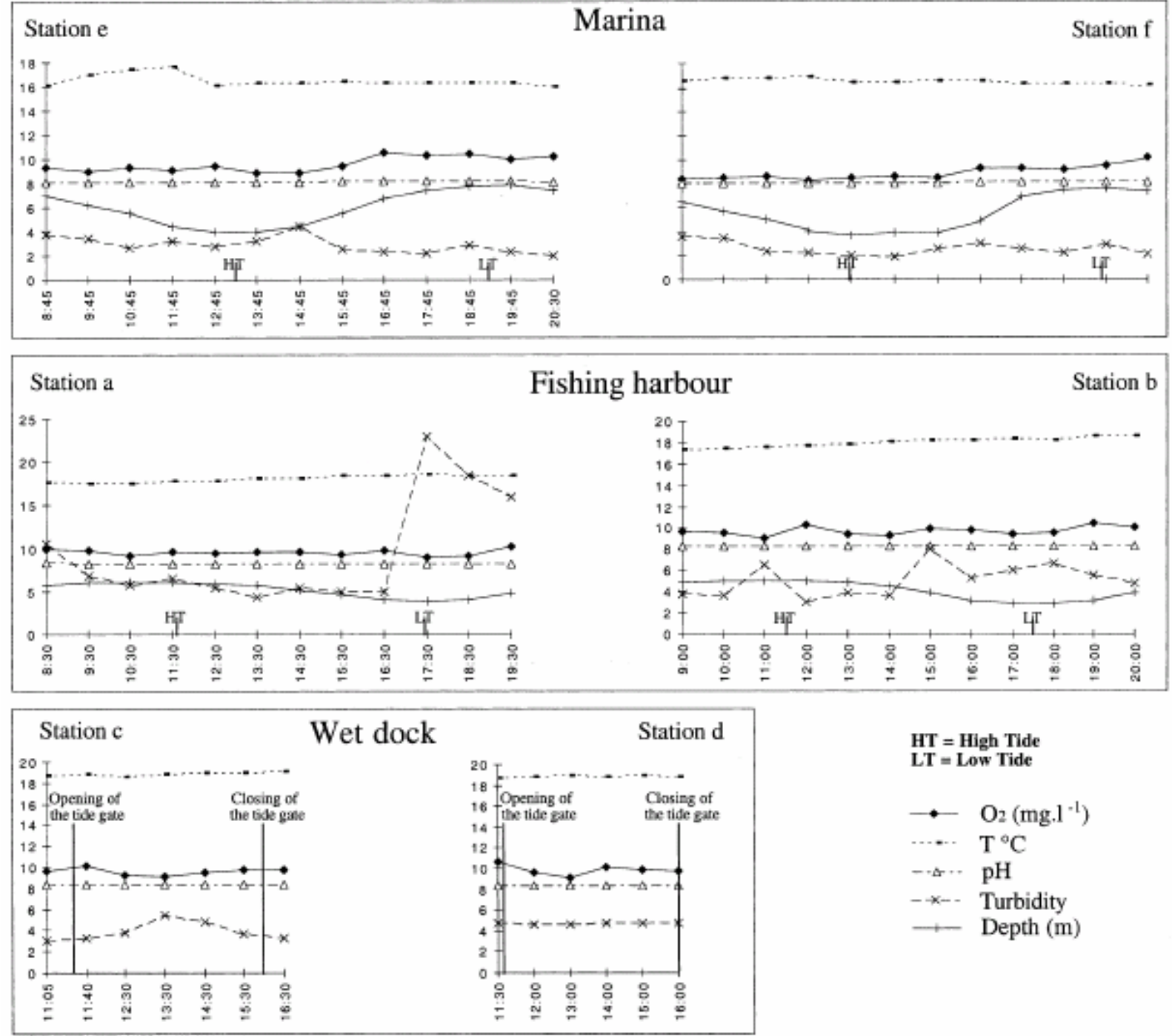

HT $=$ High Tide

LT $=$ Low Tide

$\because \mathrm{O}_{2}\left(\mathrm{mg}^{-1} \mathrm{l}^{-\mathrm{l}}\right)$

..... $\mathrm{T}^{\circ} \mathrm{C}$

$\because \backsim \cdots p H$

$-x--$ Turbidity

$\longrightarrow$ Depth (m)

Figure 4. Variation of the hydrological parameters of the bottom water during a tide cycle. 

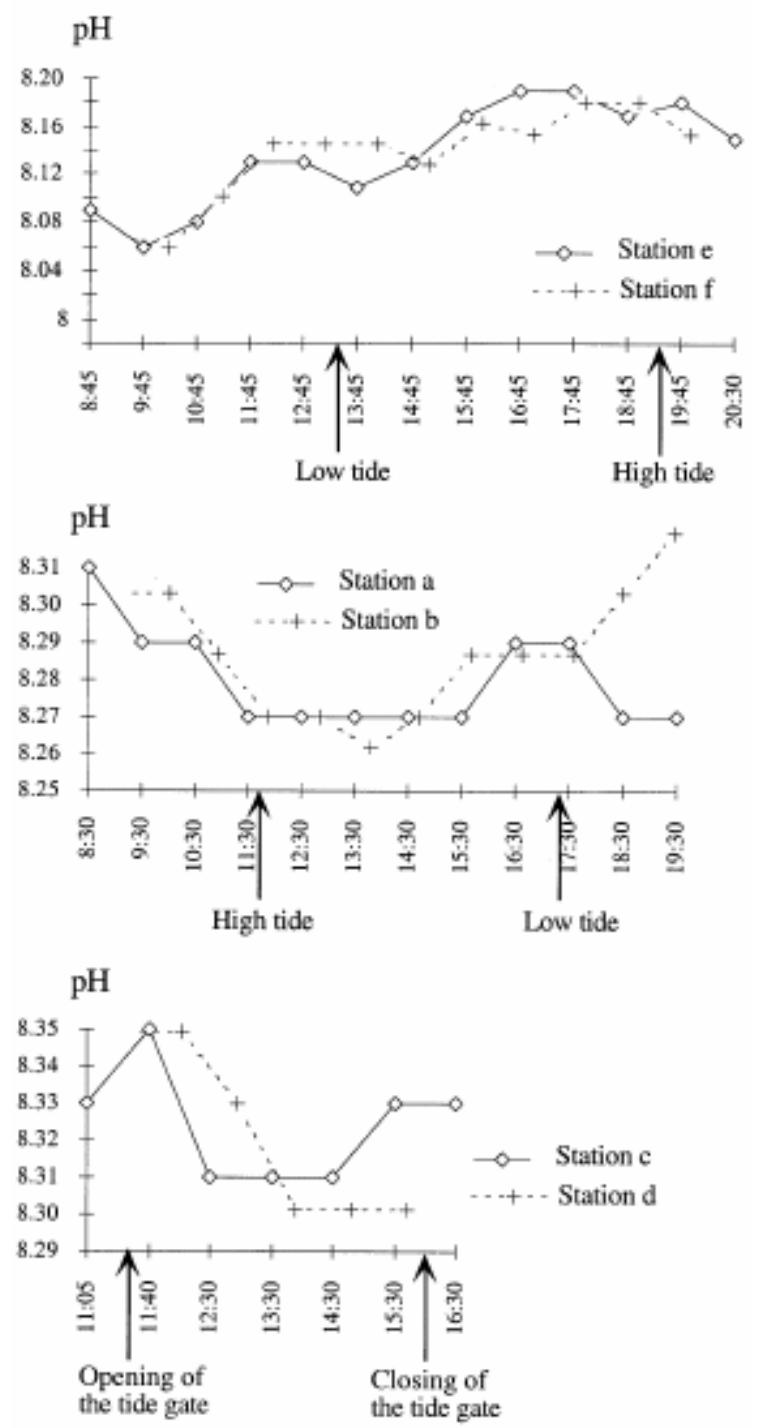

Figure 5. Changes in $\mathrm{pH}$ values of the bottom water during a tide cycle.

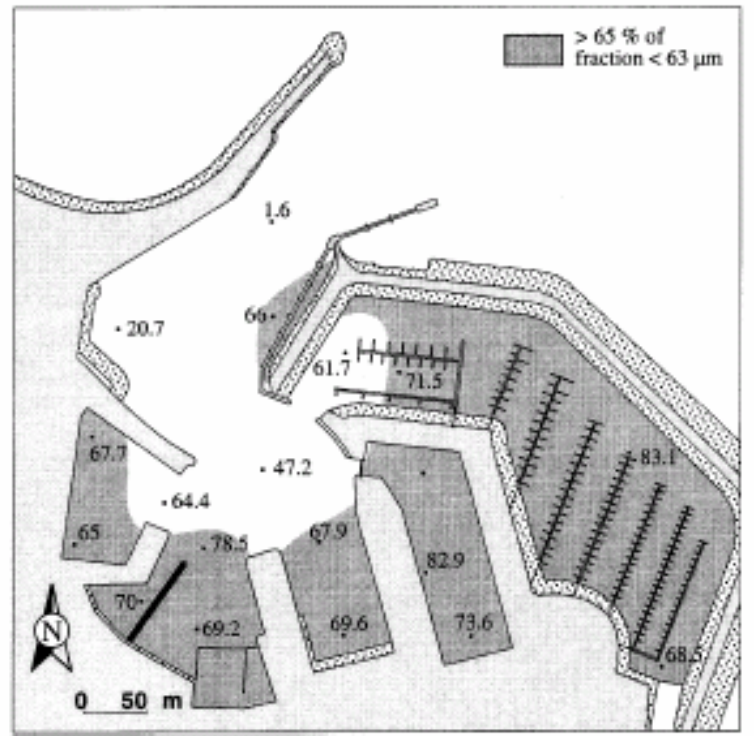

Figure 6. Silt and clay content of the sediment $(<63 \mu \mathrm{m})$. 

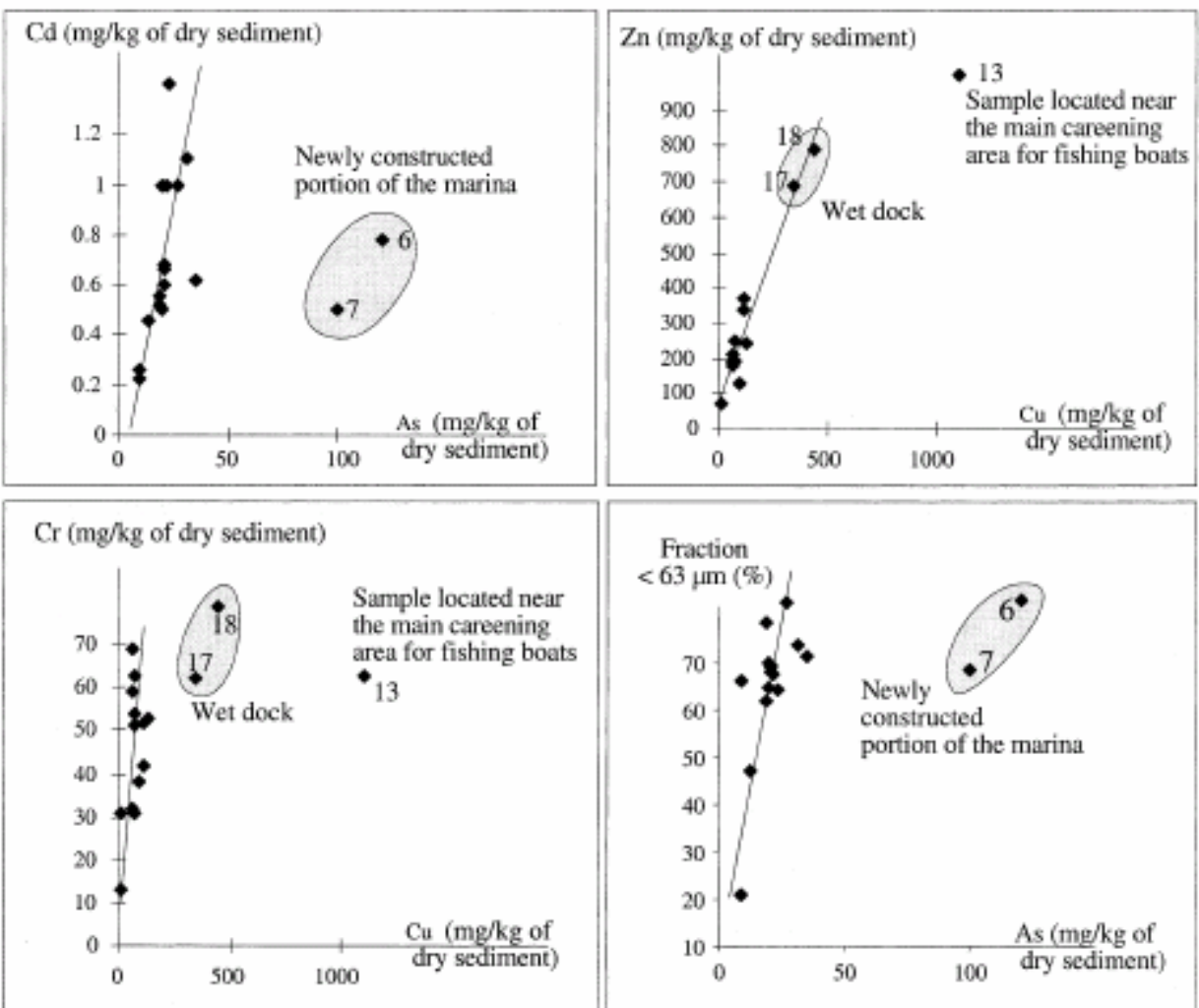

Figure 7. Dispersion diagrams of $\mathrm{Cd}$ against $\mathrm{As}$, $\mathrm{Zn}$ and $\mathrm{Cr}$ against $\mathrm{Cu}$, and As against silt and clay content.

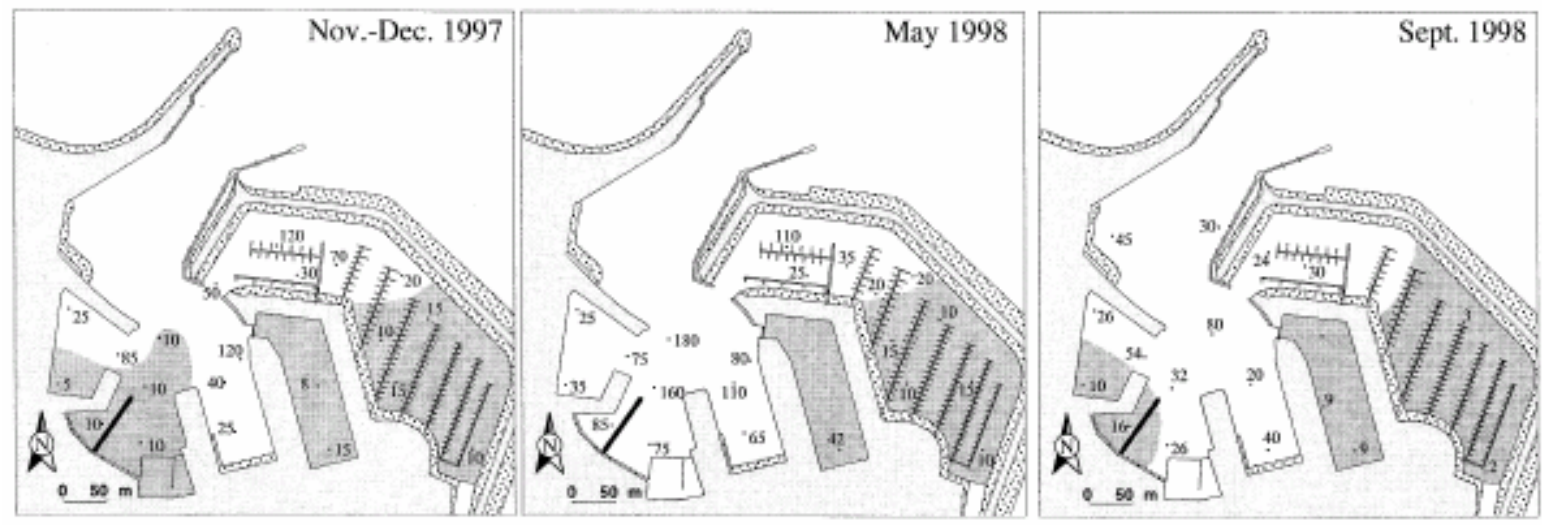

Figure 8. Number of individuals (x 10-3) in $50 \mathrm{~cm}^{3}$ of sediment during the three sampling periods. 


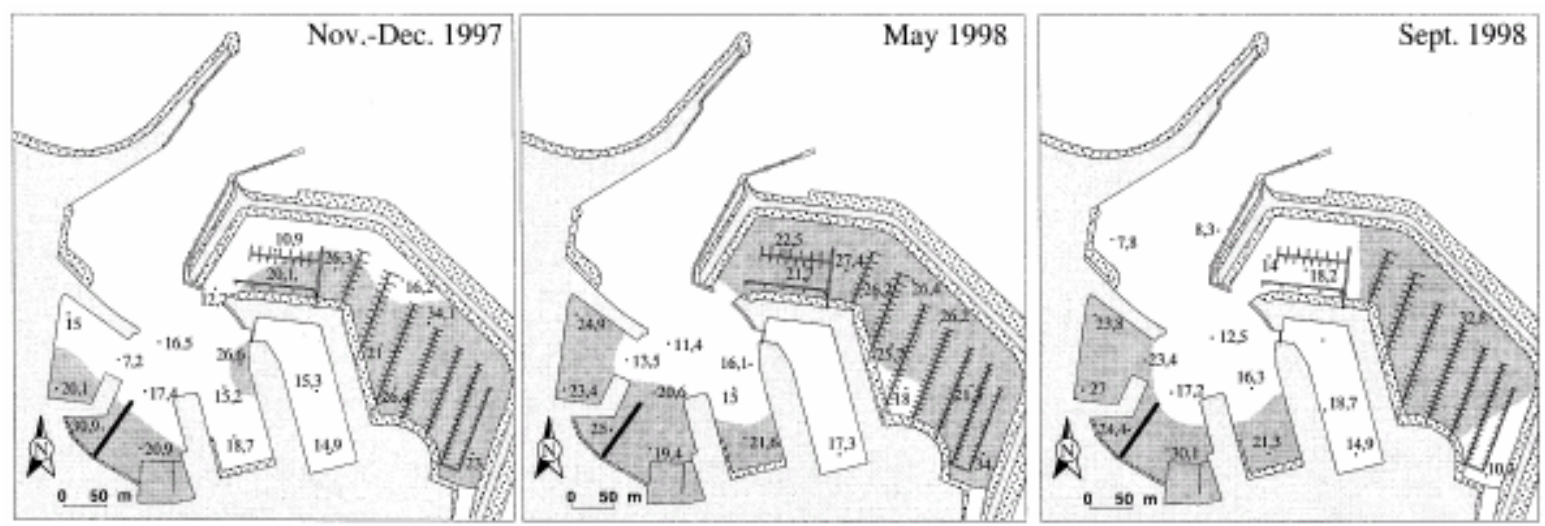

Figure 9. Relative abundance of the bolivinids during the three sampling periods.

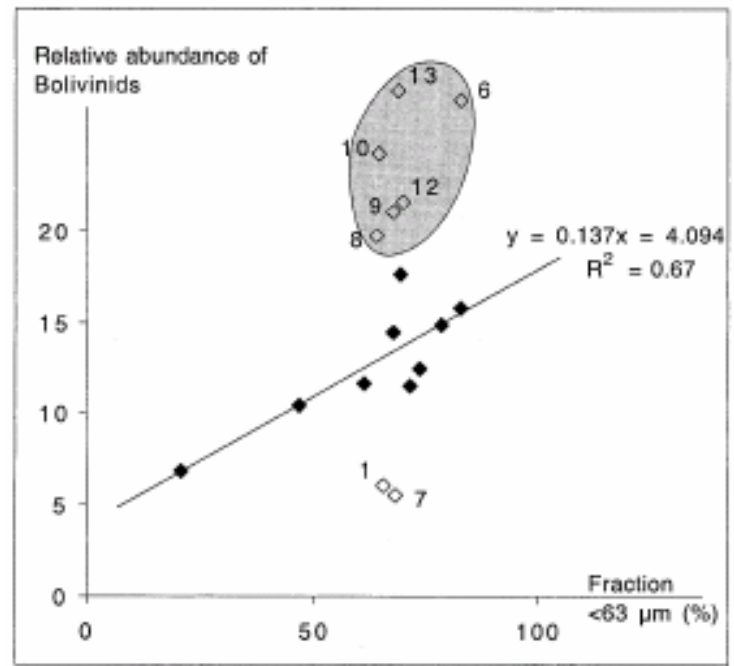

Figure 10. Relative abundance of the bolivinids against silt and clay content of the sediment. 

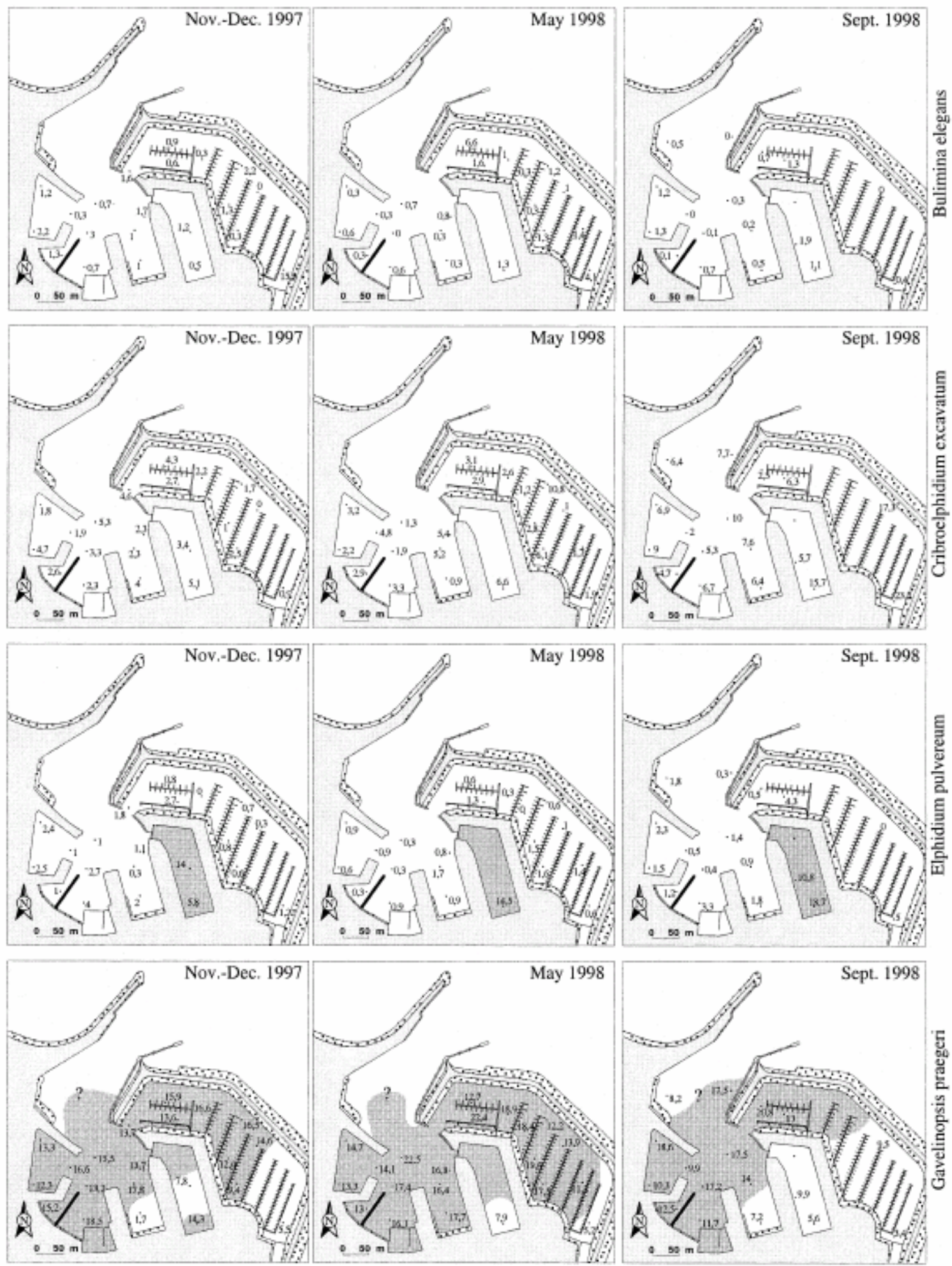

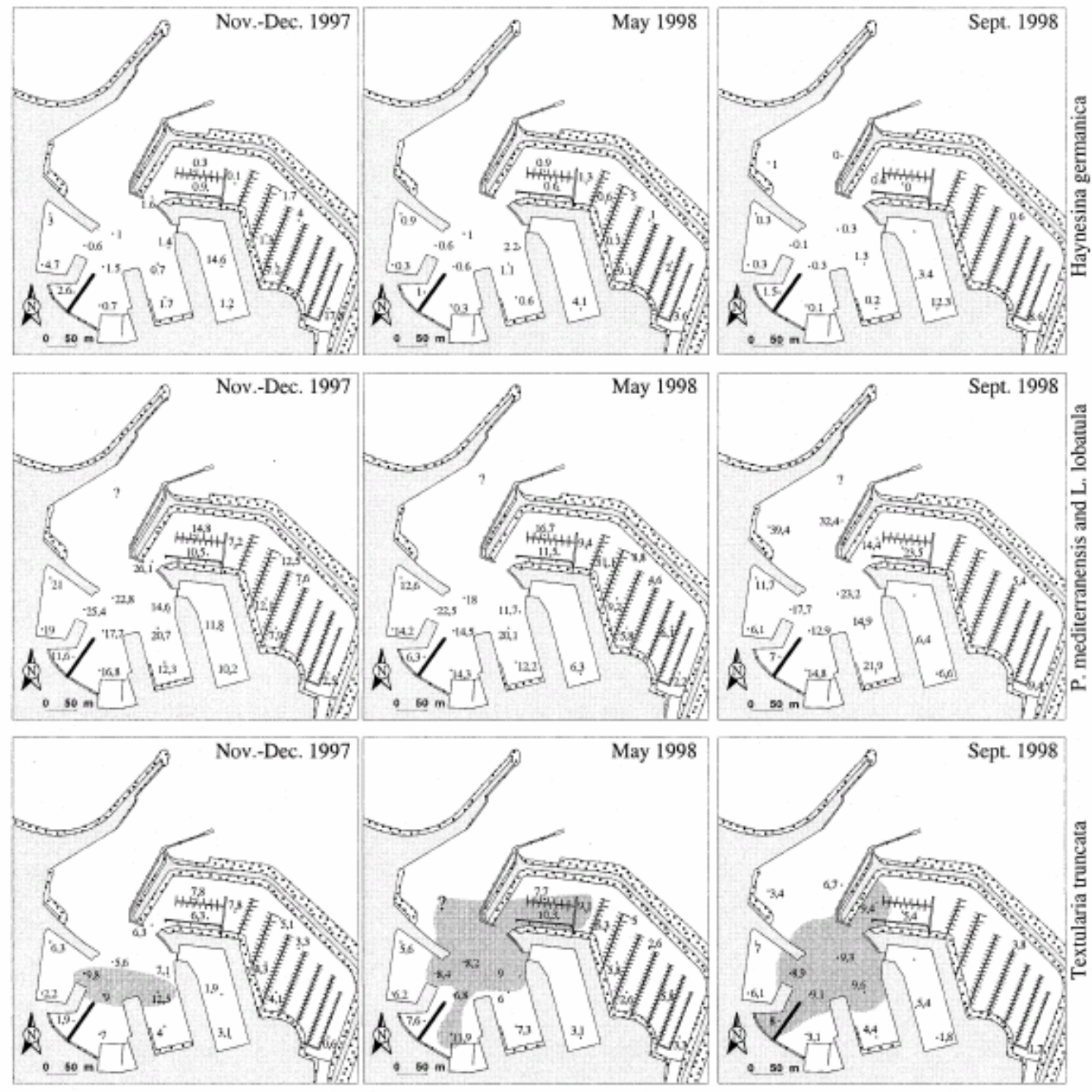

Figure 11. Relative abundance of the selected species during the three sampling periods. 


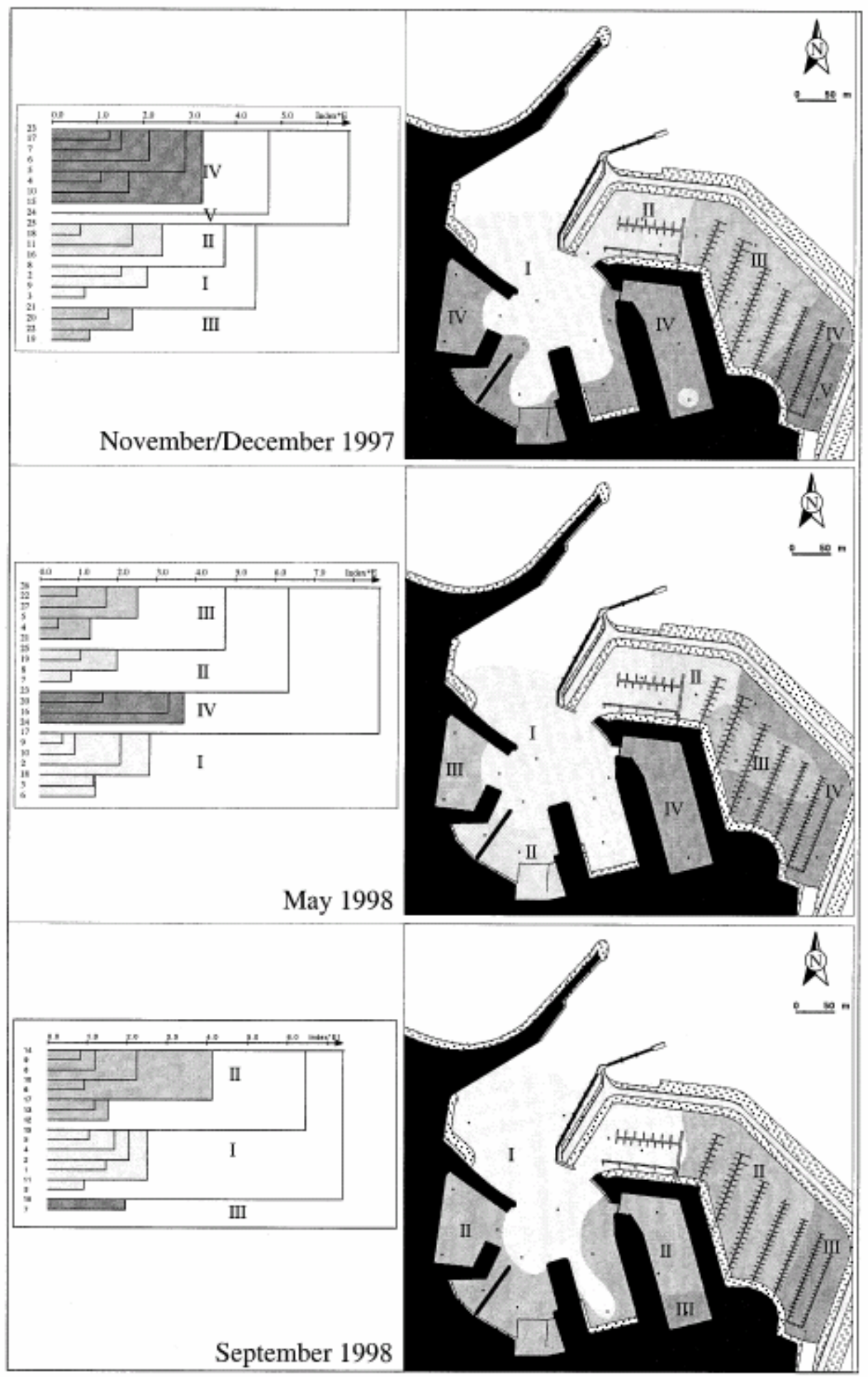

Figure 12. Q mode hierarchical analysis and mapping of the clusters distinguished during the three sampling periods. 

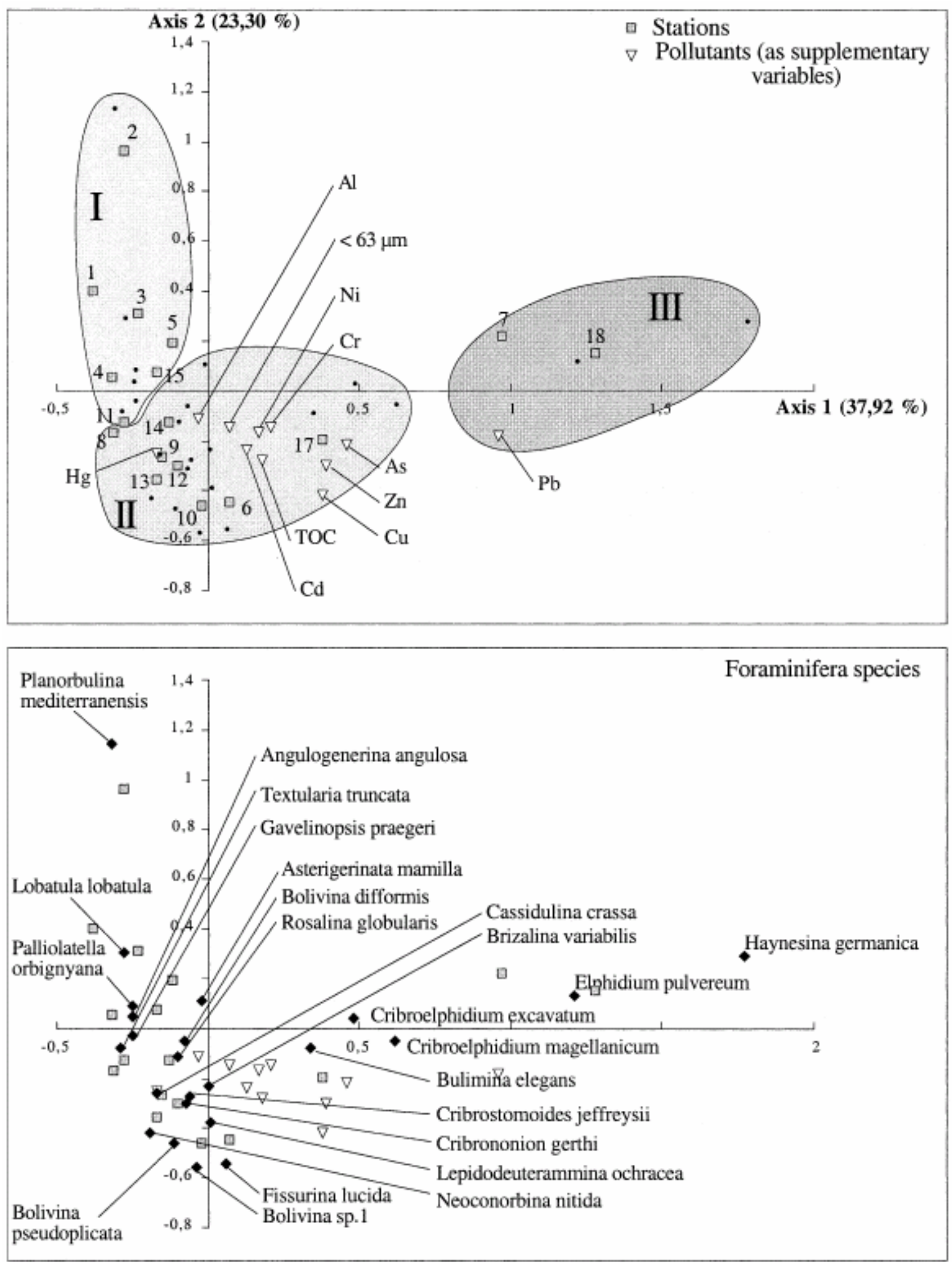

Figure 13. Factor analysis in September 1998. Distribution of the species, samples, clusters and contaminants (as supplementary variables) on the first plane (1-2). 

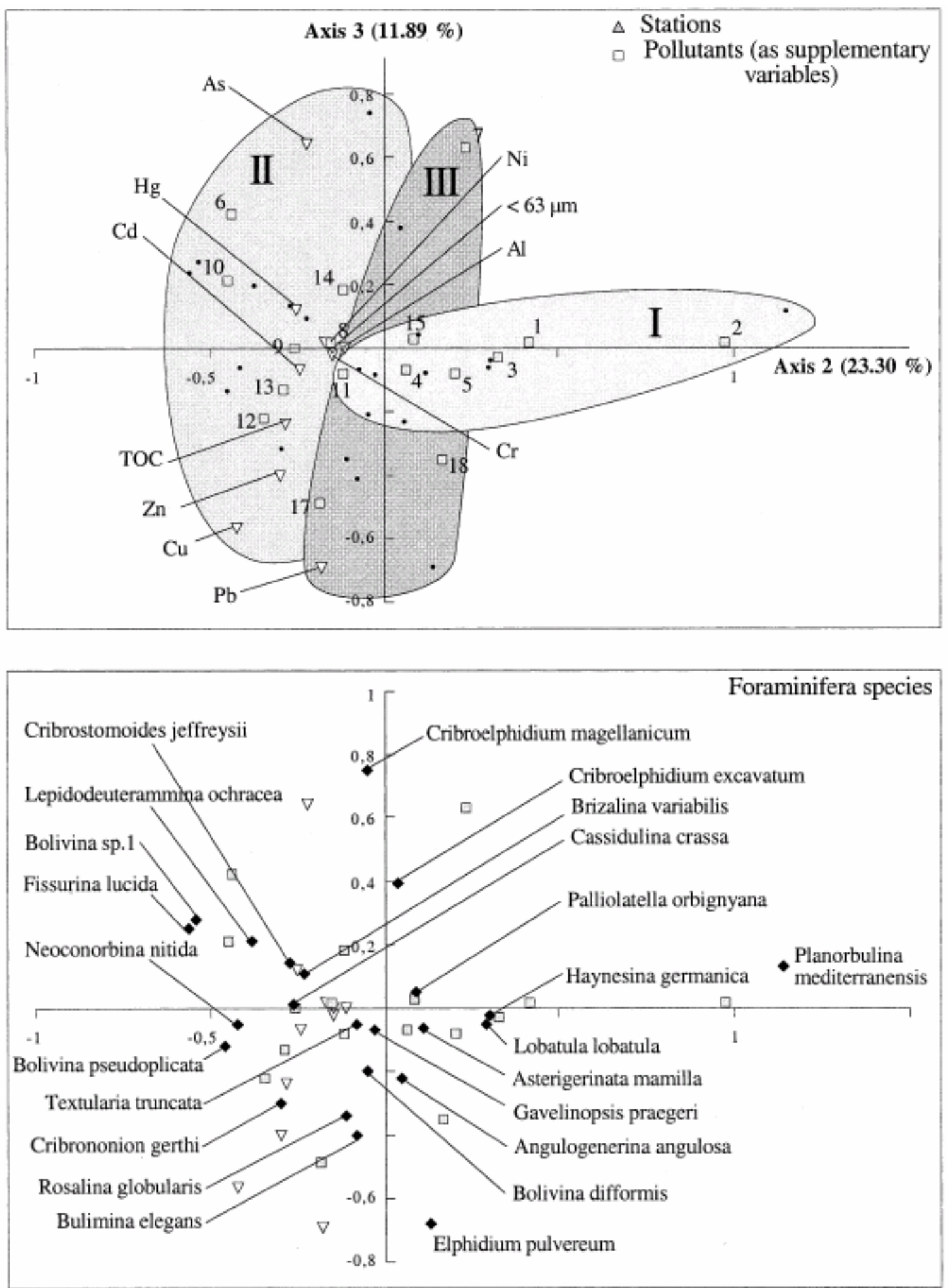

Figure 14. Factor analysis in September 1998. Distribution of the species, samples, clusters and contaminants (as supplementary variables) on the second plane (2$3)$. 


\section{Plate}

PLATE 1

Scale bar $=100 \mu \mathrm{m}$

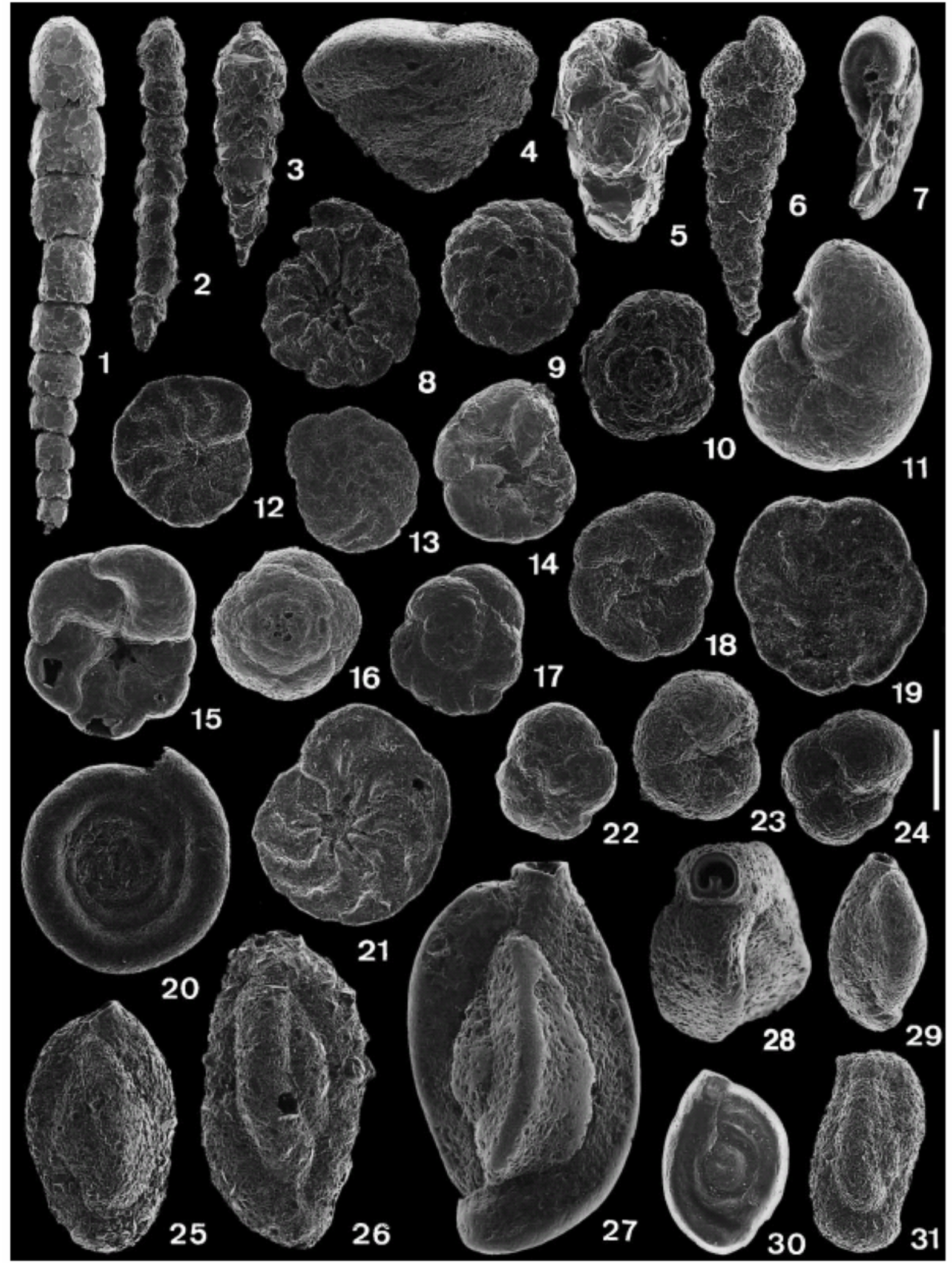

fig 1 : Leptohalysis catella, (Hoegland, 1947), st. 22, May 1998.

fig 2 : Reophax arctica, Brady, 1881, st. 25, November-December 1997.

fig 3 : Reophax nana, Rhumbler, 1911, st. 7, September 1998. 
fig 4 : Textularia truncata, Höglund, 1947, st. 5, September 1998.

fig 5 : Eggerelloides scabrus , (Williamson, 1858), st. 4, September 1998.

fig 6 : Spiroplectammina earlandi, (Parker, 1952), st. 7, September 1998.

fig 7 : Jadammina macrescens, (Brady, 1870), st. 25, November-December 1997.

fig 8 : Remaneica plicata, (Terquem, 1876), st. 12, September 1998.

fig 9 : Remaneica plicata, (Terquem, 1876), st. 12, September 1998.

fig 10 : Deuteramina eddystonensis, Brönnimann \& Whittaker, 1990, st. 25, NovemberDecember 1997.

fig 11 : Cribrostomoides jeffreysii, (Williamson, 1858), st. 13, September 1998.

fig 12 : Lepidodeuteramina ochracea, (Williamson, 1858), st. 7, September 1998.

fig 13 : Lepidodeuteramina ochracea, (Williamson, 1858), st. 7, September 1998.

fig 14 : Deuteramina eddystonensis, Brönnimann \& Whittaker, 1990, st. 25, NovemberDecember 1997.

fig 15 : Paratrochammina cf. haynesi, (Atkinson, 1969), st. 4, September 1998.

fig 16 : Paratrochammina cf. haynesi, (Atkinson, 1969), st. 4, September 1998.

fig 17 : Deuteramina eddystonensis, Brönnimann \& Whittaker, 1990, st. 25, NovemberDecember 1997.

fig 18 : Deuteramina eddystonensis, Brönnimann \& Whittaker, 1990, st. 25, NovemberDecember 1997.

fig 19 : Paratrochammina sp., st. 13, September 1998.

fig 20 : Ammodiscus planorbis , Höglund, 1947, st. 3, May 1998.

fig 21 : Lepidodeuteramina ochracea, (Williamson, 1858), st. 7, September 1998.

fig 22 : Portatrochammina murrayi, Brönnimann \& Zaninetti, 1984, st. 13, September 1998.

fig 23 : Portatrochammina murrayi, Brönnimann \& Zaninetti, 1984, st. 13, September 1998.

fig 24 : Portatrochammina murrayi, Brönnimann \& Zaninetti, 1984, st. 13, September 1998.

fig 25 : Siphonaperta aspera, (d'Orbigny, 1826), st. 2, September 1998.

fig 26 : Siphonaperta cf. anguina arenata (Said, 1949), st. 4, September 1998.

fig 27 : Siphonaperta quadrata, (Norvang, 1945), st. 3, November-December 1997.

fig 28 : Siphonaperta quadrata, (Norvang, 1945), st. 3, November-December 1997.

fig 29 : Siphonaperta aspera, (d'Orbigny, 1826), st. 2, September 1998.

fig 30 : Spiroloculina depressa, d'Orbigny, 1846, st. 2, September 1998.

fig 31 : Siphonaperta sp., st. 4, September 1998. 
PLATE 2

Scale bar $=100 \mu \mathrm{m}$, except for Massilina secans $($ scale bar $=300 \mu \mathrm{m})$

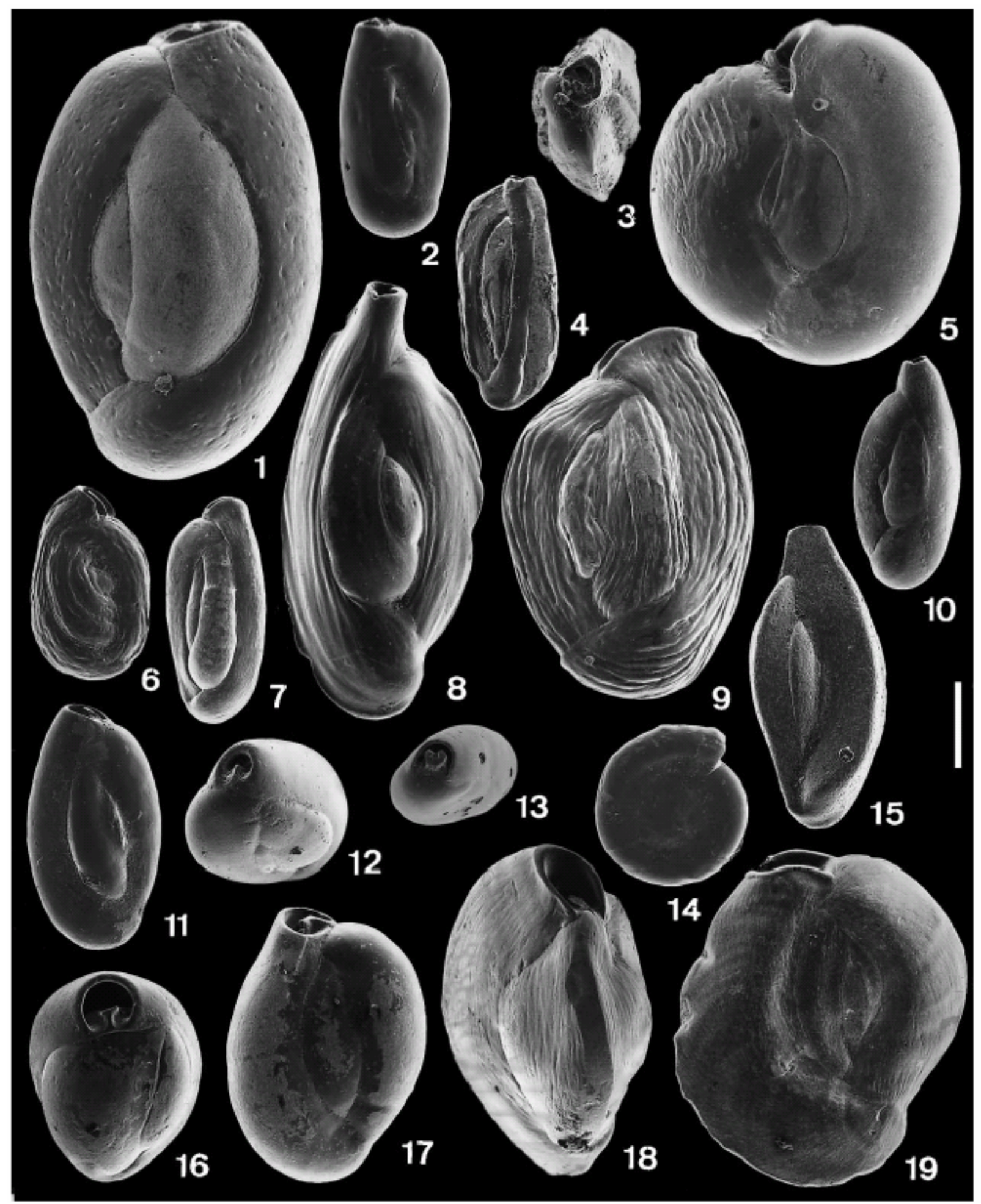

fig 1 : Quinqueloculina dunkerquiana, (Heron-Allen \& Earland, 1930), st. 25, NovemberDecember 1997.

fig 2 : Quinqueloculina lata, Terquem, 1876, st. 7, September 1998.

fig 3 : Quinqueloculina stelligera, Schlumberger, 1893, st. 9, September 1998.

fig 4 : Quinqueloculina stelligera, Schlumberger, 1893, st. 9, September 1998.

fig 5 : Miliolinella subrotunda, (Montagu, 1803), st. 7, September 1998.

fig 6 : Sigmoilina ? sp., st. 5, September 1998. 
fig 7 : Lachlanella sp., st. 1, September 1998.

fig 8 : Adelosina sp., st. 11, November-December 1997.

fig 9 : Lachlanella undulata, (d'Orbigny, 1852), st. 2, November-December 1997.

fig 10 : Adelosina longirostra, (d'Orbigny, 1826), st. 25, November-December 1997.

fig 11 : Quinqueloculina seminula, (Linné, 1758), st. 7, September 1998.

fig 12 : Quinqueloculina seminula, (Linné, 1758), st. 7, September 1998.

fig 13 : Triloculina williamsoni, Terquem, 1878, st. 8, September 1998.

fig 14 : Cornuspira involvens, (Reuss, 1850), st. 2, November-December 1997.

fig 15 : Edentostomina sp., st. 2, September 1998.

fig 16 : Triloculina trigonula, (Lamarck, 1804), st. 2, September 1998.

fig 17 : Triloculina trigonula, (Lamarck, 1804), st. 2, September 1998.

fig 18 : Quinqueloculina trigonula, Terquem, 1876, st. 26, May 1998.

fig 19 : Massilina secans, (d'Orbigny, 1826), st. 5, September 1998. 
PLATE 3

Scale bar $=100 \mu \mathrm{m}$

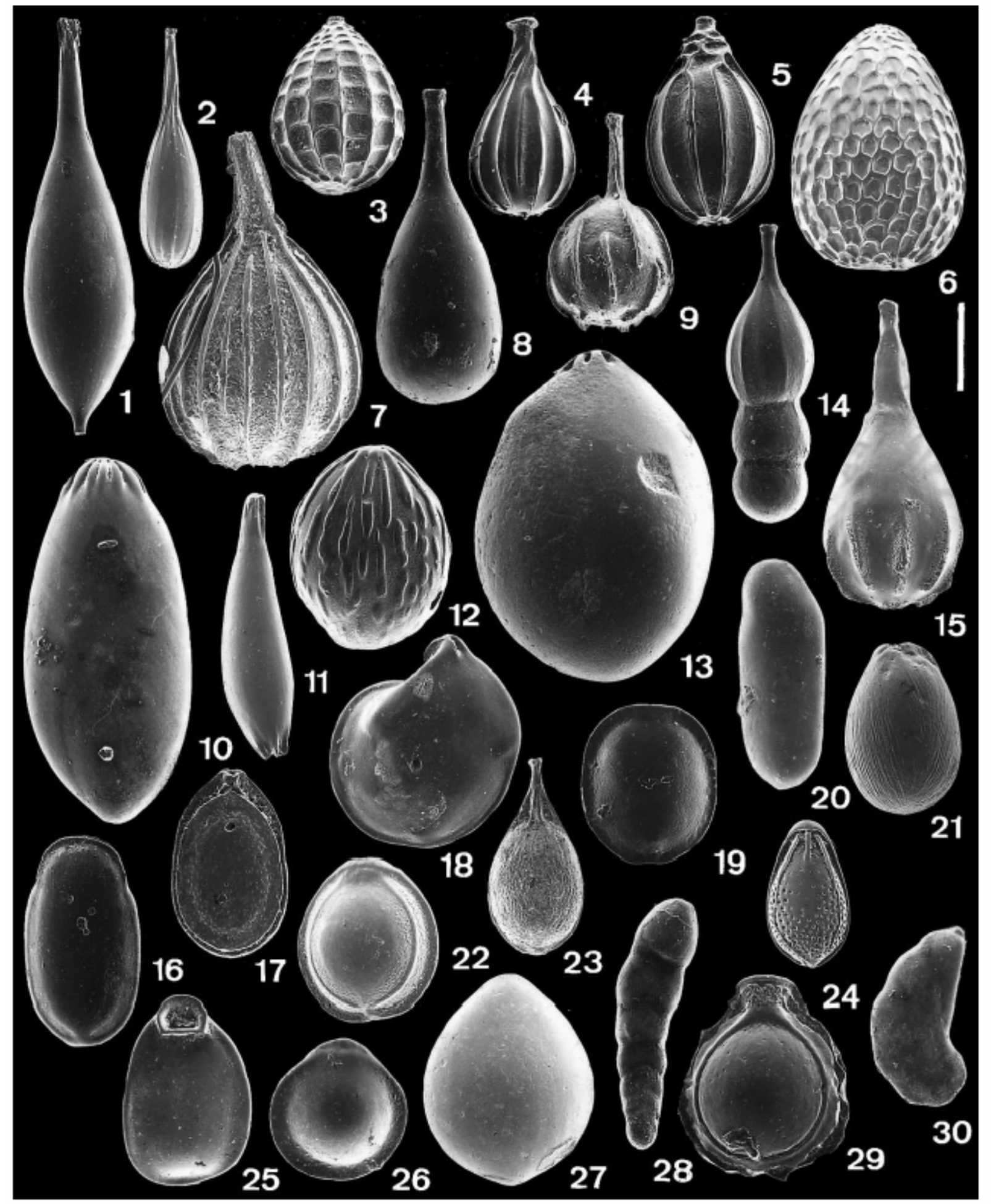

fig 1 : Hyalinonetrion clavatum, (Williamson, 1846), st. 4, May 1998.

fig 2 : Lagena laevis, (Montagu, 1803), st. 4, September 1998.

fig 3 : Favulina melo, (d'Orbigny, 1839), st. 2, September 1998.

fig 4 : Lagena sulcata spirata, Bandy 1959, st. 25, November-December 1997.

fig 5 : Homalohedra williamsoni, (Alcock, 1865), st. 4, September 1998.

fig 6 : Favulina squamosa, (Montagu, 1803), st. 4, September 1998.

fig 7 : Lagena sulcata (Walker \& Jacob, 1798), st. 4, September 1998. 
fig 8 : Lagena laevis, (Montagu, 1803), st. 4, September 1998.

fig 9 : Lagena sp., st. 25, November-December 1997.

fig 10 : Polymorphina sp., st. 4, September 1998.

fig 11 : Procerolagena cf. implicata, (Williamson, 1858), st. 4, September 1998.

fig 12 : Globulina myristiformis, (Williamson, 1858), st. 25, November-December 1997.

fig 13 : Globulina gibba, (d'Orbigny, 1826), st. 3, September 1998.

fig 14 : Pyramidula catesbyi (d'Orbigny, 1839), st. 10, September 1998.

fig 15 : Lagena semistriata, Williamson, 1848, st. 3, September 1998.

fig 16 : Fissurina subquadrata, Parr, 1945, st. 8, November-December 1997.

fig 17 : Lagenosolenia lagenoides, (Williamson, 1858), st. 3, September 1998.

fig 18 : Lenticulina rotulata, (Lamarck, 1804), st. 2, September 1998.

fig 19 : Fissurina sp., st. 2, September 1998.

fig 20 : Polymorphina sp., st. 4, September 1998.

fig 21 : Favulina lineata, (Williamson, 1848), st. 2, September 1998.

fig 22 : Fissurina fasciata carinata (Sidebottom, 1906), st. 2, September 1998.

fig 23 : Vasicostella sp., st. 5, September 1998.

fig 24 : Fissurina semimarginata (Reuss, 1870), st. 2, September 1998.

fig 25 : Parafissurina inaequilateralis, (Wright, 1886), st. 8, November-December 1997.

fig 26 : Parafissurina sp., st. 4, September 1998.

fig 27 : Fissurina lucida, (Williamson, 1848), st. 4, September 1998.

fig 28 : Alfredosilvestris sp., st. 3, November-December 1997.

fig 29 : Palliolatella orbignyana, (Seguenza, 1862), st. 4, September 1998.

fig 30 : Astacolus crepidulus, (Fichtel \& Moll, 1798), st. 4, November-December 1997. 
PLATE 4

Scale bar $=100 \mu \mathrm{m}$

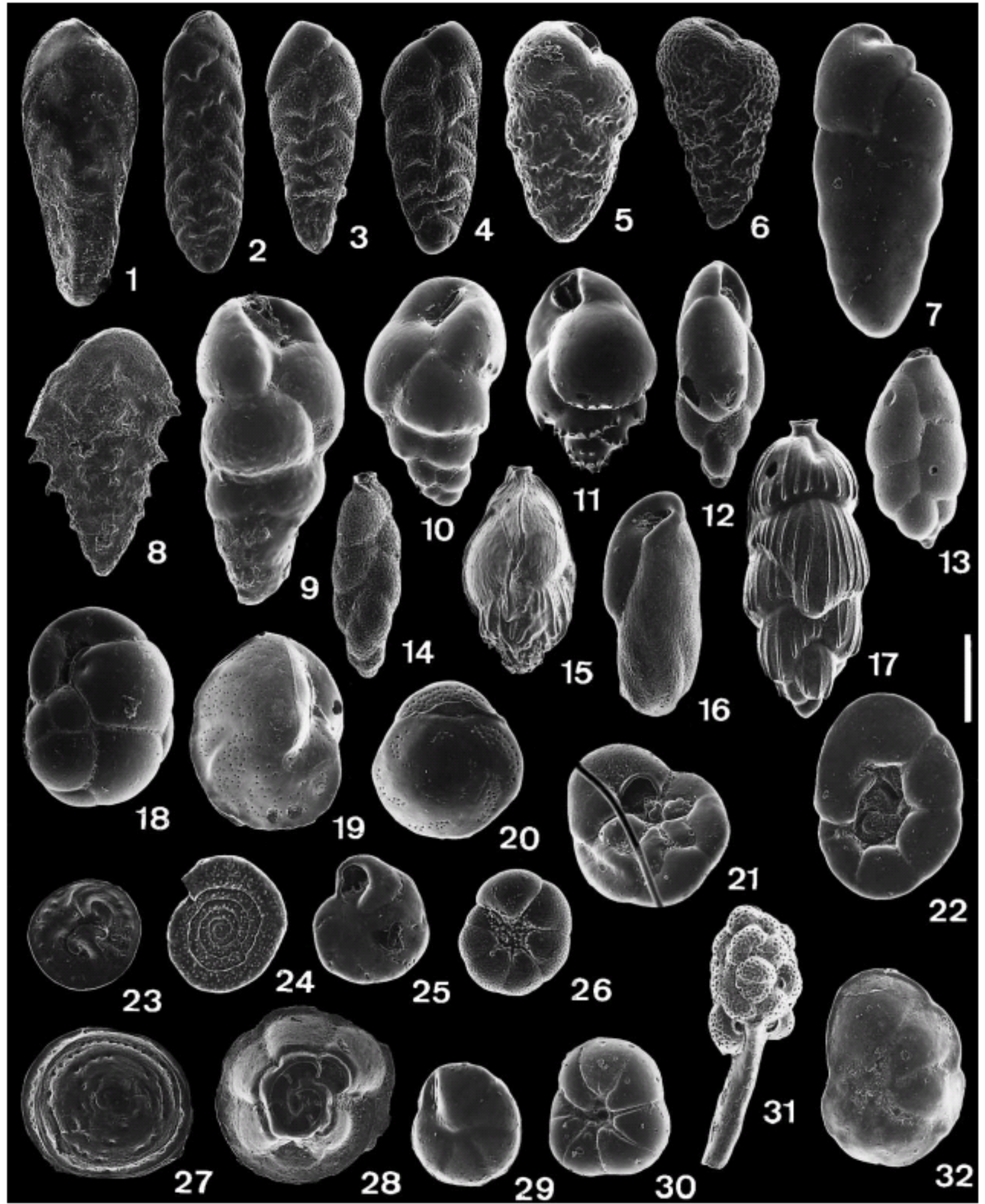

fig 1 : Brizalina spathulata, (Williamson, 1858), st. 4, September 1998.

fig 2 : Bolivina sp., st. 4, September 1998.

fig 3 : Bolivina variabilis, (Williamson, 1858), st. 4, September 1998.

fig 4 : Bolivina variabilis, (Williamson, 1858), st. 4, September 1998.

fig 5 : Bolivina cf. robusta, Brady, 1884, st. 4, September 1998.

fig 6 : Bolivina pseudoplicata, Heron-Allen \& Earland, 1930, st. 4, September 1998.

fig 7 : Bolivina sp. 1, st. 2, September 1998.

fig 8 : Bolivina difformis, (Williamson, 1858), st. 4, September 1998. 
fig 9 : Bulimina elongata, d'Orbigny, 1846, st. 2, September 1998. fig 10 : Bulimina elegans, d'Orbigny, 1826, st. 4, September 1998. fig 11 : Bulimina marginata, d'Orbigny, 1826, st. 4, September 1998. fig 12 : Stainforthia cf. concava, Höglund, 1947), st. 17, November-December 1997. fig 13 : Stainforthia fusiformis, (Williamson, 1858), st. 4, September 1998.

fig 14 : Hopkinsina atlantica, (Cushman, 1944), st. 10, May 1998.

fig 15 : Angulogerina angulosa, (Williamson, 1858), st. 4, September 1998. fig 16 : Buliminella elegantissima, (d'Orbigny, 1839), st. 4, September 1998.

fig 17 : Uvigerina peregrina, Cushman, 1923, st. 25, November-December 1997. fig 18 : Cassidulina crassa, d'Orbigny, 1839, st. 4, September 1998. fig 19 : Cassidulina laevigata, d'Orbigny, 1826, st. 4, September 1998.

fig 20 : Asterigerinata mamilla, (Williamson, 1858), st. 4, September 1998. fig 21 : Asterigerinata mamilla, (Williamson, 1858), st. 4, September 1998.

fig 22 : Lamarckina haliotidea, (Heron -Allen \& Earland, 1911), st. 4, September 1998. fig 23 : Patellina corrugata, Williamson, 1858, st. 4, September 1998.

fig 24 : Spirillina vivipara, Ehrenberg, 1843, st. 4, September 1998.

fig 25 : Rubratella intermedia, Grell, 1956, st. 5, September 1998.

fig 26 : Aubignyna planidorsa, (Atkinson, 1969), st. 4, September 1998.

fig 27 : Patellina corrugata, Williamson, 1858, st. 4, September 1998.

fig 28 : Colonimilesia obscura, McCulloch, 1977, st. 25, November-December 1997.

fig 29 : Epistominella sp., st. 13, September 1998.

fig 30 : Rotaliella sp., st. 15, September 1998.

fig 31 : Acervulina inhaerens, Schultze, 1854, st. 25, November-December 1997.

fig 32 : Lamarckina haliotidea, (Heron -Allen \& Earland, 1911), st. 4, September 1998. 
PLATE 5

Scale bar $=100 \mu \mathrm{m}$

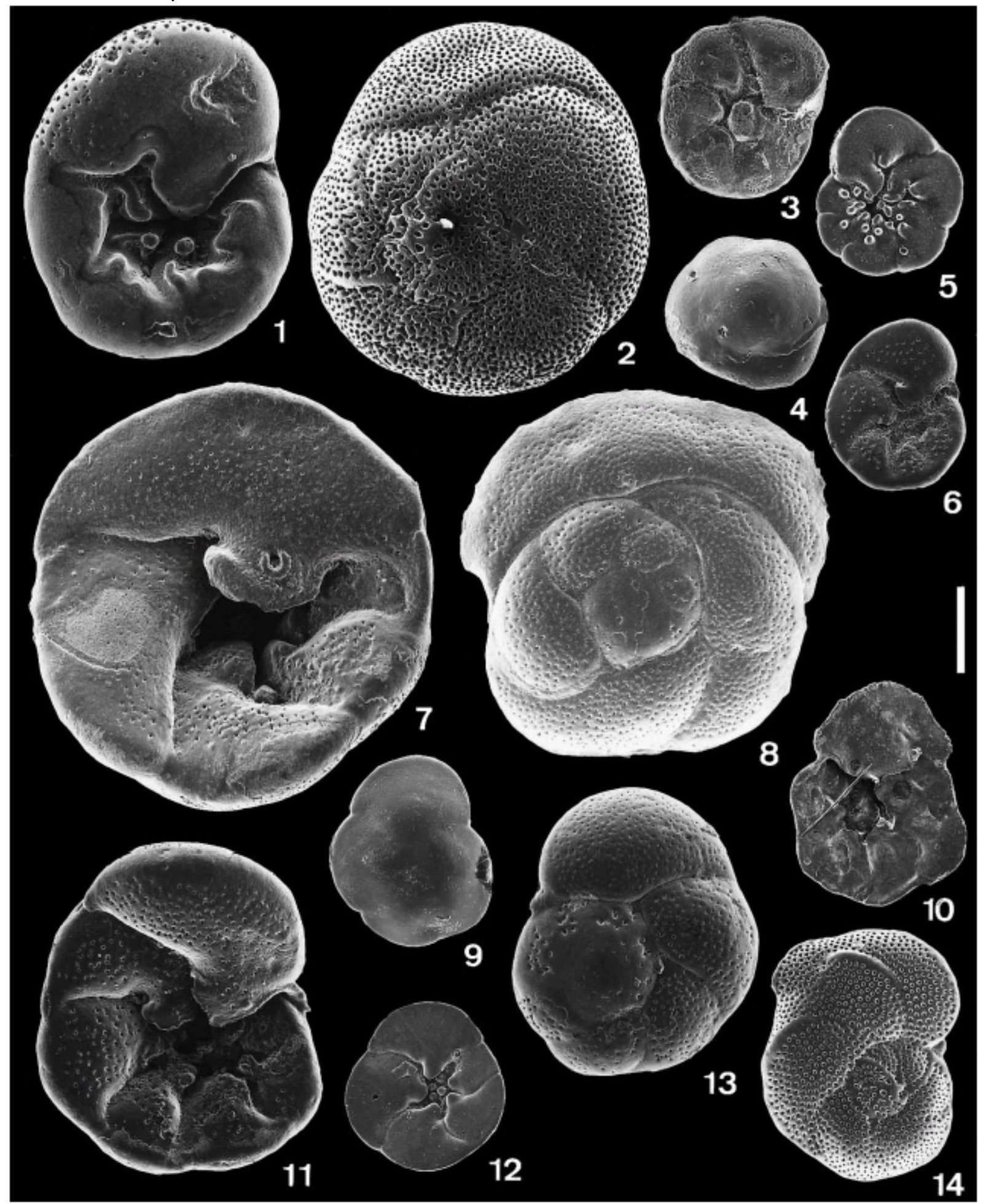

fig 1 : Rosalina bradyi, (Cushman, 1915), st. 5, September 1998.

fig 2 : Rosalina bradyi, (Cushman, 1915), st. 5, September 1998.

fig 3 : Gavelinopsis praegeri, (Heron -Allen \& Earland, 1913), st. 4, September 1998.

fig 4 : Gavelinopsis praegeri, (Heron -Allen \& Earland, 1913), st. 4, September 1998.

fig 5 : Neoconorbina milletti, (Wright, 1911), st. 14, September 1998.

fig 6 : Rosalina vilardeboana, (d'Orbigny, 1839), juvenile, st. 4, September 1998.

fig 7 : Neoconorbina terquemi, (Rzehak, 1888), st. 2, September 1998.

fig 8 : Neoconorbina terquemi, (Rzehak, 1888), st. 2, September 1998. 
fig 9 : Neoconorbina nitida, (Williamson, 1858), st. 4, September 1998.

fig 10 : Rosalina anglica, (Cushman, 1931), st. 5, September 1998.

fig 11 : Rosalina vilardeboana, (d'Orbigny, 1839), st. 4, September 1998.

fig 12 : Neoconorbina nitida, (Williamson, 1858), st. 4, September 1998.

fig 13 : Rosalina globularis, d'Orbigny, 1826, st. 4, September 1998.

fig 14 : Rosalina anglica, (Cushman, 1931), st. 5, September 1998. 


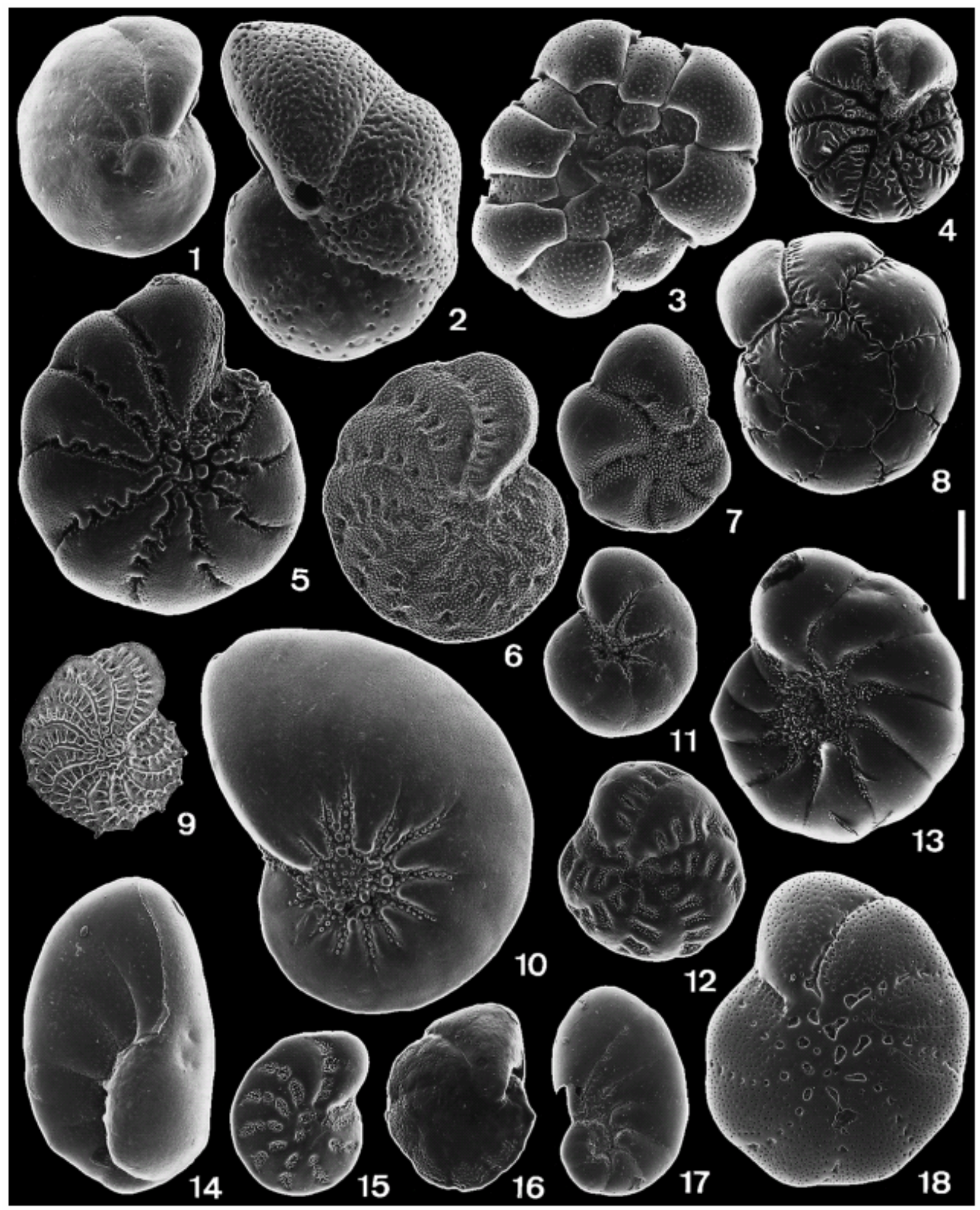

fig 1 : Cibicides refulgens, Montfort, 1808, st. 5, September 1998.

fig 2 : Lobatula lobatula, (Walker \& Jacob, 1798), st. 4, September 1998.

fig 3 : Planorbulina mediterranensis, d'Orbigny, 1826, st. 4, September 1998.

fig 4 : Ammonia beccarii, (Linné, 1758), st. 2, September 1998.

fig 5 : Cribroelphidium excavatum, (Terquem, 1876), st. 4, September 1998.

fig 6 : Elphidium pulvereum, Todd, 1958, st. 17, September 1998.

fig 7 : Cribroelphidium magellanicum, (Heron-Allen \& Earland, 1932), st. 4, September 1998. fig 8 : Ammonia beccarii, (Linné, 1758), st. 2, September 1998. 
fig 9 : Elphidium aculeatum, (d'Orbigny, 1846), st. 2, September 1998.

fig 10 : Nonion communis, (d'Orbigny, 1825), st. 24, November-December 1997.

fig 11 : Haynesina germanica, (Ehrenberg, 1840), st. 4, September 1998.

fig 12 : Cribroelphidium williamsoni, (Haynes, 1973), st. 4, September 1998.

fig 13 : Haynesina depressula, (Walker \& Jacob, 1798), st. 2, September 1998.

fig 14 : Nonionella turgida, (Williamson, 1858), st. 25, November-December 1997.

fig 15 : Cribrononion gerthi, (Van Voorthuysen, 1957), st. 4, September 1998.

fig 16 : Nonion pauperatum, (Balkwill \& Wright, 1885), st. 5, September 1998.

fig 17 : Pseudononion atlanticum, (Cushman, 1947), st. 7, September 1998.

fig 18 : Cribroelphidium cuvillieri, (Lévy, 1966), st. 4, September 1998. 


\section{APPENDICES}

Appendix 1. Relative abundance of the species collected in November-December 1997.

\begin{tabular}{|c|c|c|c|c|c|c|c|c|c|c|c|c|c|c|c|c|c|c|c|c|c|}
\hline \multicolumn{22}{|l|}{ November-December 1997} \\
\hline no. sample & 2 & 3 & 4 & 5 & 6 & 7 & 8 & 9 & 10 & 11 & 15 & 16 & 17 & 18 & 19 & 20 & 21 & 22 & 23 & 24 & 25 \\
\hline no. speciments $/ 50 \mathrm{~cm}^{3}$ & 1000 & 500000 & & & & & & & & & & & & & & & 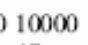 & 10000 & 015000 & 10000 & 03000 \\
\hline no. species & 59 & 57 & 40 & 40 & 42 & 45 & 48 & 46 & 48 & 52 & 46 & 48 & 55 & 82 & 74 & 53 & 47 & 39 & 71 & 57 & 101 \\
\hline Acervulina inhaerens & - & - & - & - & - & - & - & - & - & - & - & - & - & - & - & - & - & - & - & - & 0.0 \\
\hline Adelosina longirastra & - & - & - & - & - & - & - & - & - & - & - & - & - & - & - & - & - & - & - & - & 0.0 \\
\hline Adelosina partschi & - & - & - & - & - & - & - & - & - & - & - & - & - & - & - & - & - & - & - & - & 0.0 \\
\hline Adelosina sp. & - & - & - & - & - & - & - & - & - & 0.0 & - & - & - & - & - & - & - & - & 0.0 & - & - \\
\hline Alfredosilvestris sp. & - & 0.0 & - & - & - & - & - & - & - & - & - & - & - & - & - & - & - & - & - & - & - \\
\hline Ammodiscus planorbis & - & - & - & - & - & - & - & - & - & - & - & - & - & 0.0 & - & - & - & - & - & - & - \\
\hline Ammonia beccarii & - & - & - & - & 0.3 & - & - & - & - & - & - & - & - & 0.3 & - & - & - & - & - & - & - \\
\hline Ammonia tepida & - & - & - & - & - & - & - & - & - & - & 0.3 & - & 0.3 & - & - & - & 0.3 & - & - & 0.4 & - \\
\hline Amphicoryna scalaris & - & - & - & - & - & - & - & - & 0.3 & - & - & - & - & 0.0 & 0.0 & - & - & - & - & - & - \\
\hline Angulogerina angulas a & 0.3 & 1.6 & 3.0 & 1.9 & 0.6 & - & 0.3 & 1.6 & 1.3 & 1.8 & 0.6 & 1.5 & 0.3 & 1.8 & 1.6 & 0.7 & 1.5 & 0.9 & 0.6 & 0.9 & 0.3 \\
\hline Astacol & - & - & 0.0 & - & - & 0.3 & - & - & - & - & - & 0.2 & - & 0.0 & 0.0 & - & - & - & - & - & - \\
\hline Asterigerinat a mamilla & 0.3 & 1.9 & 1.5 & 3.2 & 3.0 & 0.6 & 0.7 & 2.3 & 2.0 & 0.4 & 2.2 & 1.2 & 2.6 & 0.9 & 1.3 & 0.3 & 1.8 & 1.2 & 0.6 & - & 0.6 \\
\hline Asterc & - & - & - & - & - & - & - & - & - & - & - & - & - & - & - & - & - & - & 0.3 & - & - \\
\hline Aubignyna planidor: & 1.0 & - & 3.0 & 13 & 0.9 & 0.3 & 0.3 & 0.3 & 2.3 & - & 0.6 & 1.7 & 0.9 & 0.3 & 1.3 & 1.7 & 2.5 & 3.4 & 4.4 & ${ }^{2} 6.2$ & 19 \\
\hline Bolivina cf. B. psetl & - & - & - & - & - & - & - & - & - & - & - & - & - & - & - & - & 0.8 & - & - & - & - \\
\hline Bolivina diffom & 1.0 & 0.6 & 1.2 & 0.9 & - & 0.3 & 0.3 & 0.7 & 0.7 & 0.7 & - & 2.2 & 1.1 & 0.3 & 0.9 & 1.1 & 1.6 & 0.7 & 0.6 & - & 0.3 \\
\hline Bolivi & 4.6 & 1.6 & 0.6 & 2.5 & 3.0 & 1.6 & 3.2 & 2.3 & 0.7 & 6.0 & 3.4 & 4.1 & 4.6 & 2.7 & 5.2 & 5.6 & ${ }^{3} 8.4$ & 5.8 & 5.7 & 2.5 & 3.6 \\
\hline Bolivina st & 7.3 & 2.5 & 11.4 & 6.6 & 7.8 & 11.9 & 7.5 & 4.9 & 6.3 & 4.9 & 4.4 & 7.2 & 12.6 & 5.2 & 11.9 & 1.1 & 7.4 & 17.6 & 11.6 & 12.9 & 9.4 \\
\hline Boliv & - & 0.3 & - & - & - & - & - & - & - & - & - & - & 0.3 & - & 0.3 & 0.3 & 1.3 & - & 0.3 & - & 0.6 \\
\hline Brizal & 0.3 & - & 0.3 & 1.6 & - & 0.6 & 0.3 & 0.0 & - & 0.4 & - & - & ${ }^{4} 0.3$ & ${ }^{20}$ & ${ }^{2} 0$ & ${ }^{2} 0.3$ & ${ }^{20}$ & ${ }^{2} 0$ & ${ }^{2} 0$ & ${ }^{2} 0$ & 0.0 \\
\hline & 3. & 2.2 & 1.5 & 8.5 & 6.6 & 16.5 & ${ }^{2} 9.6$ & 7.9 & 11.0 & 0.7 & 7.5 & 1.4 & 5.7 & 2.7 & 7.8 & 7.8 & ${ }^{\mathrm{a}} 1.5$ & "11.6 & 8.2 & 7.7 & 6.2 \\
\hline & 0. & 0.3 & 1.2 & 2.2 & 3.0 & 1.3 & ${ }^{4} 0.7$ & 1.0 & 1.0 & 1.6 & 1.2 & 0.5 & ${ }^{\mathrm{a}} 1.7$ & 0.9 & 0.3 & 2.2 & 1.3 & ${ }^{2} 0$ & 0.3 & "15.8 & 0.6 \\
\hline Bulim & 0. & - & - & - & - & - & - & - & - & - & - & - & - & - & - & - & - & - & - & - & - \\
\hline & 1.0 & 0.3 & 0.0 & 0.3 & - & - & 1.7 & 1.3 & 2.3 & 0.0 & - & 1.5 & 0.9 & 0.5 & 0.3 & 0.3 & ${ }^{\mathrm{a}} 1.5$ & 0.9 & 0.0 & ${ }^{2} 0.9$ & 0.3 \\
\hline Bulin & - & 0.0 & 0.0 & - & - & - & - & - & - & - & - & - & 0.0 & - & 0.3 & - & - & - & - & - & 0.0 \\
\hline & 0.3 & - & - & - & - & - & - & - & - & - & - & 0.2 & - & - & - & - & - & - & - & - & - \\
\hline & 5 & 3.2 & 5.9 & 6.1 & 1.8 & 3.5 & 4.3 & 2.6 & 7.0 & 1.8 & 0.6 & 2.4 & 2.0 & 3.2 & 4.4 & 4.4 & 6.3 & 4.3 & 4.7 & 4.9 & 2.2 \\
\hline & 1. & 0.3 & 0.3 & 09 & 0.3 & - & 0.3 & - & 0.3 & - & - & - & 0.0 & 0.9 & 0.3 & 0.3 & - & 0.3 & 0.6 & - & 0.6 \\
\hline & 0. & - & - & - & - & - & - & - & - & - & - & - & - & - & - & - & - & - & - & - & - \\
\hline Colonimilesic & - & - & - & - & - & - & - & - & - & - & - & - & - & - & - & - & - & - & - & - & 0.0 \\
\hline & - & - & - & - & - & - & - & & - & - & - & - & - & & - & - & - & & - & 0.0 & \\
\hline & - & 0.3 & - & - & - & - & - & ${ }^{2} 0$ & - & - & - & 0.2 & - & 0.0 & 0.0 & 0.3 & 0.0 & - & 0.0 & - & 0.3 \\
\hline Crib & 5.3 & 1.9 & 1.8 & 4.7 & 3.3 & 2.6 & 2.3 & 2.3 & 4.0 & 4.6 & 3.4 & 5.8 & 2.3 & 4.3 & 2.2 & 1.7 & 1.5 & 0.0 & 2.5 & 0.9 & 2.7 \\
\hline $\begin{array}{c}\text { Cribroelphidium } \\
\text { magellanicum }\end{array}$ & - & 0.6 & 0.9 & 1.6 & 3.0 & 1.3 & 0.3 & 1.3 & 2.0 & 2.8 & 1.6 & 1.2 & 1.4 & 0.5 & 0.3 & 1.3 & 1.8 & 0.7 & 1.6 & 0.9 & 0.9 \\
\hline Cribroelphidium williamso & 1.0 & 1.0 & 0.9 & 0.3 & 1.2 & 0.0 & 0.7 & 1.0 & - & 2.8 & - & - & 0.3 & 1.8 & 0.9 & 0.3 & - & 0.0 & 0.3 & - & 0.3 \\
\hline & 0. & 1.6 & 0.9 & 1.6 & 1.5 & 0.3 & 1.7 & 1.0 & 1.0 & 0.0 & 3.7 & 1.9 & 2.0 & & & - & 2.3 & 1.2 & 1.3 & 0.4 & \\
\hline Cribt & - & - & - & - & - & - & $a_{0}$ & - & - & - & - & - & - & - & - & - & - & - & - & 0.6 & - \\
\hline Cribrostomoides jeffreysii & 1.3 & 2.5 & - & - & 0.3 & - & 1.7 & 0.3 & 0.3 & 0.7 & 0.3 & - & 0.3 & 3.0 & 1.3 & 2.4 & 1.5 & - & 0.3 & - & 2.2 \\
\hline$C$ colofurio of $C$, & & & & & & & & & - & - & - & - & & & & - & - & - & - & 0.0 & 0.6 \\
\hline
\end{tabular}


Appendix A (continued)

November-December 1997

no. sample

$\begin{array}{llllllllllllllllllllll}2 & 3 & 4 & 5 & 6 & 7 & 8 & 9 & 10 & 11 & 15 & 16 & 17 & 18 & 19 & 20 & 21 & 22 & 23 & 24 & 25\end{array}$

Cyclogira sp.

Dentalina sp.

Deuterammina sp.

Discorbinella bertheloti

Discorbinella sp.

Discorbinella sp. juv.

Edentostomina cultrate

Eggerelloides scabrous

Elphidium aculeatum

Elphidium crispum

Elphidium macellum

Elphidium pudvereum

Elphidium sp.

Elphidium sp. juv.

Epistominella sp.

Favulina hexagona

Favulina melo

Favulina squamosa

Fissurina lucida

Fissurina marginata

Fissurina sp.2

Fissurina subquadrat

Gavelinapsis pradrata

Globulina gibba

Globulina myristifomis

Glomospira sp.

Homalohedra williamsoni

Hanzawaia sp.

Haynesina depressula

Haynesina gemanica

Hyalinonetrion clavatum

Jadammina polystoma

Lachlanella sp.

Lachlanella undulata

Lagena laevis

Lagena semistriata

Lagena sp.

Lagena striata

Lagena sulcata var.

laevicostata

Lagena sulcata var. spirata

Lagenosolenia cf. Lelliptica

$\overline{0.0}$

$-$

$\overline{0} 0.3-0.0-0.3$

$-\quad-$

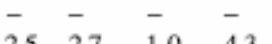

$\begin{array}{llllllllll}2.5 & 2.7 & 1.0 & 4.3 & 0.3 & 2.0 & 1.8 & 14.2 & 5.8 & 1.1\end{array}$

$\begin{array}{lllllllllllll}0.7 & 1.3 & 3.0 & \overline{2} .8 & \overline{1.5} & \overline{2.3} & 0.7 & - & - & - & - & - & - \\ -\end{array}$

$\begin{array}{lllllllllllllllll}- & - & 0.3 & - & - & - & - & - & - & - & - & 0.2 & - \\ - & - & - & - & 0.3 & - & - & - & 0.0 & 0.7 & 0.0 & 0.2 & 0.0\end{array}$

$\begin{array}{llllllllllllllll}1.7 & 0.6 & 3.0 & 0.9 & 2.7 & 5.2 & 0 & 0.7 & 3.7 & 1.5 & 1.2 & 2.4 & 3.4 & 2.4 & 22 & 1.7\end{array}$

$\begin{array}{lllllllllllllllllllll}0.3 & 0.6 & 0.3 & 0.6 & 0.3 & 2.3 & - & 1.0 & 1.3 & 0.7 & 2.2 & - & 1.1 & 0.9 & 0.3 & 1.1 & - & 0.9 & 0.9 & 0 & 0.9\end{array}$

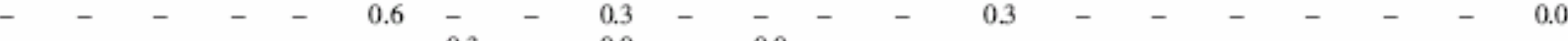

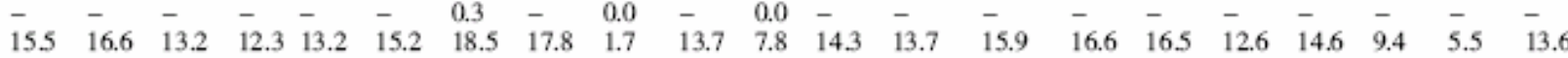

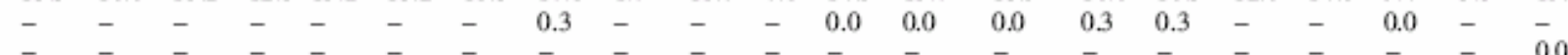

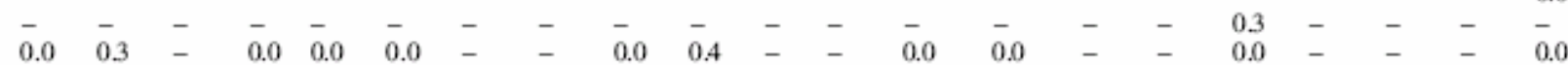

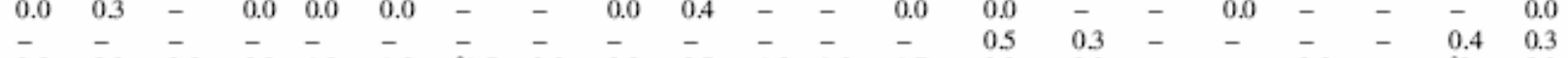

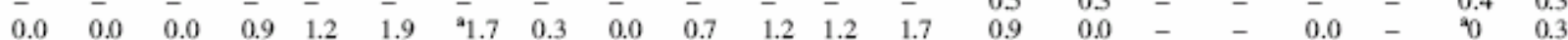

$\begin{array}{lllllllllllllllllllll}1.0 & 0.6 & 3.0 & 4.7 & 1.5 & 2.6 & 0.7 & 0.7 & 1.7 & 1.6 & 14.6 & 1.2 & 1.4 & 0.3 & 0.0 & { }^{\mathrm{a}} 1.7 & 1.3 & 4.0 & 7.2 & \mathrm{a}_{17.8} & 0.9\end{array}$

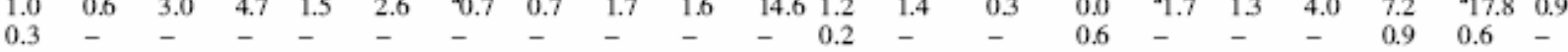

$-\quad-0.3-$

$\overline{0.0}$

$0.3-$

- $-\quad-\quad-\quad-\quad-0.3-$

$-0.3-$

$\begin{array}{lllll}0.0 & 0.3 & 0.9 & - & -\end{array}$

$-\quad-\quad-10-$

$\begin{array}{lllll}0.6 & \overline{0} 0 & \overline{0} & \overline{0.3} & \overline{0.0}\end{array}$

$0.0-$

$\overline{0.3}-0.3$

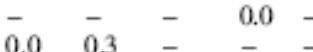

$\begin{array}{lllllll}0.6 & - & - & - & 0.9 & 0.6 & -\end{array}$

$\begin{array}{lllllll}- & - & - & - & - & - & 0.0 \\ - & - & - & - & - & - & 0.0\end{array}$

$\begin{array}{lllllll}- & - & - & - & - & - & 0.0\end{array}$

$\begin{array}{lllllllll}- & - & - & - & - & - & - & 0.0 \\ - & - & - & - & - & - & - & 0.0\end{array}$

$\begin{array}{llllllll}0.0 & 0.0 & - & - & - & 0.0 & - & 0.0 \\ 0.3 & - & - & - & - & 0.0 & - & 0.0\end{array}$
$0.0 \quad-\quad-\quad-\quad-0.0-0.0$ 
Appendix A (continued)

November-December 1997

no. sample

$\begin{array}{lllllllllllllllllllll}2 & 3 & 4 & 5 & 6 & 7 & 8 & 9 & 10 & 11 & 15 & 16 & 17 & 18 & 19 & 20 & 21 & 22 & 23 & 24 & 25\end{array}$

Lagenosolenia sp.

Lamarckina halioticulina rotulata

$-$

0.3

0.0

Leptohalysis catella

Lobatula lobatula

Massilina sp. juveniles

Miliolidae sp.

Miliolinella obliquinodus

Miliolinella subrotunda

Milliammina sp.

Neoconorbina nitida

Nonion communis.

Nonion pauperatum

Nonion sp.

Nonionella cf. N. opima

Nonionella cf.

Nonionella turgida

Palliolatella sp.

Palliolatella orbignyana

Parafissurina inaequilateralis

Parafissurina sp.

Paratrochanmina ef. $P$.

haynesi

Paratrochammina sp.

Patellina comugata

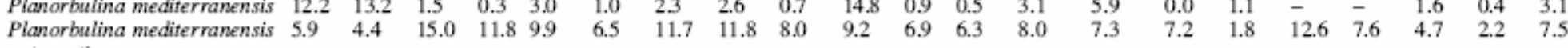

juveniles

$\begin{array}{llllllllllllllllllllllll}\text { Portatrochammina murrayi } & - & - & - & - & - & - & - & - & - & - & - & - & - & - & - & - & - & - & - & - & 0.0 \\ \text { Pseudononion at lanticum } & 0.0 & 0.6 & 0.3 & 0.3 & - & - & 0.0 & - & 0.3 & - & 0.3 & 0.2 & - & 0.5 & 0.6 & - & 0.0 & - & 1.3 & 0.4 & 0.6\end{array}$

$\begin{array}{llllllllllllllllllllll}\text { Pygmaeaseistron sp. } & - & 0.3 & - & - & - & - & - & 0.0 & - & 0.0 & - & - & 0.3 & 0.0 & 0.0 & - & - & - & - & 0.0 & - \\ \text { Quinqueloculina } \text { cf. } Q \text {. } & - & - & - & - & - & - & - & 0.3 & - & - & - & 0.2 & - & - & - & - & - & - & - & - & -\end{array}$

quatrata
Quinqueloculina dunquerkiana -

Quinqueloculina laevigata

Quinqueloculina lata

Quinqueloculina seminula

Quinqueloctitina spp.

Quinquectalina seligera

Quinqueloculina vionnensis

Remaneica plicata

Remaneicella ganzalezi

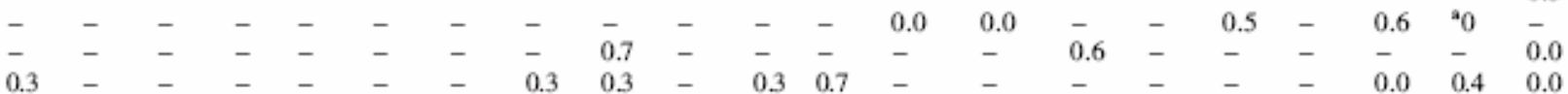

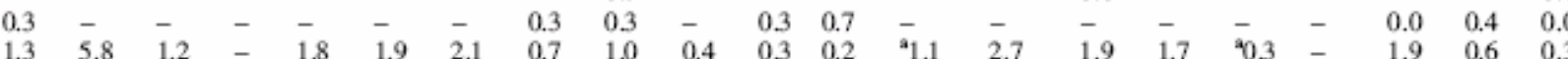

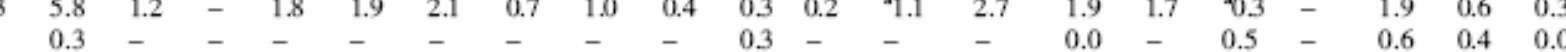

$-\quad-\quad-$ 
Appendix A (continued)

November-December 1997

\begin{tabular}{|c|c|c|c|c|c|c|c|c|c|c|c|c|c|c|c|c|c|c|c|c|c|}
\hline no. sample & 2 & 3 & 4 & 5 & 6 & 7 & 8 & 9 & 10 & 11 & 15 & 16 & 17 & 18 & 19 & 20 & 21 & 22 & 23 & 24 & 25 \\
\hline Reophax cf. R. arctica & 0.0 & - & - & - & - & - & - & - & - & - & - & - & - & 0.0 & - & - & - & - & - & - & 1.2 \\
\hline Reophax nana & 0.3 & 0.3 & - & - & - & - & ${ }^{\mathrm{a}} 0.3$ & - & - & - & - & - & 0.0 & 09 & 0.6 & 2.2 & ${ }^{\mathrm{a}} 1.8$ & - & 0.6 & 0.4 & 33 \\
\hline Rasalina bradyi & - & - & - & - & - & - & - & - & - & - & - & - & - & 0.0 & 0.0 & - & - & - & 0.0 & - & 1.2 \\
\hline Rasalina cf. $R$. vilardeboana & 0.3 & 1.9 & - & - & - & 0.3 & - & - & 0.0 & - & - & 0.2 & - & 0.3 & 0.0 & - & - & - & 0.0 & - & 0.3 \\
\hline Rasalina globularis & 1.0 & 0.6 & 0.6 & - & 1.5 & 1.9 & 1.7 & 0.7 & - & 2.8 & 0.6 & 3.1 & 1.1 & 2.2 & 0.3 & 1.3 & 0.5 & - & 2.2 & 0.6 & 19 \\
\hline Rasalina sp. & 1.3 & 1.3 & - & 0.6 & 3.0 & 0.6 & 2.1 & 2.3 & 1.0 & 1.6 & - & 0.0 & 0.3 & 1.6 & 0.0 & 0.3 & 2.3 & 1.8 & 0.6 & - & 0.9 \\
\hline Rotaliella sp. & 2.0 & - & 1.2 & 0.9 & - & 0.3 & 1.3 & 0.3 & 1.0 & 0.0 & 0.6 & 2.2 & 1.1 & 1.6 & 2.6 & 0.7 & 2.5 & 2.7 & 0.9 & 1.2 & 1.2 \\
\hline Rubratella intemedia & - & - & 0.3 & - & 0.3 & 0.3 & 0.3 & - & 2.3 & - & - & 0.2 & 0.0 & 0.5 & 0.0 & - & - & 0.9 & 0.3 & - & - \\
\hline Sigmavirgulina sp. & - & - & - & - & - & - & - & - & - & - & - & - & - & 0.0 & 0.0 & - & 0.3 & - & - & 0.6 & - \\
\hline Sigmoilina cf. S. tenuis & - & - & - & - & - & - & - & - & - & - & - & - & - & - & - & - & - & - & 0.0 & - & - \\
\hline Sigmoilina sp. & - & 0.3 & - & - & - & - & - & - & - & - & - & - & - & - & - & - & - & - & - & - & - \\
\hline Sigmomorphina sp. & - & - & - & - & - & - & - & - & - & - & - & - & - & - & - & - & - & - & - & - & 0.0 \\
\hline Sigmomonhina williamsoni & - & - & - & - & 0.3 & - & - & - & - & - & - & - & - & - & 0.3 & - & - & - & 0.0 & - & - \\
\hline Siphonaperta aspera & - & 0.3 & - & - & - & - & - & - & - & - & - & - & - & - & - & - & - & - & - & - & 0.0 \\
\hline Siphonapenta of. $S$ agglutinans & - & - & - & - & - & - & - & - & - & - & - & - & - & - & - & - & - & - & - & - & 0.0 \\
\hline Siphonapenta quadrata & - & 0.3 & - & - & - & - & - & - & - & - & - & - & - & - & - & - & - & - & - & - & - \\
\hline Spirillina vivipara & 0.3 & - & - & - & - & - & - & - & - & 0.4 & - & 0.2 & 0.3 & 0.3 & 0.9 & - & - & 0.3 & - & 0.4 & 0.0 \\
\hline Spiroloculina depressa & - & - & - & - & - & 0.0 & - & - & - & 0.0 & - & - & - & 0.3 & - & - & - & - & - & - & 0.0 \\
\hline Spirophtalmidium sp. & - & - & - & - & - & - & - & - & - & - & - & - & - & - & - & - & - & - & 0.3 & - & - \\
\hline Spiroplectinella eariandi & - & 0.3 & - & - & - & - & - & - & - & 0.0 & - & - & 0.3 & 0.5 & 0.0 & 0.0 & - & - & - & - & 1.9 \\
\hline Stainforthia of. $C$. concava & - & - & - & - & - & - & - & - & 0.3 & - & - & - & 0.3 & 0.5 & 0.6 & - & - & 0.3 & 0.3 & ${ }^{2} 0$ & 0.0 \\
\hline Stainforthia fusifomis & 0.7 & - & 0.3 & - & - & 0.6 & ${ }^{2} 0.3$ & 0.0 & 0.7 & 1.8 & 0.3 & 0.2 & 0.3 & 1.8 & 0.3 & 0.0 & - & - & 1.3 & - & 0.9 \\
\hline Textularia sp. & - & - & - & - & - & - & - & - & - & - & - & - & - & - & - & - & - & - & - & - & 0.0 \\
\hline Textularia tnuncata & 5.6 & 9.8 & 6.3 & 2.2 & 9.0 & 1.9 & 7.5 & 12.5 & 4.0 & 6.3 & 1.9 & 3.1 & 7.1 & 7.8 & 7.8 & 5.6 & 4.3 & 3.3 & 49 & 0.6 & 63 \\
\hline Triloculina oblonga & - & - & - & - & - & - & - & - & - & - & - & - & - & - & - & - & - & - & - & 0.0 & - \\
\hline Triloculina trigonula & - & - & - & - & - & - & - & - & - & - & - & - & - & 0.3 & - & - & - & - & - & - & - \\
\hline Triloculina williamsoni & - & - & - & - & - & - & - & - & - & - & - & - & - & - & - & - & - & - & - & - & 0.0 \\
\hline Trochammina sp. & - & - & - & - & - & - & - & - & - & - & - & - & 0.3 & - & 0.6 & - & - & - & 0.3 & 0.4 & 0.3 \\
\hline Uvigerina peregrina & - & - & - & - & - & - & - & - & - & - & - & - & - & - & - & - & - & - & - & - & 0.0 \\
\hline Wiesnerella auriculata & - & - & - & - & - & - & 0.0 & - & - & - & - & - & - & 0.3 & - & - & - & - & - & - & 0.0 \\
\hline Indetemines & 0.3 & 0.3 & 1.2 & 0.9 & 0.9 & 0.6 & 1.7 & 1.3 & 0.7 & 3.5 & - & - & 2.6 & 0.9 & 1.3 & 3.7 & - & 2.1 & 0.3 & 0.9 & 1.6 \\
\hline Indetemines juv. & 2.6 & 3.9 & 0.3 & 3.2 & 4.8 & 2.6 & 3.4 & 4.7 & 6.7 & 3.2 & 1.9 & 6.3 & 2.9 & 3.2 & 5.2 & 1.7 & 4.5 & 5.8 & 1.9 & 3.4 & 2.2 \\
\hline no. of specimens counted & 303 & 315 & 334 & 316 & 334 & 310 & 298 & 304 & 300 & 284 & 321 & 413 & 350 & 372 & 319 & 297 & 398 & 329 & 318 & 325 & 332 \\
\hline
\end{tabular}

a $=$ living specimens 
Appendix 2. Relative abundance of the species collected in May 1998.

Relative abundance of the species collected in May 1998.

\begin{tabular}{|c|c|c|c|c|c|c|c|c|c|c|c|c|c|c|c|c|c|c|c|c|c|}
\hline \multicolumn{22}{|l|}{ May 1998} \\
\hline no. sample & 2 & 3 & 4 & 5 & 6 & 7 & 8 & 9 & 10 & 16 & 17 & 18 & 19 & 20 & 21 & 22 & 23 & 24 & 25 & 26 & 27 \\
\hline no. specimens $/ 50 \mathrm{~cm}^{3}$ & 180000 & 75000 & 25000 & 35000 & 160000 & 85000 & 75000 & 110000 & 65000 & 8000 & 80000 & 110000 & 35000 & 20000 & 15000 & 10000 & 10000 & 10000 & 25000 & 15000 & 20000 \\
\hline Ammonia parkinsoniana & - & - & - & - & - & - & - & - & - & - & - & - & - & - & - & - & - & - & - & 0.3 & - \\
\hline Amphicaryna scadaris & - & - & - & - & 0.3 & - & - & - & - & - & - & - & - & - & - & - & - & - & - & - & - \\
\hline Angulogerina corgulosa & 1.6 & 1.2 & 0.6 & 0.9 & 1.9 & 1.0 & 1.2 & 3.2 & 15 & 0.9 & 2.2 & 15 & 0.3 & 0.9 & 0.9 & 0.7 & 1.3 & 0.3 & 0.3 & 0.6 & 0.6 \\
\hline Asterigerinass mamilla & 2.0 & 2.7 & 1.5 & 0.9 & 1.6 & 1.0 & 1.8 & 1.4 & 0.3 & 13 & 1.4 & 1.2 & 1.0 & 0.6 & 1.2 & 0.3 & - & 0.3 & 1.3 & 0.3 & - \\
\hline Bolivina pseudoplicata & 2.6 & 4.5 & 5.3 & 3.7 & 39 & 6.0 & 49 & 4.0 & 43 & 1.6 & 4.1 & 7.1 & 8.5 & 35 & 9.2 & 7.0 & 4.2 & 3.3 & 3.8 & 4.3 & 75 \\
\hline Boľvina sp. 1 & 2.9 & 3.9 & 15.2 & 15.7 & 11.9 & 14.0 & 10.0 & 8.6 & 13.1 & 13.8 & 8.7 & 105 & 173 & 193 & 13.8 & 18.2 & 11.3 & 27.8 & 15.4 & 16.1 & 16.0 \\
\hline Bollvina sp. 2 & - & - & - & 0.3 & - & - & 0.3 & - & 0.3 & - & - & 0.6 & - & - & - & - & - & 0.3 & - & - & - \\
\hline Bollvina sp. 3 & 0.7 & 0.3 & 0.3 & - & 0.3 & 03 & - & - & - & - & - & - & - & - & - & - & - & 0.6 & - & 0.3 & - \\
\hline Bollvina spp. juw. & - & - & - & - & - & - & - & - & - & - & 0.3 & - & - & - & - & - & 0.3 & - & - & - & - \\
\hline Brizalina spaghulasa & - & 0.6 & 0.6 & 0.3 & 03 & - & - & 0.6 & 0.6 & 0.3 & - & 0.6 & - & 15 & 0.6 & - & - & - & 0.3 & - & 0.3 \\
\hline Brizalina variabilis & 1.6 & 2.7 & 1.2 & 2.2 & 3.2 & 4.4 & 3.0 & 0.9 & 2.4 & 1.6 & 1.6 & 3.1 & 1.3 & 0.6 & 0.3 & 0.3 & 2.3 & 2.5 & 2.2 & 0.3 & 2.4 \\
\hline Bulimina elegans & 0.7 & 0.3 & 0.3 & 0.6 & - & 0.3 & 0.6 & 0.3 & 0.3 & 1.3 & 0.8 & 0.6 & 1.0 & 1.2 & 0.3 & 1.0 & 1.3 & 4.1 & 1.6 & 1.4 & 0.3 \\
\hline Cassidulina ef. C. crassa & - & - & - & - & - & - & - & - & 1.2 & - & - & - & - & - & - & - & - & - & - & 0.6 & - \\
\hline Cassidulina crassa & 5.2 & 2.7 & 4.7 & 6.8 & 2.3 & 25 & 33 & 4.0 & 3.4 & 0.9 & 3.0 & 3.7 & 3.3 & 3.8 & 55 & 4.6 & 2.6 & 5.0 & 2.9 & 35 & 45 \\
\hline Cassidulina laevigata & 2.0 & 1.5 & 0.3 & 1.2 & 0.6 & 0.3 & 0.3 & 1.7 & 1.2 & 0.6 & 1.4 & 0.6 & 0.7 & 1.2 & 1.8 & - & 0.6 & - & 0.3 & 0.9 & - \\
\hline Cibicides nefugens & 03 & - & 0.6 & - & 03 & - & 03 & - & - & 03 & - & - & - & - & - & - & - & - & - & 03 & - \\
\hline Cornuspira foliacea & - & - & - & - & - & - & - & 0.6 & - & - & - & - & - & - & - & - & - & - & 0.3 & - & - \\
\hline Cornuspira involvens & 0.3 & 0.3 & - & - & - & - & - & - & - & - & 05 & - & - & - & - & - & - & - & - & - & - \\
\hline Cribroelphidam cuvillieri & 0.3 & - & - & - & - & 0.3 & 0.3 & - & - & 0.3 & - & 0.3 & 0.3 & 0.3 & - & - & - & - & - & - & - \\
\hline Cribroelphidiam excavasan & 13 & 4.8 & 3.2 & 2.2 & 1.9 & 2.9 & 33 & 5.2 & 0.9 & 6.6 & 5.4 & 3.1 & 2.6 & 10.8 & 2.8 & 1.0 & 6.1 & 1.9 & 2.9 & 1.7 & 1.2 \\
\hline Cribroelphidian gunteri & - & - & - & - & - & - & - & - & - & 03 & - & - & - & - & - & - & - & - & - & - & - \\
\hline Cribroelphidium mage İanicum & - & 1.8 & 2.6 & 15 & 1.6 & 3.2 & 33 & 1.7 & 1.8 & 75 & 1.4 & 15 & 1.3 & 1.8 & 1.8 & 4.6 & 5.5 & 5.5 & 3.2 & 3.7 & 2.1 \\
\hline Cribroelphidiam williamsoni & 0.3 & 1.5 & 0.6 & 03 & 03 & 0.3 & 03 & 0.9 & 0.6 & 0.3 & 0.3 & 1.9 & 0.7 & 0.6 & 0.3 & 0.3 & - & - & - & 0.6 & 03 \\
\hline Cribrononion gerhi & 1.0 & 1.5 & 1.5 & 15 & 0.6 & 1.6 & 15 & 1.1 & 1.2 & 0.9 & 05 & 0.9 & 1.3 & 1.8 & 0.6 & 0.3 & 0.6 & - & 0.6 & 0.3 & 1.2 \\
\hline Cribrononion ef. C. gerthi & - & - & - & - & - & - & - & - & - & - & - & - & - & - & - & - & 0.3 & - & - & - & - \\
\hline Cribrostomodes jeffreysï & 0.7 & 0.3 & - & - & 1.0 & - & - & 2.3 & 0.9 & - & 1.6 & 0.6 & 1.0 & - & - & 0.3 & 0.3 & 0.3 & 0.3 & 0.6 & 0.9 \\
\hline Deuterammina eddyssonensis & - & - & - & - & 2.6 & 0.6 & - & 0.6 & 0.9 & 0.6 & 1.1 & 1.2 & 0.3 & 0.3 & - & 0.7 & 0.6 & 0.6 & 0.6 & 1.2 & - \\
\hline
\end{tabular}




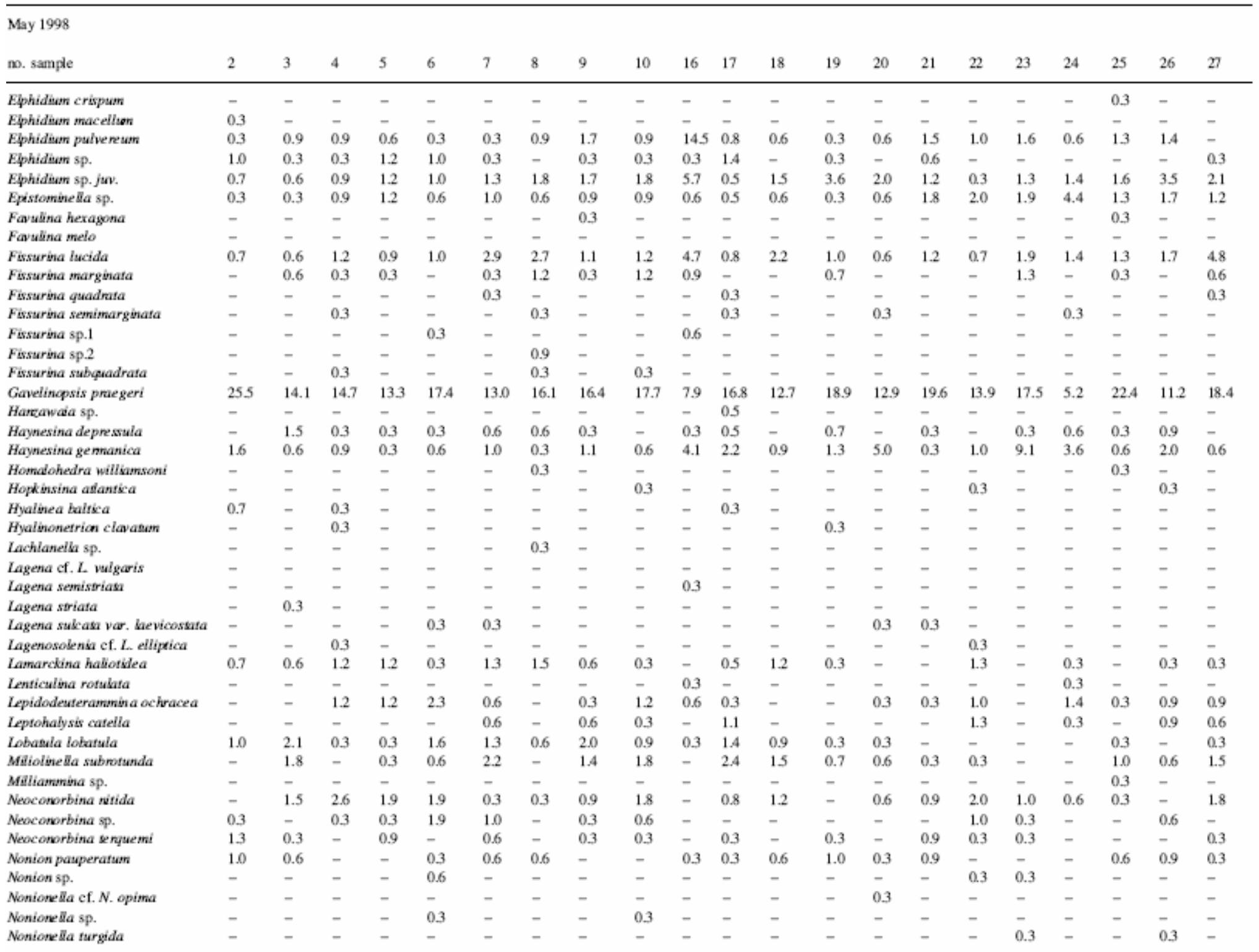


May 1998

$\begin{array}{llllllllllllllllllllll}\text { no. sample } & 2 & 3 & 4 & 5 & 6 & 7 & 8 & 9 & 10 & 16 & 17 & 18 & 19 & 20 & 21 & 22 & 23 & 24 & 25 & 26 & 27\end{array}$

Palliolatela sp.

Pallolas Ila orbignyane

Pargfissurina sp.

Paratrochammina ef. P. haynesi

$\begin{array}{llllll}\text { Pardrochammina sp. } & - & 0.3 & - & 0.3 & - \\ \text { Patelina corrugda } & 1.0 & 0.3 & 0.6 & 0.6 & 0.6\end{array}$

$\begin{array}{llllll}\text { Planorbulina medterranensis } & 2.0 & 7.2 & 3.5 & 0.3 & 32\end{array}$

Planorbulina medterranensis juv. $15.0 \quad 13.2 \quad 8.8 \quad 13.6 \quad 9.6$

Pseudonanion atbaticum

Quingueboculina berthelatiana

Quinguebedina of $e$ anatnata

Quingueboudina lata

Quingue boctina seminda

Quingueboculina spo.

Quingue boculina ste IIigera

Quingue boculina trigonula

Remaneicella gonzalezi

Reophax ef. R. arcica

Reophax nana

Rosolina of. $R$. vilardeboana

Rosdina globularis

Rosalina sp.

Rotdiella sp.

Rubratella insenneds

Signavirgulina sp.

Signomorhina williamsoni

Siphonaperta contcrta

Spirillina vivipara

Spiroloculina depressa

Spiroplectinella earlandi

Stainforthia of. S. concava

Stainforthia fisifonnis

Svratkina tuberculata

Textubaria truncata

Trochammina sp.

Wiesnerella auniculata

$\begin{array}{lllllllll}13.6 & 9.6 & 3.2 & 10.9 & 10.1 & 9.1 & 4.7 & 9.2 & 1.2\end{array}$

$\begin{array}{llllllllllllllll}3.2 & 10.9 & 10.1 & 9.1 & 4.7 & 9.2 & 14.2 & 8.0 & 1.2 & 0.3 & - & 0.6 & - & 2.2 & 0.9 & 0.6\end{array}$

Undetermined juveniles

0.3

$\begin{array}{lll}0.6 & 0.3 & 0.3\end{array}$

Undetermined

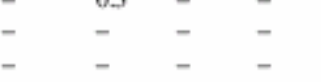

-

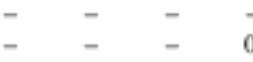$$
-
$$

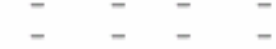

$\begin{array}{lllllllll}8.1 & 7.3 & 8.9 & 4.6 & 5.2 & 2.2 & 9.0 & 5.2 & 10.2 \\ 0.3 & 0.9 & - & 10 & 16 & 2.2 & - & 5.5 & -\end{array}$


Appendix 3. Relative abundance of the species collected in September 1998.

Relative abundance of the species collected in September 1998.

September 1998

\begin{tabular}{|c|c|c|c|c|c|c|c|c|c|c|c|c|c|c|c|c|c|c|}
\hline no. sample & 1 & 2 & 3 & 4 & 5 & 6 & 7 & 8 & 9 & 10 & 11 & 12 & 13 & 14 & 15 & 17 & 18 & coast \\
\hline no. speciments $/ 50 \mathrm{~cm}^{3}$ & 30000 & 45000 & 80000 & 24000 & 30000 & 2000 & 2000 & 54000 & 26000 & 10000 & 33000 & 16000 & 26000 & 21000 & 40000 & 9000 & 9000 & 10000 \\
\hline no. species & 57 & 73 & 63 & 68 & 60 & 44 & 51 & 58 & 49 & 55 & 54 & 48 & 57 & 56 & 58 & 48 & 43 & 31 \\
\hline Ammabaculites exiguus & - & - & - & - & - & - & 0.4 & - & - & - & - & - & - & - & - & - & - & - \\
\hline Ammonia beccarii & - & 0.5 & 0.0 & - & - & - & - & - & - & - & - & - & - & - & - & - & - & 19 \\
\hline Ammonia tepida & - & - & 0.4 & 0.6 & 0.6 & 0.6 & 3.0 & 1.2 & 1.1 & 1.2 & - & - & 0.1 & 0.1 & - & - & - & - \\
\hline Amphycorina scalaris & - & - & - & - & - & - & - & - & - & 0.0 & - & - & - & - & - & - & - & - \\
\hline Angulogerina angulas a & 5.6 & 3.1 & 1.7 & 3.4 & 2.1 & 1.9 & 0.4 & 3.0 & 2.2 & 1.2 & 0.6 & 5.6 & 2.4 & 1.9 & 1.6 & 3.6 & 1.0 & 4.8 \\
\hline Asterigerinat a mamilla & 2.5 & 1.6 & 3.9 & ${ }^{4} 3.7$ & 1.6 & 0.6 & 2.6 & 0.7 & 1.2 & 3.0 & 1.8 & 1.7 & 2.0 & 0.1 & 2.1 & 3.0 & 1.2 & 19 \\
\hline Asterotrochammina sp. & 0.6 & 0.0 & 0.0 & - & 0.0 & - & - & - & 0.1 & - & 0.0 & - & - & 0.0 & 03 & - & - & - \\
\hline Aubignyna planidorsa & - & - & - & 0.6 & - & - & - & - & - & 0.6 & - & - & 0.6 & - & 19 & 1.2 & 0.7 & - \\
\hline Bolivina diffomis & 1.4 & 3.5 & 5.6 & 3.2 & 1.3 & 3.2 & 0.8 & 0.6 & 2.8 & 1.8 & 6.6 & 5.8 & 5.4 & 1.9 & 3.4 & 2.4 & 3.9 & 0.0 \\
\hline Bolivina pseudoplicata & 1.1 & 1.9 & 2.5 & 4.2 & 6.4 & 9.5 & 1.3 & 7.2 & 6.1 & 9.0 & 4.1 & 11.2 & 12.6 & 1.9 & 5.8 & 8.5 & 2.1 & - \\
\hline Bolivina sp.1 & 19 & 0.3 & 0.8 & - & 1.9 & 10.1 & 2.2 & 5.4 & 5.5 & 8.4 & 3.5 & 3.9 & 7.8 & 6.5 & 3.7 & 3.0 & 2.1 & - \\
\hline Bolivina sp. 2 & - & - & - & - & 0.2 & - & - & - & - & - & - & - & - & - & - & - & - & - \\
\hline Bolivina spp. & 2.2 & - & 1.7 & 1.8 & 2.7 & 5.0 & 3.4 & 2.4 & 2.2 & 1.8 & 2.4 & 1.7 & 2.4 & 1.8 & 23 & 3.0 & 2.1 & - \\
\hline Brizalina spathulata & - & 0.8 & 0.4 & 0.6 & 3.8 & 0.6 & 1.3 & 1.2 & 0.6 & 1.2 & 0.0 & 1.1 & 0.1 & - & 1.4 & - & 0.3 & 0.0 \\
\hline Brizalina variabilis & 1.7 & 1.3 & 1.5 & 4.2 & 1.9 & 4.4 & 1.3 & 6.6 & 6.6 & 4.8 & 0.6 & 0.7 & 1.8 & 4.2 & 4.7 & 1.8 & 4.4 & - \\
\hline Bulimina elegans & 0.0 & 0.5 & 0.3 & 0.7 & 1.3 & 0.0 & 0.4 & 0.0 & 1.2 & 1.3 & 0.1 & 0.1 & 0.7 & 0.2 & 0.5 & 1.9 & 1.1 & 3.8 \\
\hline Bulimina elongata & - & 0.0 & 0.0 & - & - & - & 0.4 & - & - & - & - & - & 0.0 & - & - & - & 0.4 & - \\
\hline Bulimina marginata & 19 & 0.5 & 0.3 & 1.0 & 0.3 & 0.6 & 1.7 & 0.6 & 0.9 & 2.4 & 1.2 & 1.8 & 0.1 & - & 1.4 & 0.8 & 0.0 & 1.0 \\
\hline Buliminella elegantissima & - & - & - & 20 & - & 0.6 & - & 0.6 & - & 0.0 & 0.6 & - & - & - & - & - & - & - \\
\hline Cassidulina crassa & 3.6 & 0.8 & 2.9 & 2.1 & 3.2 & 3.2 & 0.9 & 1.8 & 3.9 & 6.0 & 4.1 & 4.5 & 2.4 & 4.8 & 3.7 & 3.0 & 1.4 & 1.0 \\
\hline Cassidulina laevigata & 1.4 & 0.0 & 1.3 & 2.5 & 0.2 & - & 0.4 & 0.1 & 0.1 & 0.1 & 0.6 & 1.2 & 0.6 & - & 09 & 1.2 & - & 1.0 \\
\hline Cibicides fletcheri & - & - & - & - & - & - & - & - & - & - & - & - & 0.1 & 0.6 & - & 0.2 & 0.4 & - \\
\hline Cibicides refulgens & - & - & - & - & 0.2 & - & - & - & - & 0.1 & - & - & - & - & - & - & - & - \\
\hline Cribroelphidium cuvillier & - & - & - & 0.1 & - & - & - & - & - & - & - & 0.1 & - & - & - & - & - & - \\
\hline Cribroelphidium excavatum & 7.7 & 96.4 & ${ }^{\mathrm{s}} 10.0$ & 2.5 & 963 & ${ }^{a} 17.3$ & 23.2 & 2.0 & ${ }^{2} 6.9$ & 8.9 & 95.3 & 4.7 & ${ }^{2} 6.6$ & 97.6 & "6.4 & 5.7 & ${ }^{\mathrm{a}} 1 . .7$ & *3.8 \\
\hline $\begin{array}{l}\text { Cribroelphidium } \\
\text { magellanicum }\end{array}$ & 0.0 & 0.0 & 0.3 & 1.8 & 2.6 & 19 & ${ }^{2} 8.5$ & 1.5 & 0.7 & 2.4 & 1.2 & 0.7 & 1.2 & 3.1 & 1.6 & 0.6 & a 1.9 & - \\
\hline Cribroelphidium williamsoni & - & 0.0 & 0.0 & $0 . t$ & - & 0.6 & - & 1.2 & - & - & - & 1. & 0.0 & 0. & 1. & 1.3 & 0.8 & - \\
\hline Cribrononion gerthi & 0.6 & 0.3 & 1.5 & 0.4 & 0.8 & 0.6 & 0.8 & 1.9 & 1.1 & 0.6 & 2.5 & 3.1 & 2.4 & 1.3 & 13 & 2.7 & 0.7 & - \\
\hline Cribrostomoides jeffreysii & 0.8 & 0.8 & 0.7 & 1.0 & 0.8 & 1.9 & 0.8 & 0.6 & 1.7 & 1.8 & 1.2 & 1.7 & 1.2 & 1.2 & 03 & 0.7 & 0.7 & 0.0 \\
\hline Cycloforina cf. C.stalkeri & - & - & - & - & - & - & - & - & - & - & - & 0.6 & - & - & - & - & - & - \\
\hline Cycloforina sp.1 & 0.0 & 0.0 & - & 0.6 & - & 0.6 & 0.9 & - & - & - & - & - & - & - & - & - & - & - \\
\hline Cycloforina sp. 2 & - & - & - & - & - & - & 0.4 & 0.6 & - & - & - & - & - & - & - & - & - & - \\
\hline Cyclogira sp. & 0.0 & 0.8 & 0.3 & 0.6 & 0.2 & - & - & 0.6 & 0.6 & - & 0.6 & - & 0.0 & 0.1 & 0.0 & 0.4 & 0.8 & - \\
\hline Deuterammina sp & 0.6 & 0.3 & 0.0 & 0.1 & - & 2.5 & 0.4 & 0.6 & 0.6 & - & 2.4 & - & 0.6 & 2.9 & 1.6 & 1.2 & 0.3 & - \\
\hline
\end{tabular}


September 1998

\begin{tabular}{|c|c|c|c|c|c|c|c|c|c|c|c|c|c|c|c|c|c|c|}
\hline no. sample & 1 & 2 & 3 & 4 & 5 & 6 & 7 & 8 & 9 & 10 & 11 & 12 & 13 & 14 & 15 & 17 & 18 & coast \\
\hline Discorbinella bertheloti & 0.0 & - & - & 0.6 & - & - & - & - & 0.6 & - & 0.1 & 0.6 & 0.1 & - & 0.6 & 0.2 & - & - \\
\hline Edentostomina sp. & - & 0.3 & - & 0.0 & - & - & - & 0.0 & - & - & - & - & - & - & - & - & - & - \\
\hline Eggerelloides scabnus & 0.8 & 2.0 & 1.0 & ${ }^{2} 0.4$ & - & - & ${ }^{2} 0$ & - & - & - & 0.1 & - & 0.0 & 0.0 & ${ }^{2} 0.3$ & - & - & - \\
\hline Elphidium aculeatum & - & 0.3 & 0.0 & - & 0.2 & 0.0 & 0.4 & 0.1 & - & - & - & 0.6 & 0.0 & 0.0 & - & - & - & 0.0 \\
\hline Elphidium crispum & - & - & - & - & - & - & - & - & - & - & - & - & - & - & - & - & - & 1.9 \\
\hline Elphidium macellum & - & 0.0 & - & - & 0.6 & - & - & - & - & - & - & - & 0.1 & - & - & - & - & - \\
\hline Elphidium pulvereum & 0.3 & 1.8 & 1.4 & 0.5 & ${ }^{2} 4.3$ & 0.0 & ${ }^{2} 5.0$ & 0.5 & 2.3 & 1.5 & 0.4 & ${ }^{\mathrm{a}} 1.2$ & 3.3 & ${ }^{2} 0.9$ & ${ }^{\mathrm{a}} 1.8$ & ${ }^{\mathrm{a}} 10.8$ & ${ }^{\mathrm{a}} 18.7$ & 3.8 \\
\hline Epistominella sp. & - & - & - & - & - & - & - & - & - & - & - & 1.1 & - & - & - & - & - & - \\
\hline Favulina hexagona & - & 0.0 & 0.0 & 0.1 & 0.0 & - & - & 0.1 & 0.1 & - & 0.7 & - & - & 0.1 & 0.2 & - & 0.0 & - \\
\hline Favulina lineata & 0.0 & 0.0 & 0.0 & - & 0.0 & - & 0.0 & - & - & - & - & - & 0.6 & - & 0.5 & - & - & - \\
\hline Favulina melo & - & 0.0 & - & - & 0.0 & - & - & 0.0 & - & - & - & - & 0.0 & 0.0 & - & - & - & - \\
\hline Favulina squamosa & 0.0 & 0.0 & - & 0.0 & - & - & - & 0.0 & - & - & 0.0 & 0.1 & - & - & - & - & - & - \\
\hline Fissurina lucida & - & 0.0 & 0.0 & 1.2 & 1.0 & 1.3 & 0.9 & 0.6 & 1.7 & 2.4 & - & 1.1 & 0.0 & 0.6 & 0.2 & 0.7 & 0.3 & 0.0 \\
\hline Fissurnina marginata & - & - & - & - & - & - & - & - & - & - & - & 0.6 & - & 0.6 & - & 0.6 & - & - \\
\hline Fissurina quadrata & - & - & - & - & - & - & - & - & - & - & - & - & - & - & 0.5 & - & - & - \\
\hline Fissurina spp. & - & 0.5 & 0.4 & - & 1.9 & 0.6 & - & 0.6 & - & 0.6 & 1.2 & 1.1 & 1.8 & 1.2 & 0.9 & 3.6 & 0.3 & 0.0 \\
\hline Gavelinopsis praegeri & 17.5 & 8.2 & 17.5 & 20.8 & 13.0 & 9.5 & 3.4 & 9.9 & 18.6 & 10.3 & 17.2 & 12.5 & 11.7 & 14.0 & 7.2 & 9.9 & 5.6 & 4.8 \\
\hline Glabratella cf. G. baccata & - & - & - & - & 0.0 & 1.3 & - & 1.2 & 1.7 & - & - & - & 0.6 & - & 0.5 & 0.6 & - & - \\
\hline Glabulina gibba & - & - & 0.0 & - & - & - & - & - & - & - & 0.0 & - & - & - & - & - & - & - \\
\hline Homalohedra williamsoni & - & 0.0 & 0.0 & - & 0.0 & - & - & 0.1 & 0.1 & - & 0.0 & 0.1 & 0.0 & 0.0 & 0.2 & - & - & - \\
\hline Haynesina depressula & - & a 10.8 & - & 0.6 & ${ }^{\mathrm{a}} 0$ & 0.8 & 1.2 & 0.8 & 0.1 & - & 0.6 & - & - & 0.7 & ${ }^{2} 0.3$ & 20.9 & 4.0 & - \\
\hline Haynesina gemanica & 0.0 & 1.0 & 0.3 & ${ }^{2} 0.4$ & 0.0 & ${ }^{2} 0.6$ & 8.6 & 0.1 & ${ }^{2} 0.3$ & 0.3 & 0.3 & a 1.5 & 0.1 & 1.3 & 0.2 & 3.4 & ${ }^{\mathrm{a}} 12.3$ & - \\
\hline Hyalinonetrion sp. & 0.0 & 0.0 & 0.0 & 1.2 & 0.0 & 0.6 & 0.9 & - & 0.1 & - & - & 0.1 & - & - & 0.2 & 0.1 & - & - \\
\hline Lachlanella sp. & 0.0 & - & - & - & - & - & - & - & - & - & - & - & - & - & - & - & - & - \\
\hline Lagena laevis & - & 0.0 & 0.0 & 0.6 & 0.0 & - & - & 0.7 & - & 0.1 & 0.0 & 0.6 & 0.6 & - & - & - & - & - \\
\hline Lagena semistriata & 0.3 & 0.0 & 0.3 & 0.0 & - & - & - & - & 0.1 & - & 0.0 & 0.1 & 0.0 & - & - & - & - & 0.0 \\
\hline Lagena striata & 0.0 & 0.5 & 0.6 & 0.0 & 0.2 & 0.1 & - & - & - & 0.1 & 0.1 & - & 0.1 & 0.2 & 0.3 & 0.1 & - & 0.0 \\
\hline $\begin{array}{l}\text { Lagena sulcata var. } \\
\text { laevicostata }\end{array}$ & 0.0 & - & 0.0 & 0.3 & - & - & - & 0.0 & - & - & - & - & - & 0.6 & - & - & - & - \\
\hline Lagenosolenia lagenoides & - & - & 0.4 & - & - & - & - & - & - & 0.6 & - & - & 0.0 & 0.6 & - & 0.6 & - & - \\
\hline Lamarckina haliotidea & - & - & 0.4 & 0.6 & - & - & 0.4 & 0.6 & 0.6 & 0.6 & 2.4 & 0.6 & 1.2 & 0.6 & - & 0.6 & 0.7 & 0.0 \\
\hline Lenticulina rotulata & - & 0.5 & 0.0 & 0.0 & 0.0 & - & - & 0.1 & - & 0.6 & - & 0.0 & - & - & - & - & - & - \\
\hline $\begin{array}{l}\text { Lepidodeuterammina } \\
\text { ochracea }\end{array}$ & 0.6 & 0.3 & 0.0 & 0.7 & 0.2 & 1.3 & 0.9 & 2.5 & 0.6 & 1.8 & 0.6 & 0.6 & 1.2 & 0.6 & 0.6 & 0.6 & 0.7 & - \\
\hline Leptohalysis catella & - & - & - & - & 0.6 & 0.6 & - & - & 0.1 & - & 0.1 & - & 0.0 & - & 0.6 & - & - & - \\
\hline Labatula lobatula & 24.6 & 20.2 & 15.5 & ${ }^{\mathrm{a}} 10.1$ & 17.3 & as.3 & 5.4 & 15.3 & 11.1 & 5.7 & 11.5 & 6.2 & ${ }^{\mathrm{a}} 14.2$ & 12.0 & ${ }^{a} 17.5$ & 6.3 & 5.4 & 54.8 \\
\hline Massilina secans & - & 0.5 & - & - & - & - & - & 0.1 & - & - & - & - & - & - & - & - & - & 1.0 \\
\hline Miliolinella abliquinodus & - & - & - & - & - & - & - & - & - & - & - & - & - & 0.6 & - & - & - & - \\
\hline Miliolinella subrotunda & 0.0 & 0.8 & 0.3 & 0.9 & 0.6 & - & 0.4 & 1.8 & 0.7 & 0.1 & 0.7 & - & - & 0.6 & 0.2 & - & - & - \\
\hline
\end{tabular}


September 1998

\begin{tabular}{|c|c|c|c|c|c|c|c|c|c|c|c|c|c|c|c|c|c|c|}
\hline no. sample & 1 & 2 & 3 & 4 & 5 & 6 & 7 & 8 & 9 & 10 & 11 & 12 & 13 & 14 & 15 & 17 & 18 & coast \\
\hline Milliammina sp. & - & 0.0 & - & - & - & - & - & - & - & - & - & - & - & - & - & - & - & - \\
\hline Neoconorbina milletti & - & - & - & - & - & - & - & - & - & - & - & - & - & 0.6 & - & - & - & - \\
\hline Neoconorbina nitida & 0.3 & 0.5 & 0.3 & 2.5 & 0.0 & 1.3 & 0.9 & 1.8 & 2.8 & 1.2 & 1.8 & 4.5 & 1.9 & 4.1 & 1.6 & 1.8 & 0.3 & - \\
\hline Neoconorbina terquemi & 0.3 & 0.0 & - & - & - & - & - & - & - & - & - & - & - & - & - & - & - & - \\
\hline Nonion pauperatum & 0.0 & - & 0.4 & - & 1.3 & - & 0.4 & 0.6 & - & 0.6 & 0.6 & 0.6 & - & - & - & - & 0.0 & - \\
\hline Nonionella cf. $N$. turgida & - & - & - & - & - & - & - & - & - & - & - & - & - & - & 0.2 & - & - & - \\
\hline Nonionella opima & 0.0 & - & - & 0.0 & - & - & - & - & - & 0.6 & - & - & - & - & 0.5 & - & - & - \\
\hline Palliolatella orbignyana & 0.8 & 0.5 & 0.3 & 2.3 & 1.9 & 0.1 & 0.8 & 1.3 & 1.3 & 0.1 & 1.4 & 0.4 & 0.7 & 1.4 & 1.7 & 0.1 & 0.4 & 0.0 \\
\hline Parafissurina sp. & - & - & - & 1.8 & - & - & - & - & 0.6 & 1.2 & 0.1 & 0.1 & - & - & 0.2 & - & - & - \\
\hline $\begin{array}{l}\text { Paratrochammina cf. } P \text {. } \\
\text { haynesi }\end{array}$ & 0.0 & - & - & 0.6 & - & - & - & - & - & - & - & - & 0.1 & 0.6 & - & - & - & - \\
\hline Paratrochammina sp. & - & - & - & - & - & - & - & - & - & - & - & - & 0.6 & - & - & 0.1 & - & - \\
\hline Patellina comugata & 0.8 & 0.5 & 1.1 & 0.0 & 0.0 & 0.6 & 0.4 & 2.5 & 1.1 & 2.4 & 1.8 & 0.6 & 0.1 & - & 1.1 & - & 0.0 & - \\
\hline Planorbulina mediterranensis & 7.8 & 19.2 & 7.8 & 4.3 & 6.2 & 0.1 & 4.1 & 2.4 & 0.7 & 0.3 & 1.4 & ${ }^{2} 0.8$ & 0.6 & 2.6 & 4.4 & 0.1 & 1.2 & 1.0 \\
\hline Polymomhina sp. & - & - & - & 0.0 & - & - & - & - & - & - & - & - & - & - & - & - & - & - \\
\hline Pracerolagena implicata & - & - & - & 0.0 & - & - & - & - & - & - & - & - & - & - & - & - & - & - \\
\hline Pseudononion at lanticum & - & ${ }^{a} 0$ & 0.0 & 0.0 & - & 1.3 & ${ }^{2} 0.4$ & - & - & - & - & - & - & 0.6 & 0.5 & 0.6 & - & - \\
\hline Pseudatriloculina sp. & - & - & - & - & - & - & - & - & - & - & - & - & - & - & - & 0.1 & - & - \\
\hline Pyramidula cates byi & - & - & - & - & - & - & - & - & - & 0.0 & - & - & - & - & - & - & - & - \\
\hline Quinqueloculina laevigata & - & - & - & - & - & - & - & - & - & - & - & - & - & - & 0.2 & - & - & - \\
\hline Quinqueloculina lamarckiana & - & 0.3 & - & - & - & - & - & - & - & - & - & - & - & 0.1 & - & - & - & - \\
\hline Quinqueloculina lata & - & 0.0 & - & 0.0 & 0.6 & - & 0.4 & 0.6 & - & - & 0.6 & - & 0.6 & - & - & 0.6 & 0.3 & 0.0 \\
\hline Quinqueloculina seminula & 0.0 & 0.3 & 0.4 & 0.6 & - & - & 0.4 & 0.6 & 0.1 & 0.6 & 1.2 & - & - & - & 0.5 & 1.3 & 1.2 & 1.0 \\
\hline Quinqueloculina spp. & 0.6 & 0.5 & 0.4 & 0.6 & - & 1.3 & 1.3 & 0.1 & - & 0.6 & 0.6 & - & - & 0.1 & 0.6 & - & 1.9 & 3.8 \\
\hline Quinqueloculina stelligera & 0.0 & 0.5 & 0.3 & - & - & - & - & - & 0.6 & 0.6 & 0.6 & - & - & ${ }^{a} 13$ & - & - & - & 0.0 \\
\hline Rectuvigerina phlegeri & - & 0.0 & 0.3 & - & - & - & - & - & - & - & - & - & - & - & - & - & - & - \\
\hline Remaneica plicata & 0.6 & 0.0 & 0.0 & 0.0 & 0.6 & - & - & 0.1 & 0.1 & 0.1 & - & 0.6 & - & 0.0 & 0.5 & - & 0.8 & - \\
\hline Remaneicella gonzalezi & - & 0.0 & - & - & - & - & - & - & - & - & - & - & - & - & - & - & - & - \\
\hline Reophax ? sp. & 0.6 & - & - & - & - & - & 0.4 & - & - & - & 0.6 & - & - & - & - & - & - & - \\
\hline Reophax nana & 0.6 & 0.8 & 0.4 & 0.0 & 0.0 & 1.3 & 0.9 & 1.2 & - & - & 0.0 & - & - & 0.6 & - & - & - & - \\
\hline Rasalina anglica & 0.3 & - & - & - & 0.2 & - & - & - & - & - & - & - & - & 0.0 & - & - & - & - \\
\hline Rosalina bradyi & 0.3 & 0.0 & 1.3 & - & 0.6 & - & 0.4 & - & 0.1 & 0.6 & - & 0.0 & 0.7 & - & 0.2 & - & - & - \\
\hline Rosalina $\mathrm{cf}$. vilardeboana & 0.3 & 0.0 & 0.3 & 0.1 & - & - & - & - & - & 0.1 & 0.6 & - & - & - & 0.2 & 0.1 & - & 2.9 \\
\hline Rosalina globularis & 1.1 & 1.5 & 2.1 & 0.6 & 4.2 & 1.3 & 0.4 & 1.9 & 0.1 & 1.2 & 2.5 & 4.6 & 3.6 & 1.3 & 19 & 3.3 & 1.4 & 1.0 \\
\hline Rotaliella sp. & - & - & - & - & - & - & - & - & - & - & - & - & - & - & 0.9 & - & - & - \\
\hline Rubratella intemedia & - & - & - & - & 0.6 & - & - & - & - & 0.6 & - & - & - & 0.6 & - & 0.6 & - & - \\
\hline Sigmoilina sp. & - & - & - & - & 0.0 & - & - & - & - & - & - & - & - & - & - & - & - & - \\
\hline Sigmomomhina williamsoni & - & 0.0 & - & 0.6 & - & - & 0.4 & - & 0.0 & - & - & - & 0.6 & - & - & - & - & - \\
\hline
\end{tabular}


Appendix C (continued)

September 1998

\begin{tabular}{|c|c|c|c|c|c|c|c|c|c|c|c|c|c|c|c|c|c|c|}
\hline no. sample & 1 & 2 & 3 & 4 & 5 & 6 & 7 & 8 & 9 & 10 & 11 & 12 & 13 & 14 & 15 & 17 & 18 & coast \\
\hline $\begin{array}{l}\text { Siphonaperta cf. anguina } \\
\text { arenata }\end{array}$ & - & - & - & 0.0 & - & - & - & - & - & - & - & - & - & - & - & - & - & - \\
\hline Siphonaperta aspera & - & 0.0 & - & - & - & - & - & - & - & - & - & - & - & - & - & - & - & - \\
\hline Siphonaperta sp. & - & - & - & 0.0 & - & - & - & - & - & - & - & - & - & - & - & - & - & - \\
\hline Spiroloculina depressa & - & - & - & - & - & - & - & 0.0 & - & - & - & - & - & - & - & - & - & - \\
\hline Spiroloculina dilatata & 0.3 & 0.0 & - & - & - & - & - & - & - & - & - & - & - & - & 0.5 & - & - & - \\
\hline Spiroplectinella earlandi & 0.6 & 0.3 & - & 0.7 & 0.0 & - & 2.1 & - & 0.6 & 0.6 & - & - & - & 0.7 & - & - & - & - \\
\hline Stainforthia fus iformis & 0.0 & 0.0 & 0.8 & 0.0 & 0.0 & 0.6 & 13 & 1.8 & 0.6 & 1.2 & 1.2 & 0.6 & 0.6 & 0.6 & 1.9 & - & 0.7 & - \\
\hline Svratkina tuberculata & - & - & - & - & - & - & - & - & - & - & - & - & 0.6 & - & - & - & - & - \\
\hline Textularia truncata & 6.7 & 3.4 & 9.3 & 9.4 & 5.4 & 3.8 & 1.7 & 8.9 & 7.0 & 6.1 & 9.1 & 8.0 & 3.1 & 9.6 & 4.4 & 5.4 & 1.8 & 4.8 \\
\hline Triloculina trigonula & - & 0.0 & - & 0.0 & - & - & - & - & - & - & - & - & - & - & - & - & - & - \\
\hline Triloculina williamsoni & 0.8 & 0.8 & - & 0.0 & - & - & - & 0.6 & - & 0.1 & 0.6 & - & - & - & - & 0.6 & - & - \\
\hline Turrispirillina sp. & - & 0.0 & 0.0 & - & 0.0 & 0.6 & - & - & - & - & - & - & - & - & - & - & - & - \\
\hline Vasicastella sp. & - & - & - & - & 0.0 & - & - & - & - & - & - & - & - & - & - & - & - & - \\
\hline no. of specimens counted & 313 & 347 & 354 & 314 & 300 & 306 & 308 & 341 & 353 & 349 & 359 & 381 & 376 & 365 & 385 & 358 & 334 & 315 \\
\hline
\end{tabular}

a living specimens 